This report has been reproduced directly from the best available copy.

Available to DOE and DOE contractors from the Office of Scientific and Technical Information, P.O. Box 62, Oak Ridge. TN 37831; prices available from (615) 576-8401, FTS 626-8401.

Available to the public from the National Techrical Information Service, U.S. Department of Commerce, 5285 Port Royal Rd., Springfield, VA 22161. 
Business

Planning

Scientists

Engineers

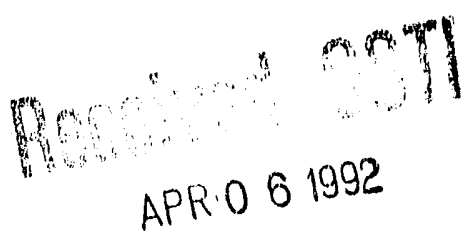

(1..............

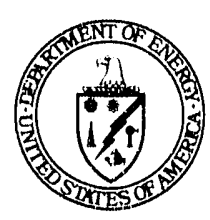

prepared for

the United States Department of Energy

by

(c) Dawnbreaker, May 1991

Jenny C. Servo, Ph.D.

Paul D. Hauler

Under Grant No. DE-FG05-89ER 80688

IER

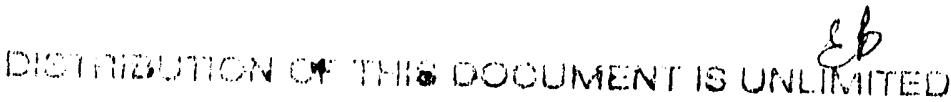




\section{FIRST EDITION}

Book design, figures and tables by Blair Hornbuckle.

Illustrations by John Kastner and John K. Servo, (c) Dawnbreaker 1988, 1990.

The authors have granted to the U.S. Department of Energy the right to publish this document. No part of this book may be reproduced by anyone else, in any form, or by any means without the express written consent of the authors. 


\section{ACKNOWLEDGEMENTS}

This book is part of an evolving vision that started with Dr. Sam Barish and Mr. Ron Toms of the US Department of Energy and which has grown to encompass Dawnbreaker and numerous SBIR companies. The need for assistance for companies approaching Phase III was recognized in the late ' 80 s by Dr. Barish and Mr. Toms. They championed a pilot project to provide commercialization assistance to companies that had received Phase II funding through the US Department of Energy's Small Business Innovation Research program. It has been our privilege to develop the Commercialization Assistance program and to become a part of this vision.

We would like to thank Mr. Frank Ferrell, Mr. Ray Barnes, Mr. Bernard Rock, and Dr. James Coleman for their support. We would also like to express our gratitude to Dr. Walter Polansky and Dr. Duane Barney for the many useful suggestions they provided. Ms. Kay Etzler, Ms. Gerry Washington and her staff gave help that was invaluable. Thank you! Lastly, we would like to thank the Principal Investigators of the SBIR companies with which we have worked. Your questions helped us to develop a workbook which we hope will be of unique assistance. 


\section{PREFACE}

Business Planning for Scientists and Engineers is a combination text/workbook intended for use by individuals and firms having received Phase II SBIR funding (Small Business Innovation Research). It is used to best advantage in combination with other aspects of the Commercialization Assistance Project developed by Dawnbreaker for the U.S. Department of Energy.

Although there are many books on the market which indicate the desired contents of a business plan, there are none which clearly indicate how to find the needed information. This book focuses on the how of business planning: how to find the needed information; how to keep yourself honest about the market potential; how to develop the plan; how to sell and use the plan.

The most basic requirements for business plan development are time and human resources. Our experience with business planning probably echoes that of most small companies.You need the plan when you have the least resources available to develop it. After all, time spent in developing the business plan competes with time you could be using to meet development milestones, sell your product/service, or do other productive work. Business matters always seem to be more urgent and pressing than developing the plan. In the Chapter entitled "Benchmarking your starting point," attention is given to project planning to increase the likelihood that you successfully make it through this program and emerge with a completed business plan.

Business planning is usually described as a linear process. However, experience clearly indicates that it is iterative in nature. It starts with the plan the entrepreneur already has in his or her head. When asked, any entrepreneur can tell you what his technology or product is; who he thinks will buy it; how many he will sell; and what the cost of development or production will be. However, his answers are usually conjecture. For the most part, little data collection has actually gone into verifying the assumptions that this information represents. That plan, that starting point is, however, important. It represents the entrepreneur's first "plan," and the drum to which he or she is marching. Through a gradual process of adding more facts, that plan begins to shift. One organizing theme throughout this book is to move from conjecture to certitude, from intuition to facts. This is done in an iterative fashion as each new element of information that you uncover has implications for the rest. The purpose of this book is to accelerate the rate at which those initial assumptions change.

Business Planning for Scientists and Engineers is not intended to be an academic treatise, but a useful document that will guide you through the business planning process. It is designed for companies developing a technology or product that do NOT have a business plan in hand or that wish to create a new one. Most companies that have existing business plans create them for a specific purpose (usually obtaining funding) and then quickly set them aside, rather than using them to guide their business decisions. A business plan should be a living document, referred to frequently, and modified on an annual basis as you learn more about your market and the dynamic conditions in which businesses function. 


\section{CONTENTS}

Preface vii *

\section{SECTION 1: TEXT}

\section{Chapter 1: Commercialization Process}

Terminology

Perspectives in the Commercialization Process ................................................ 1

Players in the Commercialization Process ..................................................... 5

Developing and Finding the Commercialization Team ................................... 8

Summary and Conclusions ......................................................................... 10

\section{Chapter 2: Potential Funding Sources}

Getting Close to the Customer .................................................................... 15

Equity Investment: Venture Capitalists and Business Angels .............................18

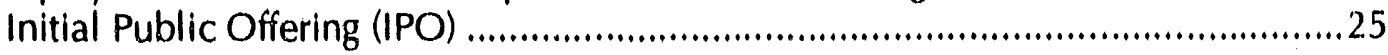

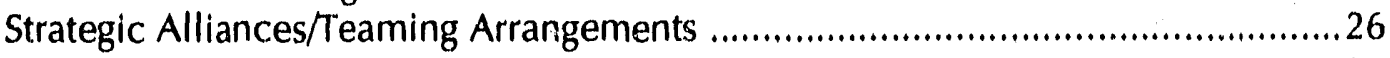

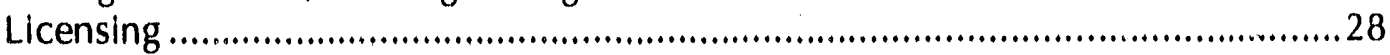

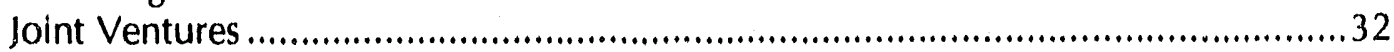

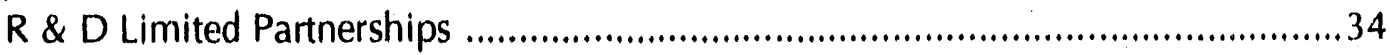

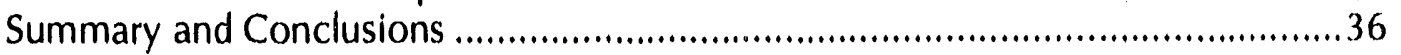

\section{Chapter 3: Business Planning}

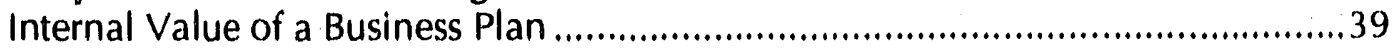

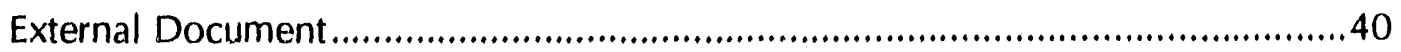

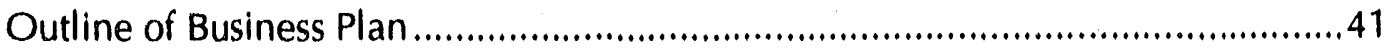

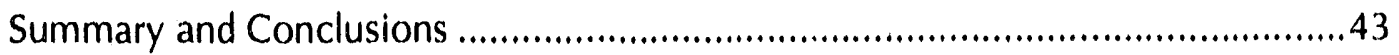

\section{SECTION 2: GETTING STARTED}

\section{Chapter 4: The Dawnbreaker Business Planning Process}

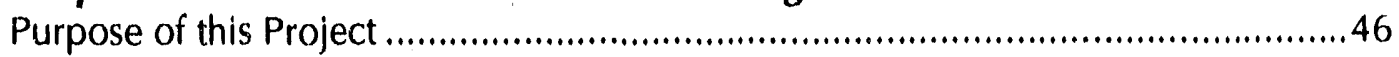

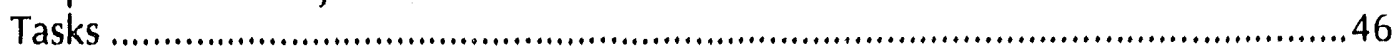

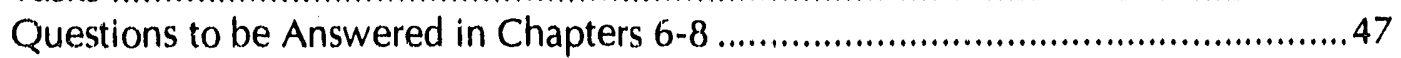

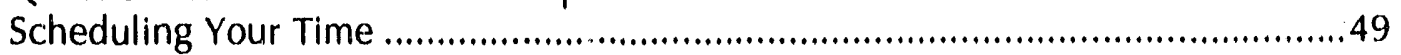

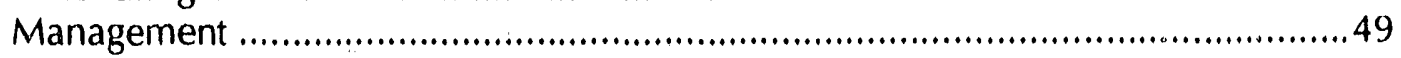

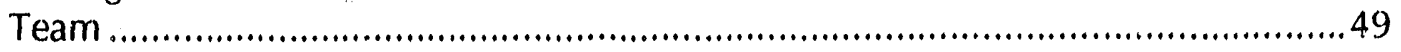

Additional Resources to Assist in Data Gathering ...........................................50

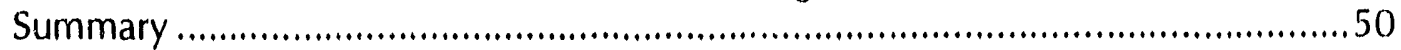

Chapter 5: Benchmark Your Starting Point

Summary: Benchmarking Your MindMap ........................................................ 55

Interim Report \#1: "Mind Map" .............................................................. 57

\section{SECTION 3: WORKBOOK}

\section{Chapter 6: Interim Report \#2}

What is Your Technology/Product?

What are Possible Applications of Your Technology? .......................................... 62

What Decision Making Process Do You Use to Determine Which Applications to

Pursue?

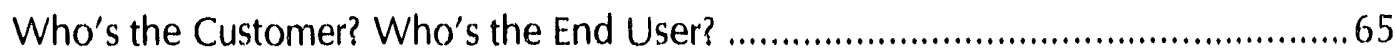

Who will Benefit from These Applications? 
What is Your Sustainable Competitive Advantage? .........................................6. 68

What is Your Company's Organizational Structure? .........................................69

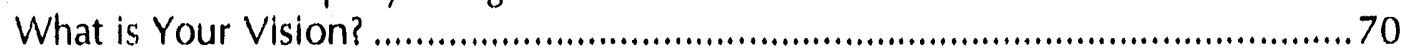

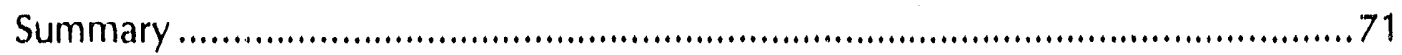

\section{Chapter 7: Interim Report \#3}

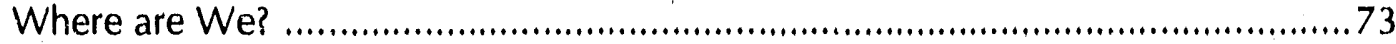

Who Will Be Affected by These Applications? .................................................76

What is the SIC (Standard Industrial Code) Associated with This Technology or

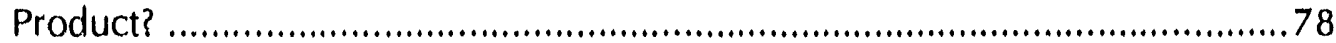

What Need Does the Technology/Product Fill? Is This Need Real or Imagined? ... 80

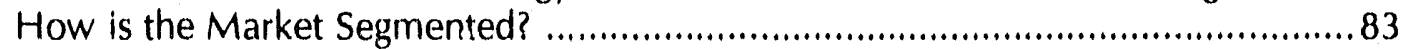

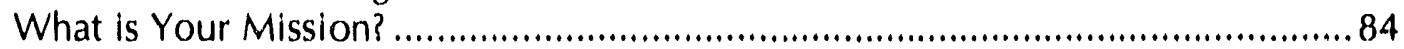

What is the Growth Rate of This Market? ........................................................ 85

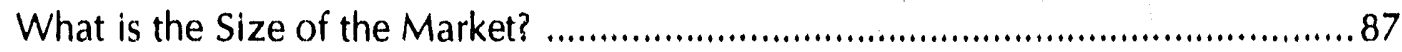

What are the Trade Journals for This Market? ................................................. 90

Who are the Competitors in This Market? ....................................................... 91

What are the Characteristics of These Competitors at Present? ........................... 93

Who Else is Expected to Enter This Market? ......................................................... 95

What Regulatory Agencies Have an Impact on This Industry? ............................. 96

What is Your Company's Sales History for Your Techriology/

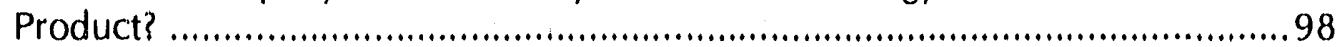

What is the Development Timeline for Your Technology(ies) with Critical

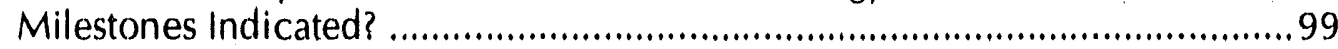

What Kind of Manufacturing Does the Company Perform? ............................. 102

What are Your Company's Financial Requirements .................................... 103

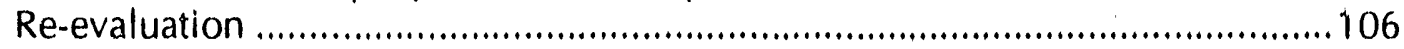

\section{Chapter 8: Interim Report \#4}

Where are We?

How Do you Make Decisions Regarding the Applications or Products

to Pursue?

What are the Features/Advantages/Benefits of Your Technology/Product as

Compared to That of Your Competitors?

What are the Proprietary Features of the Technology/Product? ..........................115

Who Makes the Decisions to Buy? ............................................................... 116

What Distribution Channels do Your Competitors Use? .................................... 118

How Do These Competitors Compare on the Following Items: R \& D

Capability, Marketing Capability, Management, Financial Resources,

and Market Share?

What Would Be the "Barriers to Entry" for a Competitor in This

Market?

What are the Future Projections for Such Products/Technologies between Now

and the Turn of the Century?

What are Your Financial Requirements? ................................................. 124

How Will the Following Affect the Industry: Interest Rate, Tax Benefits,

Demographics, and General Economic Trends? .......................................125

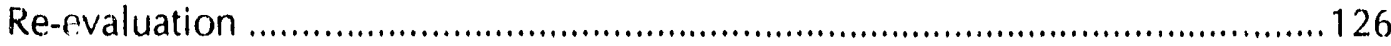

\section{Chapter 9: Putting It All Together}

Where are We?

Preparing for Strategy Development 


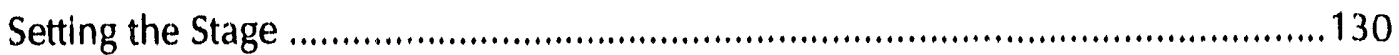

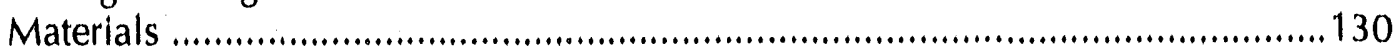

Step 1: Internal Dlagnosis ........................................................................ 133

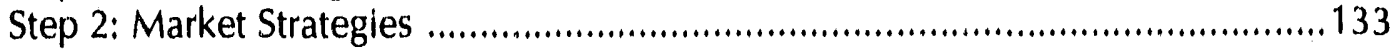

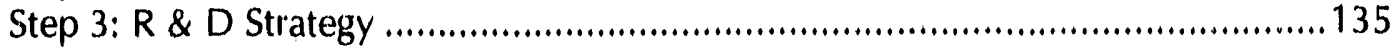

Step 4: Market Strategies ..........................................................................136

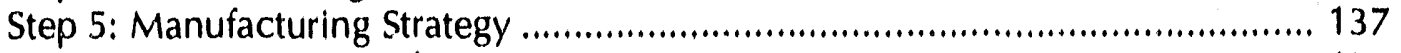

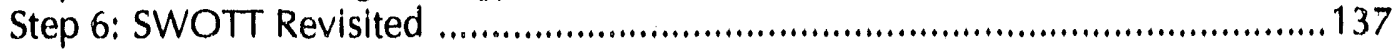

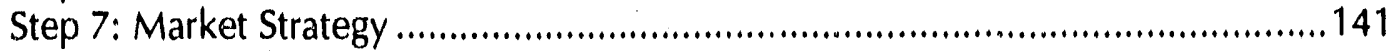

Step 8: Human Resource Plan .............................................................. 142

Step 9: Financial Strategies ......................................................................... 142

Step 10: Re-examine Your Company's Mission and Vision .................................143

Step 11: Writing the Business Plan ................................................................. 143

Chapter 10: How to Use the Business Plan

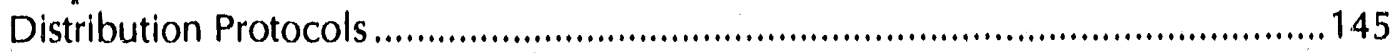

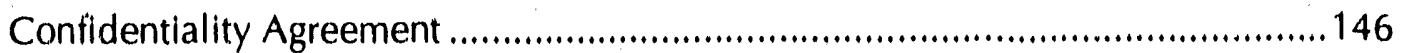

Internal Value of the Plan ...................................................................148

Bibliography 149

Appendix A: Venture Capital Firms that Provide Seed Money 151

Index

\section{TABLES}

TABLE 1: Stakeholder Mapping ……..................................................................

TABLE 2: Industry Preferences of Selected Seed Venture Capital Funds ................21

TABLE 3: Description of SEC Reporting Documents ..........................................3i

TABLE 4: Motivation for Joint Venturing ........................................................... 32

TABLE 5: Criteria to Consider When Looking for a Joint Venture Partner ............... 33

TABLE 6: Financing Arrangements as a Function of Development .........................37

TABLE 7: Cognitive Skills Required in Preparation of Each Interim Report .............51

TABLE 8: Project Planning Guide for Interim Report \#2 ........................................59

TABLE 9: Cognitive Skills Required in Preparation of Each Interim Report .............60

TABLE 10: Features and Advantages of Technology/Product ...................................61

TABLE 11: Generating Alternative Applications for Technology ............................6.63

TABLE 12: Customer Requirements and Product Specifications ..............................66

TABLE 13: Project Planning Guide for Interim Report \#3 ….............................74

TABLE 14: Cognitive Skills Required in Preparation of Each Interim Report ...........75

TABLE 15: Stakeholder Mapping ……………....................................................77

TABLE 16: SIC Codes for Markets, Industries, Technologies, and Products ............79

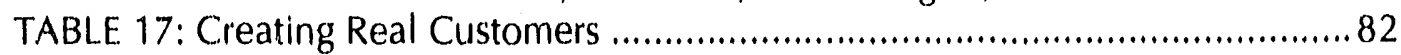

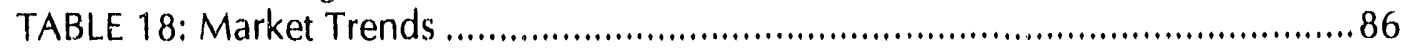

TABLE 19: Market Size of Total and Served Available Markets ..............................89

TABLE 20: Detecting Competitors ...................................................................99

TABLE 21: Creating Good Competitor Files ....................................................99

TABLE 22: Regulatory Agencies....................................................................97

TABLE 23: New Product Development and Release Activities ..............................100 
TABLE 24: Creating an Expense Budget ....................................................... 104

TABLE 25: Re-evaluation Worksheet .......................................................... 107

TABLE 26: Project Planning for Interim Report \#4 .......................................... 110

TABLE 27: Cognitive Skills Required in Preparation of Each Interim Report ........ 111

TABLE 28: Feature, Advantage, Benefit (FAB) Analysis ..................................... 114

TABLE 29: Buyer Behavior .............................................................................117

TABLE 30: Distribution Channels for Your Competitors and Customers ............... 119

TABLE 31: Competing Technology Analysis ................................................ 123

TABLE 32: Re-evaluation Worksheet ........................................................ 127

TABLE 33: Key Customer Sales Analysis (Historical) ........................................ 131

TABLE 34: Commercial Technology/Product Sales Analysis (Historical) ............. 132

TABLE 35: Competitive Analysis ............................................................. 138

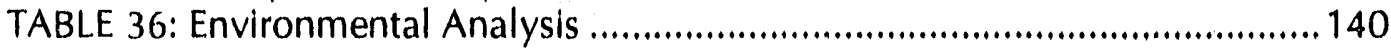

FIGURES

FIGURE 1: Commercialization Process .......................................................... 1

FIGURE 2: Selecting the Most Viable Applications and Products ........................... 3

FIGURE 3: Required Commercialization Resources as a Function of

Devrlopment Phase ........................................................................4

FIGURE 4: Commercialization Spoof ........................................................ 4

FIGURE 5: Stages of Venture Capital Financing .............................................19

FIGURE 6: Preferred Types of Alliances ...........................................................26

FIGURE 7: Alliances Involving US or International Partners............................... 27

FIGURE 8: US Patents issued (1990) by Country ..............................................28

FICUURE 9: Flow-Chart of Items to Clarify When Beginning a New Project ........... 45

FIGURE 10: Different Types of Innovation ....................................................5 53 


\section{CHAPTER 1: COMMERCIALIZATION PROCESS}

This first Chapter is devoted to clarifying definitions and perspectives. So often, the opportunity for effective communication is lost at the outset because fundamental concepts go undefined. Not wishing to commit this same error, attention will be given to terms and concepts that will be referenced throughout this book.

\section{TERMINOLOGY}

The term Commercialization refers to realizing a profit and/or savings from the widespread use of the technology to the private sector. Three distinct stages are commonly involved: Technology Development, Product Development, Exploitation.

Figure 1: Commercialization process

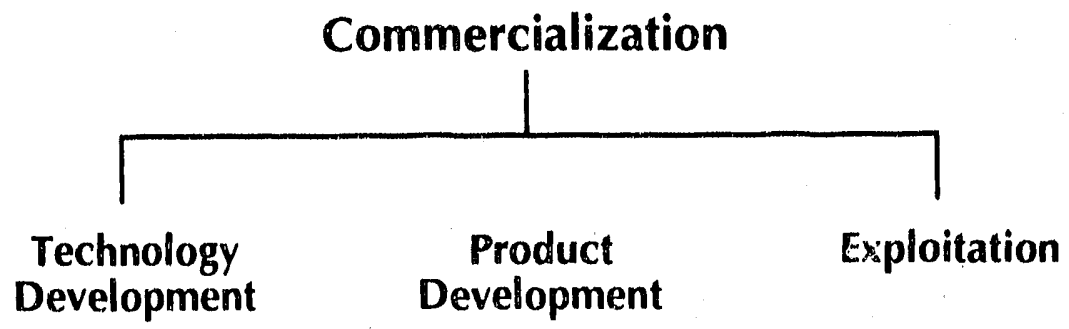

Technology Development: Technology development is initiated in many settings: universities, government R \& D labs, small businesses and large corporations. Technologies tend to be basic in nature and involve finding solutions to fundamental problems. Before moving on to the next stage (Product Development), a divergent thought process must occur which requires that various applications be considered and those which have the greatest commercial viability are selected.

Product/Process Development: Product development refers to the utilization of the technology in products/processes that have a recognizable value to end-users.

Exploitation: Exploitation refers to making money with the product/process either from increased savings and/or profitability resulting from the sale of the product/process by the private sector. Widespread adaptation and adoption also serve as indices of effective exploitation.

\section{PERSPECTIVES IN THE COMMERCIALIZATION PROCESS}

The first stage of the commercialization process, Technology Development, is usually accomplished by a small, fairly homogeneous group of scientists, engineers, and technicians. With the exception of large corporations, funding for technology development tends to come from government agencies and foundations. Grant writing is the accepted mechanism for procuring funds. Proposal acceptance tends to be based upon:

- the scientific and technical merit of what is proposed;

- the credentials of the parties executing the work;

- the availability of facilities and equipment needed to conduct the research.

As effective proposal writing is often a pre-requisite for obtaining tenure, the scientist must become very skilled in this area. 
As one moves to the stage of Product Development, the vantage point required for success must shift. What is now required is an emerging sensitivity to the commercial marketplace as well as to various sources for obtaining private funding. As scientists tend to be highly specialized, it is at this point that the staff needs to begin diversification. Although scientists can be sensitive to the marketplace, more often than not this is not the case. Hiring an extra pair of "eyes" with a different perspective is not only useful, but essential at this point.

During product development the staff must rigorously examine various alternatives and dismiss those which do not have a high likelihood of yielding additional monies on a timely basis needed for product development. This examination requires that the scientists reach beyond the intended use of the technolcgy and entertain other applications, many of which may be quite distant from the initial use of the technology. It is often difficult for scientists who have conceptualized the technology in one fashion to break with their original paradigm and view the technology from a different vantage point. Although many applications are possible, in order for the business enterprise to survive the selection process must focus on those applications for which there is the greatest market need, as well as the greatest likelihood of finding investment dollars. Grant monies continue to be a viable source for product development, however, the scientist must begin to develop a total business perspective, rather than one based solely on the technology. This perspective will lead the management team to focus on the commercial viability of the product, rather than only the technical merits of the technology. As the delight for the scientist comes from the technology, this transition is often difficult. 
FIGURE 2: Selecting the most viable applications and products

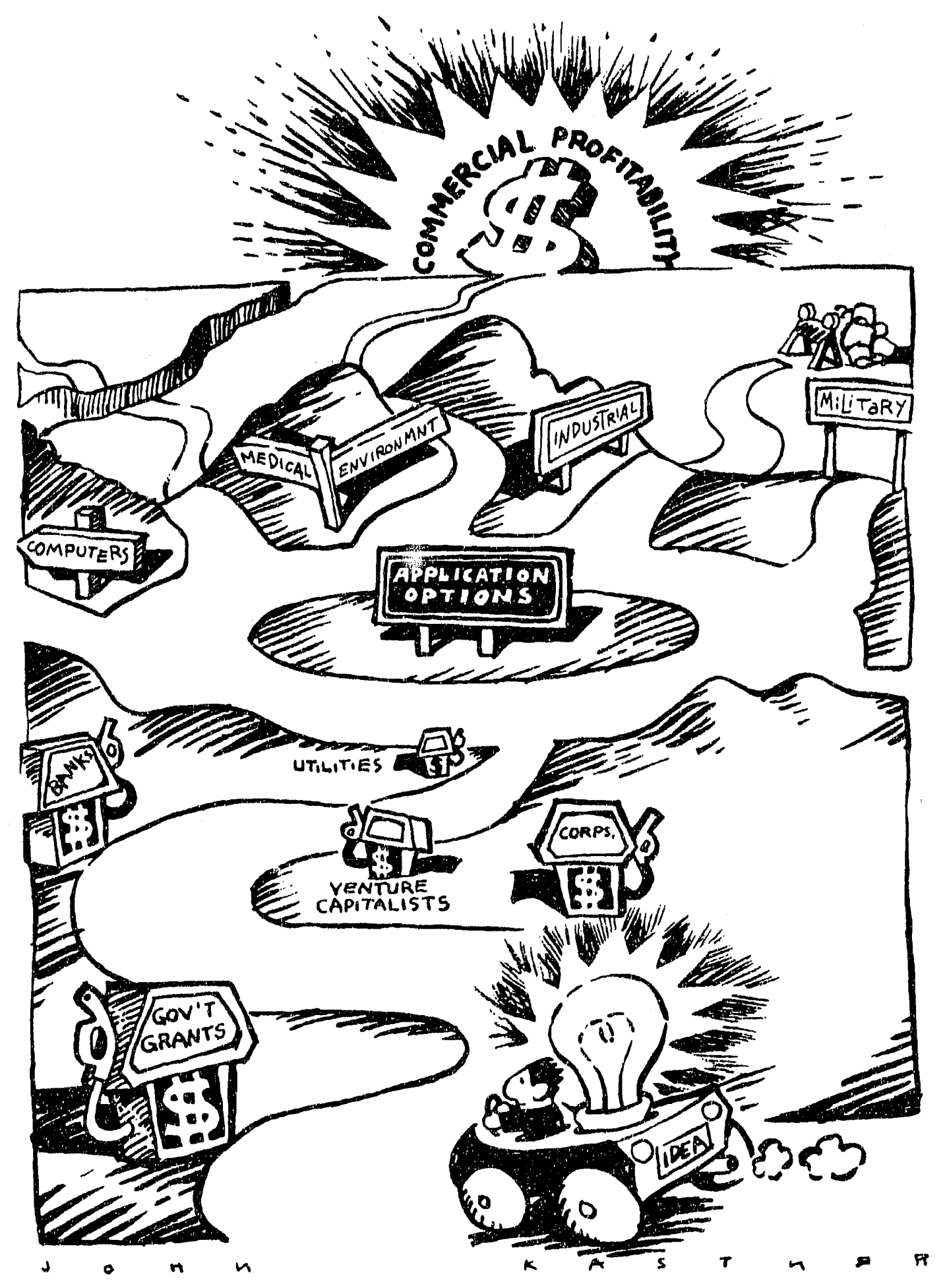


FIGURE 3: Required commercialization resources as a function of development phase

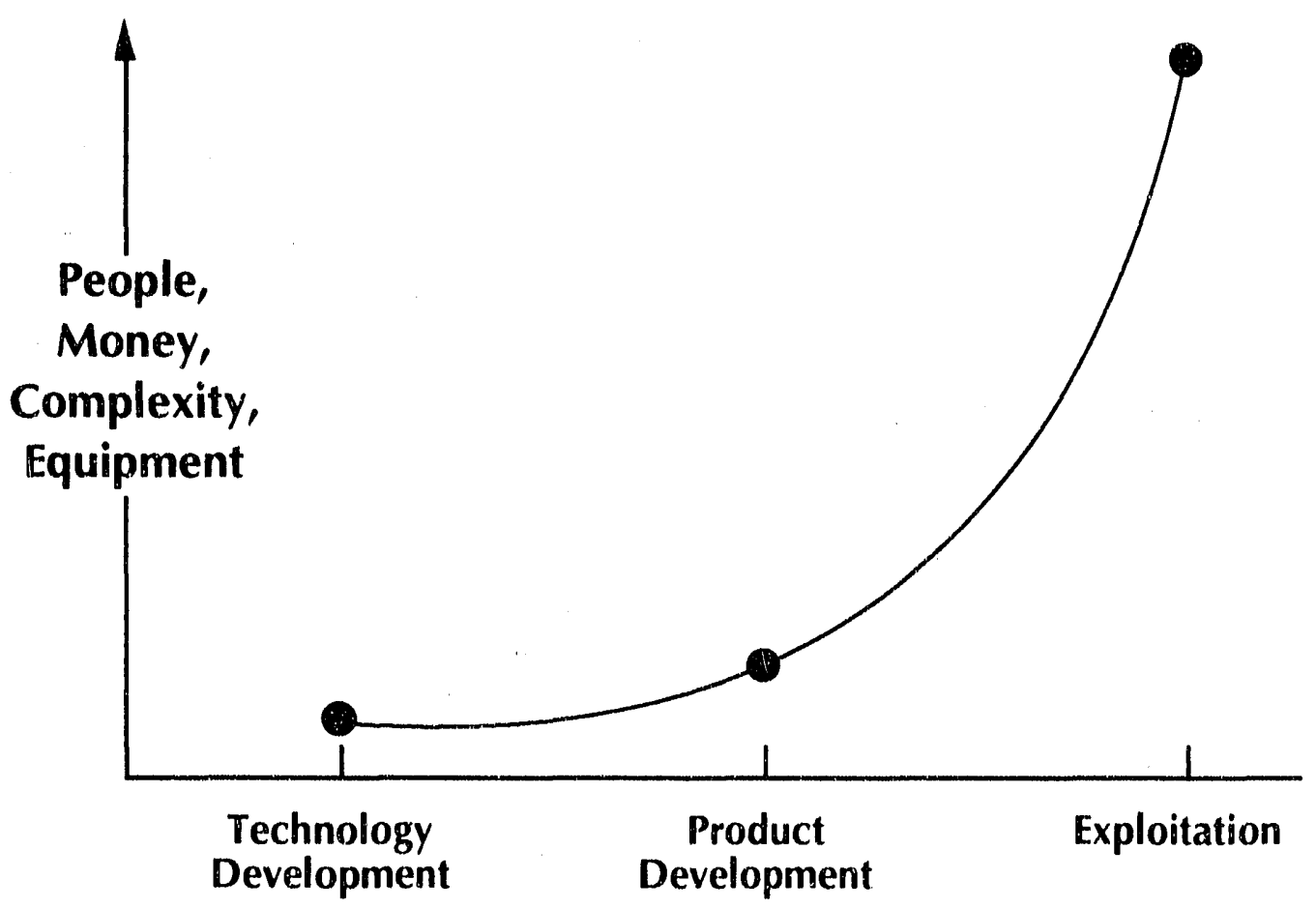

The shift from Product Development to Exploitation is the most difficult phase of the commercialization process. The number of people, resources, and dollars required, as well as the overall complexity, increases exponentially.

FIGURE 4: Commercialization spoof
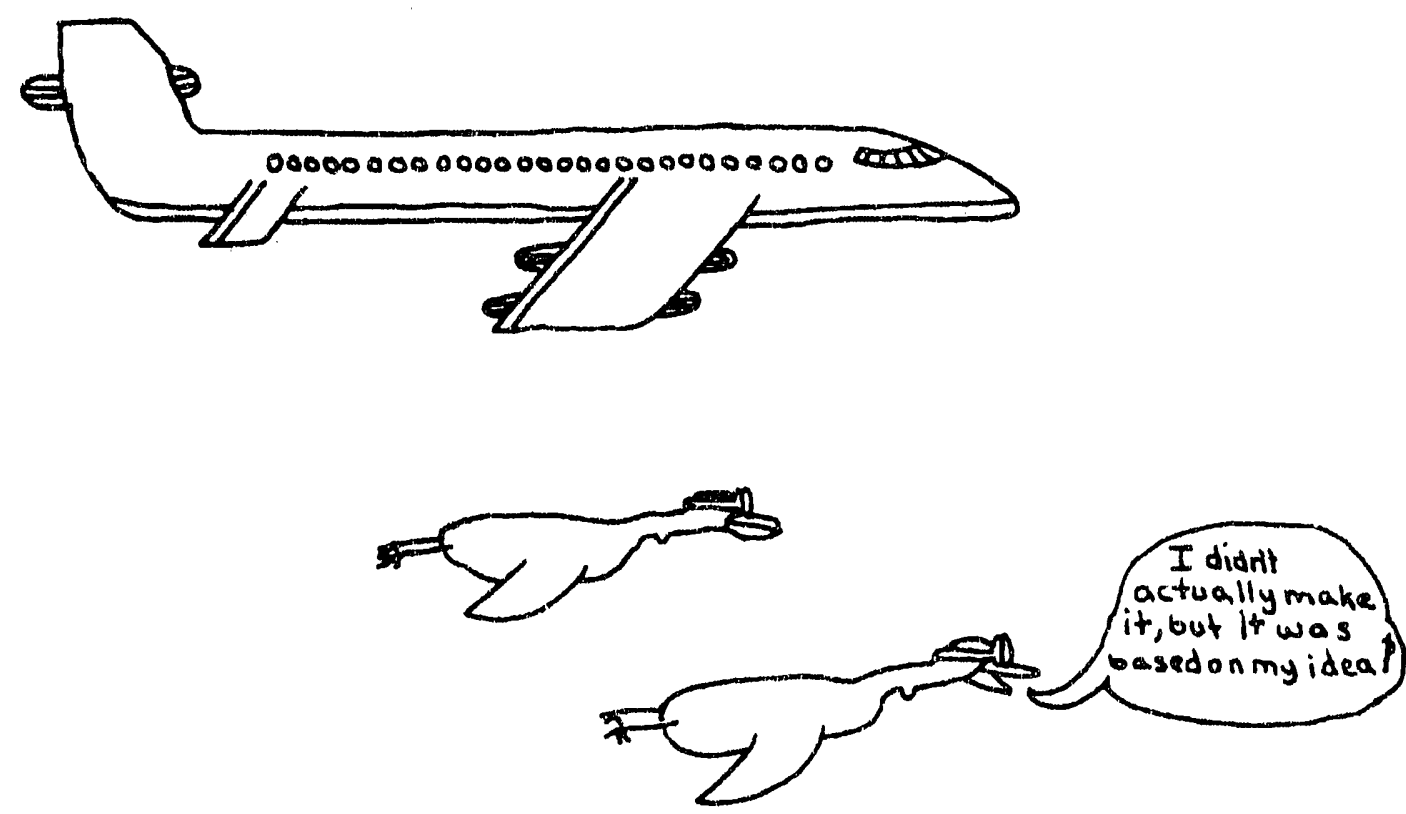

John K. Servo 
Although the scientist contributes greatly during the technology development phase, the amount of time, effort, and resources required to transform the technology into a viable commercial product/process is many times greater than that which the scientist has already invested. Successfully moving along the commercialization continuum requires, above all, great skill at coalition building.

This coalition is built among a large informal cast of p'ayers referred to as Inventors/ Scientists, Gatekeepers, Champions, Sponsors, and Stakeholders. This is the commercialization team. It evolves informally over time and includes both people inside and external to your organization. They are recognized by the role they play and not by the existence of any formal relationship with your company.

The responsibility for knitting together the commercialization team rests with the company's management team. The latter refers to those employees in your organization who play a management role and who represent the key functional areas (technology, marketing, finance, and administration). In many entrepreneurial companies, it is not uncommon at the outset to have one person play all of these roles. However, as the organization continues to grow, different people usually become assigned to each of these functions.

\section{PLAYERS IN THE COMMERCIALIZATION PROCESS}

Borrowing from the literature on product innovation, a great deal is known about the cast of players required to move an idea from conception to successful commercialization.

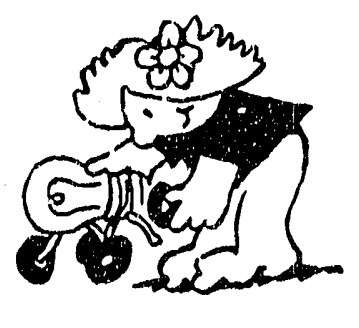

\section{Inventor/scientist}

Inventors/Scientists like to reduce the idta to practice; in fact, they savor it. For inventors and scientists alike the challenge is in solving the problem, in putting the solution into a 'angible form. More likely than not, their inventions are not initially in a marketable form.

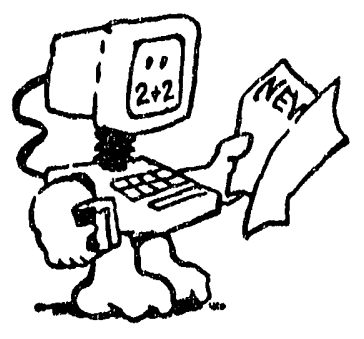

\section{Gatekeeper}

Another important role is that of a Gatekeeper. The term "technology gatekeeper" was initially applied, however, the intent is more broad. A gatekeeper is anyone who has cutting-edge information. Such a person could be a scientist, lawyer, accountant, market research firm - in short, anyone who can provide you with needed information quickly. The information the gatekeeper provides serves as the context in which the technology needs to grow. 


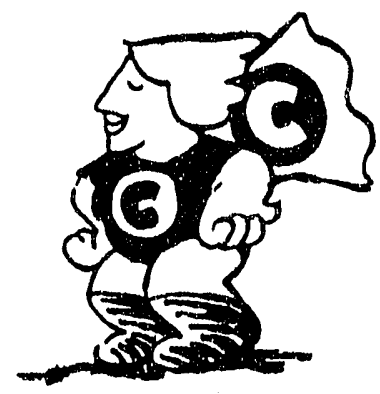

Champion

A Champion is a person with status or clout who advocates on behalf of another. Champions, in fact, provide legitimacy to an inventor. They serve as a bridge, a translator between the more unconventional inventor and the more traditional parts of an organization or society. Without champions, few products go forward. They are the unsung heroes of any great invention. Many champions are necessary in the evolution of a product. However, the 'initial champion' must be the scientist himself or herself. In other words, in order to go forward the scientist must also assume this role and forge a coalition, involving this cast of players. For the sake of this discussion, you should assume that all champions (other than the 'initial champion') are individuals outside your organization who can be influential in bringing you and your technology/product to the attention of others. This is usually done informally.

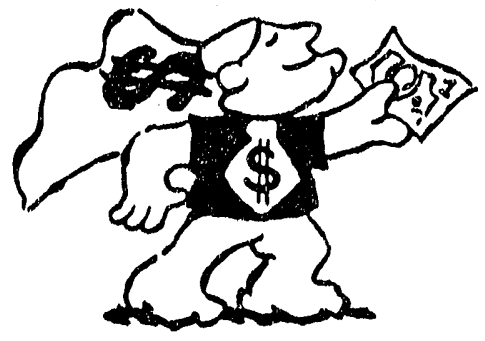

Sponsor

A Sponsor has resources (money, equipment, human resources) and applies them towards the development of an idea. A sponsor usually has higher status within an organization and a proven track record. Some organizations have evolved specifically to play the sponsorship role. Banks, small business associations, angels, venture capitalists, and the like all act as sponsors. They all share the weight of financial responsibility and are very cautious about investing the funds with which they are charged. Return on Investment (ROI) is clearly the motivating force. The phrase "I'm from Missouri, prove it to me" definitely applies to sponsors. They cannot afford to be blinded by the "Gee whiz" aspect of an invention. Much to the disappointment of the inventor, the technology is usually taken as a given. What they want to know is who will buy the product, what is the competition like, and who are you, anyway? "Conjecture must be turned to certitude." They must be convinced there are people who will buy the product in a timely fashion, and that you can manage the enterprise. 


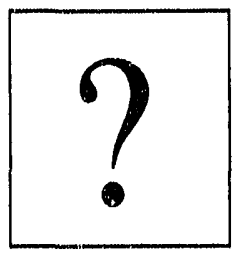

\section{Stakeholder}

A. Stakeholder is anyone who will be affected by the innovation. He is often the forgotten player. Stakeholders should be approached during the process of collecting market research. The users of the old technology or product are stakeholders. How readily will they embrace a new technology which may make obsolete a technology in which they have invested heavily? What can you do to minimize their resistance and involve them with the new?

\section{Table 1: Stakeholder Mapping}

1. Identify the Stakeholders.

2. How do you think they will be effected by this product/process?

3. How will they perceive the impact of this product/process?

4. List what you know about the stakeholders.

5. If you don't know anything about them, find out what you can.

6. What is the stakeholder's view on this product/process likely to be? Why do you say that?

7. What will the stakeholders gain from this new product/process?

8. If the stakeholders have considerable power, identify people that the stakeholders respect ("influencers").

9. How can you minimize risk and maximize reward for the stakeholders?

10. If stakeholders do not have a lot of power, involve them in the development of the idea early on, especially if they are gatekeepers.

11. Listen to stakeholders input and modify the product/process so that it is more adaptable to the environment.

12. If stakeholders have a lot of power, include their influencers in the product/process at an early stage. Try to have the influencers become your champions.

Although this cast of players is described as unique, one individual may play multiple roles. For example, a person may simultaneously be an inventor, champion, and sponsor. However, oftentimes these roles are discrete. Another important item to remember is that multiple players are required in each category. In other words, you will need many gatekeepers, champions, and sponsors to realize the successful commercialization of a product or technology. The successful entrepreneur is one who can locate these other 
players and involve them as part of the commercialization team. Coalition building is key!

\section{DEVELOPING AND FINDING THE COMMERCIALIZATION TEAM}

Coalition building involves bringing in champions, sponsors, and stakeholders and making them a part of your vector of support.

\section{Looking for Champions}

Generally, you should look for champions before you look for potential sponsors. Again, keep in mind that potential sponsors are potential investors. They reside within corporations, utilities, government, universities, banks, and venture capital firms in geographically diverse locations. As you may only have one opportunity to present your business opportunity to a potential sponsor, it would be to your advantage to know as much as possible about that organization and the players beforehand. You can leverage your effectiveness in this process by developing champions internal to those organizations. A champion who knows your work, knows you, and thinks well of what you can do can help maintain your presence in the other organization. Champions leverage your opportunity for success by helping you become more sensitive to the potential sponsor's needs. Such considerations must be made early so that your technology will evolve in a way that is desirable to potential sponsors.

\section{Where to look for champions for your technology.}

\section{R \& D, manufacturing}

Some people look for champions at the top of an organization. We recommend that you delay doing this until you "have your act together." One of the best ways to find contacts within R \& D or Manufacturing is to look through Association Membership Directories or by scanning Conference and Convention Proceedings. The Encyclopedia of Associations. found in the reference section of most libraries, is a very useful resource for finding the names of associations that deal with your area of interest. Another resource that can be consulted is the Directory of Conventions which lists upcoming conventions. Generally speaking, the first potential champions to be approached should be within the technology area. The scientist/inventor is best equipped to make the initial contact.

Another way to begin developing champions is through people exchange programs.

Many universities and federal labs are beginning to encourage this by offering their services as consultants and/or inviting employees from the company in which they are interested to work within their organization for a period of time.

\section{Where to look for champions for your products.}

\section{New product development, engineering, and marketing divisions}

In addition to the sources mentioned above, another useful source to regularly review is the local paper. New product introductions and/or technological advancements are commonly announced in local media. Subscribe to the paper in those cities in which companies of interest are headquartered. You can obtain many names in this manner. Another useful source is Dialog, which is an information provider. Dialog has an SDI service (Selected Dissemination of Information) which can be used to automatically send you updates of information on topics of interest. (There is a fee for service.) Dialog can electronically scour local newspapers and technical newsletters worldwide to provide you with information of interest. For a small company, the easiest way to obtain access to this service is through your university library. For larger companies, it is best to train some- 
one within marketing in be facile with various electronic databases. He can initiate SDI services from his terminal.

When you approach potential champions, initial discussions should be general. You will be most successful if you do not approach them with the intent of selling, but with the intent of defining a potential customer's need. In order to be successful, you need to be viewed as a potential ally as quickl; ; as possible, rather than as an outsider.

Another point to keep in mind is that when you do seek a sponsor, you will be competing for dollars that managers could spend internally on development projects. Your project has to represent a clear opportunity rather than a distraction; moreover, becoming involved with your project must be a benefit to everyone involved, as well as to the corporation. If you have SBIR Phase II funding, the fact that you bring development dollars with you is of great advantage. Likewise, if you have accomplished considerable development on a needed technology, that too is advantageous.

\section{Looking for Sponsors}

Potential sponsors are brought into the picture at a later time, when your business opportunity is clarified. Champions can be helpful in telling you who the potential sponsors are within their organization. They will not refer to them as sponsors, so you will need to inquire who is responsible for making decisions about strategic partnerships, joint ventures, and licensing.

Other portals that you can approach directly are:

\section{Legal Departments}

Many people who are responsible for licensing or corporate acquisitions work within the legal department of an organization. Although, some companies have separate departments for licensing, many will be a subset of the legal department.

Call the general information number for the company of interest and ask them to direct you to this department. Ask them who is responsible for "Licensing, Corporate Acquisitions, and the like." Some receptionists won't know what these terms mean, and you may need to describe the concept. Four or five phone calls will usually get you to the right plact. Another source that can be consulted for the names of people responsible for licensing is the Membership Directory for the Licensing Executive Society. This directory lists members by company name.

\section{New Business Development Areas}

Some of the larger companies have departments devoted specifically to new business development and /or venture development. In the past large corporations tended to acquire smaller, high tech firms in an effort to obtain the desired technology. However, the clash between the culture of the small entrepreneurial company and the larger Fortune 500 companies frequently proved damaging. The glacial speed with which decisions are made in large corporations and the cumbersome accounting procedures often knock the wind out of zestful, fleet, entrepreneurial teams. To address this issue, some large companies have established their own venture capital funds, to help encourage promising technology along.

\section{Submitted Ideas Offices}

Many large organizations have departments established specifically to deal with ideas submitted from outside the company. Kodak, for example, has a Submitted Ideas office to handle such inquiries. In such organizations, this is the portal the company wishes you 
to approach. However, you will have the greatest luck in finding a champion if you attempt to gain access to the organization at multiple levels.

\section{Vice Presidents of various divisions}

In the business section of most libraries one can find numerous directories which list the names of Vice Presidents of the major functional units of an organization. The most commonly used are Dun and Bradstreet's Million Dollar Directory Standard and Poor's Register of Corporations. Directors and Executives, and Moody's Manual Although some people begin by making contact at the top, we have found it better to make initial inquiries lower in the organization. In this way, by the time you get to the top you know more about the organization and its needs and can make a better impression with decision makers.

As you can surmise, within large organizations decisions regarding funding involve numerous people and are made with great caution. Any potential sponsor will have to convince others that your opportunity is a better one in which to invest than others and that minimal risk is involved. In order to do this successfully, you must provide the potential sponsor with the information that is needed to convince others. The typical vehicle for doing so is a business plan, which includes your compilation of the information that best represents the opportunity your technology represents to the potential investor. When secking a sponsor within an established company, the NIH (Not Invented Here) factor is quite high. The best way to combat this tendency is to introduce the new technology to the organization early in its development and involve others with its growth and development. NIH is usually more pronounced when the technology is introduced into another organization later in its development.

In summary, you will be most successful in obtaining sponsorship funds if you bear in mind that potential sponsors:

- must be able to justify the expense to others,

- look to minimize risk,

- look to maximize return.

- live in highly dynamic environments

\section{SUMMARY AND CONCLUSIONS}

Commercialization is a lengthy process involving many players. It unfolds in a fortuitous, somewhat unpredictable fashion. To recap the themes of this chapter, let us demonstrate the importance of a commercialization team by describing the rarely told story of Alexander Graham Bell in an abbreviated fashion.

Alexander Graham Bell arrived in Boston in 1870. The Scottish immigrant supported himself by various means: as a Professor at Boston College, a tutor of the hearing impaired, guest lecturer, and promoter and organizer of Conferences for the Deaf and Dumb. Bell immersed himself in audiometry, telegraphy, and communication, working on many related inventions, including liquid and harmonic transmitters.

Gardiner Hubbard and Thomas Sanders, both fathers of deaf children tutored by Bell, became his champions and later his sponsors offering to fund his research in exchange for a percentage of the patents to be filed (1/3 each).

Hubbard's interest in investing in Bell's work was prompted by the possibility of outdoing his prominent adversary, William Orton, President of the Western Union Telegraph Company. Hubbard had lobbied actively in Congress for passage of a bill authorizing the formation of a United States Telegraph Company. This bill, also referred to as "the 
Hubbard bill," would have benefited Hubbard greatly if passed, making him a major figure in the nation's telegraph industry competing with William Orton.

Orton prided himself on his company's technological prowess. A new invention of Thomas Edison, then a young man in his mid-20's also working on the lield of telegraphy, had been purchased by Western Union. Hubbard also received information indicalling that Elisha Gray was conducting experiments in telegraphing sound. The race was on! After thoroughly searching the patents and caveats, Hubbard decided to invest in Bell. Bell provided the ideas and product development activities, and Hubbard and Sanders provided the cash.

Complications with the patent law and Bell's lack of skill in electriclty were slowing down his progress. At Hubbard's bidding, Bell sought expert help (technology gatekeepers) from Hubbard's Washington attorney and from a celebrated electrician. With their assistance, work on telephony continued feverishly in an effort to beat Gray and Edison. In October 1875 Bell began to draft the specifications for the patent. However, poor health resulting from over exertion, lack of money, and his love affair with Hubbard's daughter (who later became his wife) slowed him down. On February 14, 1876 "Hubbard went ahead without consulting Bell and formally filed the undulatorycurrent and telephone application at the Patent Office on the morning of February 14. Later that same day, Elisha Gray's attorney entered Gray's caveat for a speaking telephone on the liquid variable resistance principle (Bruce, R., 1973, p. 168)." Although a patent interference was called involving Elisha Gray, Paul LaCour, and Alcxander Graham Bell, the patent was awarded to Bell. Due to Hubbard's diligence, as well as the risk of taking things into his own hands, the proper paper work was in the hands of the right people at barely the right time.

Bell showed little interest in the commercialization of the telephone. He was content to be known as the inventor and wished to be free to work on the many things which interested him. Gardiner Hubbard became the major champion for the telephone. In 1877 he spent half a year traveling the country looking for a major investor. However, none came forward. Hubbard and Bell approached Western Union Telegraph, but as Orton (a stakeholder) had once indicated, "The Western Union will never take up a scheme which will benefit Mr. Hubbard." The text of the rejection letter follows on the next page. 
Chauncey M. Depew, Esq.

November 15,1876

Western Union Telegraph Co.

New York City

Dear Mr. Depew,

This committee was formed at your request to consider the purchase of US Patent 174,465 by the Western Union Company. Mr. Gardiner G. Hubbard and Mr. A.G. Bell, the inveritor, have demonstrated their device which they call the "telephone" for us, and discussed their plans for its use.

The "telephone" purports to transmit the speaking voice over telegraph wires. We found that the voice is very weak and indistinct and grows even weaker when long wires are used between the sender and receiver. Technically, we do not see that this device will ever be capable of sending recognizable speech over a distance of several miles.

Messrs. Hubbard and Bell want to install one of their "Te'ephone" devices in virtually every home and business establishment in the city. This idea is idiotic on the face of it. Furthermore, why would any person want to use this ungainly and impractical device when he can send a messenger to the local telegraph office and have a clear message sent to any large city in the United States?

The electricians of our own company have developed all the significant improvements in the telegraph art to date, and we see no reason why a group of outsiders, with extravagant and impractical ideas, should be entertained, when they have not the slightest idea of the true practical problems involved. Mr. G.G. Hubbard's fanciful predictions, while they sound very rosy, are based upon wild-eyed imagination and a lack of understanding of the technical and economic facts of the situation, and a posture of ignoring the obvious technical limitations of his device which is hardly more than a toy, or a laboratory curiosity. Mr. A.G. Bell, the inventor, is a teacher of the hard-of-hearing, and this "Telephone" may be of some value for his work, but it has too many shortcomings to be seriously considered as a means of communication.

In view of these facts, we feel that Mr. G.G. Hubbard's request for $\$ 100,000$ for the sale of his patent is utterly unreasonable. Since the device is of no inherent value to us, we do not recommend the purchase.

Yours truly,

(Name deleted)

for the Committee 
Unable to excite interest in large investors, George Hubbard and Thomas Sanders formed the Bell company, an unincorporated, voluntary association. Rights to Bell's invention were reassigned to Hubbard. Hubbard was the trustee and principal officer of the new Bell Company; Sanders, who had the largest investment, became the Treasurer; Watson became the first Superintendent of telephone instrument production; ant Bell, the company electriclan.

The business community viewed the telephone with great skepticism, alleging that it would receive poor acceptance in the business community where written records were required. In 1877 Bell began to give demonstrations. Hubbard, who was noted at recelving publicity, had the story carried by many newspapers. Market interest was generated in the home consumers via the public press.

"Cash-poor," Hubbard developed a strategy to develop the company with "OPM" (Other People's Money) via a leasing and licensing procedure. "Hubbard began enlisting a small army of local agents across the country. These agents were contracted to lease the company's equipment to customers in return for an annual commission, usually $40 \%$ on each telephone during the agent's first year of operation and 20\% thereafter (Garnet, $R$. 1985 , p. 14) (\$20/year for dwellings and $\$ 40 /$ year for businesses, payable in advance.) This strategy enabled Hubbard to finance the company's growth.

Most of the initial agents were either electricians or notable citizens who were also friends of the founders. The agents were in a favorable position to positively influence public opinion. This strategy of licensing and leasing, with hefty incentives for the distributors (agents) allowed Hubbard to shift the costs of marketing, construction, and operations to the agents.

The first telephones allowed communication only between one locatior and another, as switchboards were only embryonic at the time. Lengthy lines would nej to be strung between locations desiring to communicate. The fact that lines needed to be strung also allowed another source of income for the agents, who received a hefty profit. Many patent infringement cases arose and were addressed aggressively by Hut,bard, who had been very careful in the development of Bell's patent position.

Hubbard was an excellent promoter (champion, turned sponsor, turned en trepreneur). By the end of 1877 many people wished to license and lease telephones. How'ever, Hubbard was a poor administrator. Sanders, who was more heavily invested, saw that financial collapse was quickly Imminent. In December 1878, Sanders recommended refinancing the venture with input from others. Hubbard resisted, not wishing to dilute control. However, Western Telegraph was looming on the horizon and was making many advances in telephony. The nascent company needed more financial resources to withstand the threat of Western Union. Hubbard conceded. In 1878 the New England T'elephone Company was formed with the backing of a new financial constituency (sponsors) brought into the picture by Sanders.

Later that year Western 'Telegraph did enter the market with the patents of Elisiza Gray and Thomas Edison. More capital was required. So again, in the final months of" 1878 , another round of funding was brought in, and Hubbard was removed from his decision making role.

Without the active involvement of numerous gatckeepers, stakeholders, champlons, and sponsors this story would have had a different ending! 


\section{CHAPTER 2: POTENTIAL FUNDING SOURCES}

The type(s) of funding you should seek depends in large part upon the development timeline associated with your technology. Not all funding options are available at all points in the development life of a new technology or product. The types of options most commonly sought in order to continue with commerclalization include:

(1) Getting Close to the Customer

(2) Equity Investment Capital from Venture Capitalists and Business Angels

(3) Initial Public Offering

(4) Strategic Alliances

(5) Licensing the Process or Product

(6) Forming a Joint Venture

(7) R \& D Limited Partnerships

The purpose of this chapter is to describe each of these options to some degree so that you may give due consideration to each option. The process we have followed in describing each of these options is to:

- provide a definition,

- Indicate when this type of funding is most appropriate,

- Identify the process involved with obtaining the funding,

- Identify the trade-offs the entrepreneur should consider, and

- provide examples.

In considering these options, be sure to reflect upon your own aspirations; the strengths and weaknesses of your company; the strengths and weaknesses of the organization(s) with which you are considering involvement; and your funding requirements.

\section{GETTING CLOSE TO THE CUSTOMER}

\section{Definition}

During the past 10 years there has been a major revolution in American industry that involves "getting close to the customer." Prior to the 1980's the dominant approach had been to ASSUME what the customer wanted and of course, the customer wanted what you had to offer. But as many people have said, "to ASSUME means to make an ASS of $\mathrm{U}$ and ME." You must talk with the potential customer at every point in the development of your technology or product.

As specialists, scientists tend to be far removed from their potential customers. Like so many others they assume what the customer wants. However, there is no substitute for "asking the potential customer." There are many ways in which this can be done. Depending on the extent to which your intellectual property has been protected, you will need to modify the approach that you take to collecting information. However, the benefit of getting close to the customer cannot be over-emphasized. Developing an early relalionship with a potential customer increases the likelihood that you will have a customer. Early interaction also gives you an opportunity to learn the customer's product or technology specifications. These specifications will have to be met before a customer buys, so why not find out what these are early in the game while you have R \& D funding? 


\section{When should this be considered?}

It is wise to contact potential customers as early as possible, using feedback from potenthal customers as part of the screen used to determine which applications are best to pursue, and what direction development should take.

\section{Who should constder this?}

For the most part, your customers will be manufacturing companies that could utilize your technology or product on both a domestic and international basis.

\section{Process description}

When looking for an industrial customer, use the process described earlier to locate potential champions. Your potential customers could also be your potential champions. Below is a hypothetical first phone contact with a potential customer. The prooess started with:

\section{Carefully selecting the person to approach by determining:}

- Which companies to approach

- Developing a contact list within those organizations, obtained by looking for names in trade Journals, trade associations, conference proceedings, Standard and Poor's register, local newspaper articles, and/or conversations with the receptionist or public relations department of the organization in question, and

\section{Deciding your objectives for the contact, being mindful of}

- What information regarding your company and research you are at liberty to discuss, given the degree of intellectual property protection for your technology

Listed below is a hypothetical initial conversation. The person called is a scientist working in R \& D at a Fortune 500 company. His name was obtained from looking through a Solar Energy Conference Proceedings. The objectives for the phone call were to find a receptive person with whom to begin a discussion, to gain some confldence in cold : calling, and to look for an opportunity to visit Company $X$.

SRIR Company: "Hello, my name is Dr. Smith from XTech. We're an R \& D firm working in the field of solar energy. Do you have a few minutes to talk or have I caught you at a bad time?

\section{Potential Customer; I have a few minutes.}

SBIR Company: I'm not sure if I'm talking to the right person, so let me give you a brief overview of why I'm calling. Perhaps you can assist me or direct me to the correct person.

Potential Customer: Fine, I'll try.

SBIR Company: As I mentioned, XTech is an R \& D firm working on various solar energy applications. I noticed in trade journal " $X$ " that your company has been doing some work in this field. As our goal is to develop a technology that will ultimately serve the needs of end users such as yours, I wanted to explore the features that would make this more useful. For example, we've been working on the development of application $Y$, assuming that this would be advantageous to the customer. From your perspective is this the type of application that is needed?

Potential Customer: Well, you are talking to the right person. We have been doing some work in that area for awhile. Although I'm not at liberty to give you a lot of information. 
and I can only share my perspective, I can address that question. Tell me a bit more about what you're doing.

The conversation would proceed with both of you trying to find a common ground for discussion. Keep in mind that both parties will have constraints on the type of information that can be shared. In this initial contact, you are trying to develop some rapport and the basis for future discussions. We recommend that you contact numerous people within an organization, trying to assess customer needs and finding a point of entry. It would be best to look for people in new product development, marketing, $R \& D$, or customer service to gain as complete a perspective as you can. End the conversation by thanking the Potential Customer and leaving the door open for you to contact him again.

\section{Example}

Entech received its first SBIR grant in 1986. Their decision to respond to RFP's has traditionally been driven by the company's marketing and financial strategies. Routinely, Entech examines the market looking for "market-pull" opportunities for their technologies and products. If they see opportunities to commercialize a particular application, they then examine RFP's from the various federal agencies to determine if there is a good strategic fit. Entech will not bid on RFP's for which they have not independently assessed a market need that fits with their company's mission.

Entech manufactures a widget that is sold to manufacturers of a high tech system. In 1986 Entech employed 42 people. Today, they employ 135. Their growth has been primarily dependent upon a philosophy that can only be characterized as "getting close to the customer." This trial and error approach has been of great value.

Entech initially spent a lot of time knocking on doors, presenting their idea of what the customer wanted, and then receiving corrections from the customer. Through the process of "getting close to the customer" they have developed a strategic alliance. When initially assessing the market, Entech realized that the opportunity for a return on its investment would only come if the widget was successfully integrated into their customer's high tech system. Therefore, in mapping out their $R \& D$ and marketing strategies, they anticipated the final goal not as production of the widget, but as utilization of the widget as a critical component of the customer's high tech system. That last phase of their plan has been financed by the customer. The customer's motivation in this process was sparked by the fact that the use of the widget in a new high tech system would open up new markets.

Funding has always been a challenge to Entech. They initially received equity financing from an overseas firm. The foreign investor provided the cash and Entech provided the technology. This initial funding enabled them to conduct their preliminary work with customers. However, funding problems on the part of the investor, coupled with their early success, led Entech to buy back its equity.

For Entech, the hardest part of the commercialization process has been obtaining good data on performance in actual field locations. They had to expend a lot of effort to gain permission from potential customers to install the equipment, obtain good field data, and convince them to continue running the tests.

At one point, when reviewing their strategies for growth, Entech considered getting into the manufacturing of the high tech instrument. However, when they assessed this market they learned that 20-24\% of the gross sales of the instrument market were spent on sales promotion and service. Upon reflection Entech decided that they did not wish to develop a large sales force or customer service department or pay for the costs involved with developing the high tech item themselves. They made a strategic decision to continue 
manufacturing the widget and not get into the high tech instrument business. They only spend $5 \%$ of their gross dollars on sales and services, have a smaller staff, and need only one location.

Entech presently has 14 on-going program, including one SBIR program. They must ramp staff up and down quickly and plan shifts for their staff between programs, sometimes anticipated over a year in advance. Staff members are shifted to support funded programs. Entech has commercialized one model of widget, obtained a "design win" on another, and applied for three patents. Its management feels that the strategies being followed are allowing company growth while staying within the constraints of prudent financial management.

\section{EQUITY INVESTMENT: VENTURE CAPITALISTS AND BUSINESS ANGELS}

\section{Definition}

Use of the phrase "equity investment" indicates the exchange of a percent ownership in a business in exchange for financial resources. Equity investment is to be contrasted with debt investment in which a company borrows money to be repaid in exchange for principal and interest.

\section{When should venture capital be considered?}

In an excellent book entitled Who's Whe of Venture Capital. David Silver indicates those conditions under which venture capital is desirable. His decision tree is based upon how many Demonstrable Economic Justifications (DEJ's) your company possesses. If all eight are present, Silver maintains that you probably don't need venture capital. If you have less than four, your company has a high likelihood of failure-even with venture capital. If you fall somewhere in between, venture capital would be an appropriate consideration.

Silver's eight DEJ's are listed below:

DEJ \#1: Existence of Qualified Buyers. The buyers know they have a problem; they know they must pay for the solution; they are able to pay for the solution; and require minimal buyer education.

DEJ \#2: Existence of Competent Sellers. The organization has highly competitive, competent salespeople - "The Engine."

DEJ \#3: Homogeneity of Buyers. Little tailoring or customization of the product is required.

DEJ \#4: Large Number of Buyers.

DEJ \#5: Lack of Institurionalized Barriers to Entry, making it easy to get product to customers. No regulatory body affects buying or selling behavior

DEJ \#6: "Hey, it really w'orks." The product/service receives good word of mouth advertising.

DEJ \#7: Optimum Cost/Price Relationship.

DEJ \#8: Invisibility of New' Company. It operates quietly, without fanfare. It gains momentum before it can be easily copied. 
Another way of determining when you need venture capital is to consider the types of funding that venture capitalists provide. There are three primary levels of financing with various subdivisions (See Figure 5). It should be recognized that there is some variation in how these terms are used. It would be advisable to seek clarification of terms in a conversation. The definitions which follow were taken from Pratt's Directory to Venture Capital, which is a standard reference in the industry.

FIGURE 5: Stages of venture capital financing

\begin{tabular}{|c|c|c|c|c|c|}
\hline Seed Financing & Start-up Financing & $\begin{array}{c}\text { First Stage } \\
\text { Financing }\end{array}$ & $\begin{array}{c}\text { Second } \\
\text { Stage } \\
\text { Financing }\end{array}$ & $\begin{array}{c}\text { Third Stage } \\
\text { Financing }\end{array}$ \\
\hline $\begin{array}{c}\text { Market Research } \\
\text { Assemble Team }\end{array}$ & Launch & $\begin{array}{c}\text { Prototype } \\
\text { PreProduction } \\
\text { Productlon }\end{array}$ & $\begin{array}{c}\text { Full Scale } \\
\text { Manufacture } \\
\& \text { Sales }\end{array}$ & $\begin{array}{c}\text { Shipping } \\
\text { Product; } \\
\text { Not yet } \\
\text { profitable }\end{array}$ & $\begin{array}{c}\text { Profitable and } \\
\text { Expandlng }\end{array}$ \\
\hline \\
\hline
\end{tabular}

\section{Early Stage Financing}

Seed Financing: A small amount of money is used to qualify for startup financing. Such monies are usually spent on product development, market research, business plan development, and assembly of a management team.

$R \& D$ Financing: Most likely a limited partnership arrangement which provides a lax advantage to limited partners as well as a share in the profits if the product is successful.

Startup Financing: This level of financing is typically provided to those who are "ready to do business," having completed the basic qualifiers indicated under seed financing.

First Stage Financing: Funding needed to initiate full-scale manufacturing and sales.

\section{Expansion Financing}

Second Stage Firancing : Operating capital for a company that is shipping product, although it may not yet be profitable.

Third Stage or Mezzanine Financing: This level of financing is provided for companies that are beginning to turn a profit and require funding for expansion of various functional elements.

\section{Bridge Financing}

This level of funding is typically sought when a company plans to go public within six months to a year. The term may also be used to refer to interim funding in other situations.

The percentage retum an investor expects and the percentage ownership he will demand, varies with the level of tunding sought. When a technology or business is new and unproven, it presents the greatest risk to the investor. As Gordon Baty of Zero Venture Capital describes it, "Seed funding" clearly represents "the other side of the tracks" and "looks like a rough neighborhood indeed." Those investors who are willing to provide funding under such conditions will expect the highest return. As your sales increase and you become an established entity, risk to the investor decreases. Thus, the percentage 
return decreases. If you wish to maintain as much control as possible, you might hold off seeking venture capital until later in your development cycle.

Venture capital firms vary greatly in the types of funding which they provide. Such differences are clearly indicated in Pratt's Guide to Venture Capital. In general, they prefer to invest in companies which will show a strong return in three to five years. However, there are some venture capitalists which specialize in early seed funding. As a rule, most venture capital firms keep an assortment of investment levels in their portfolio which favors later stage financing when risk to the investor is substantially less. When providing early seed funding for technology development, it is common for venture capital firms to seek corporate co-investors. This increases the likelihood that there will be a customer for the technology when it is developed.

Process: In approaching a venture capital firm, it is preferable to have an introduction made on your behalf by an accountant, lawyer, banker, venture capitalist, entrepreneur, or other trusted party. (These are your champions). You should then call the firm and ask if they would be interested in receiving a copy of your business plan to review. After reading the plan, if they are interested in pursuing the opportunity any further, the venture capitalist will ask you to visit or will make a site visit. If interest continues he will conduct "due diligence" to independently assess the merit of the business, that is, the investor will call potential customers, distributors, and suppliers in order to gain as much information as possible about the market. He will also call university research organizations for technology benchmarking.

It is often said of venture capitalists that they would rather have a Grade A management team with a Grade B business plan, than a Grade A plan with a Grade B team. This statemient is not intended to minimize the importance of a good business plan, but to indicate that if you are seeking venture capital, you will need a strong management team. A strong managernent team is one which "Keeps a healthy balance sheet; has a clearly focused strategy; and is realistic about marketing."(Preston, 1990). The team plays very strongly in the venture capitalists decision making process. If your team is uneven, it is likely that they will require the addition of specific players to your team to "rev up the engine."

If a venture capitalist is investing large sums of money in your company it is likely that he or she will require a seat on your Board of Directors and will take a strong interest in your company's success. John Preston of MIT indicates that the larger the venture capitalists' investment, the stronger their interest. This is advantageous, as the investors will want to maintain their track record of portfolio success and will work harder on your behalf if they have invested more heavily in your firm. The venture capitalists become an important part of your team. You should assess them to the same extent that they will assess you. Ask for references; ask for the names of other entrepreneurs in their portfolio that you can contact; and ask about their contacts in your industry and their experience with this technology. Look for synergy and the value that they can add.

\section{Who provides equity investment?}

Venture Capital Firms, business angels, and the venturing arm of large corporations all provide equity investments.

Venture Capitalists: There are over 2,000 venture capital firms in the United States. Venture capitalists manage and invest other people's money. Over $50 \%$ of venture capital money comes from pensions funds. They are extremely cautious. Venture Capital firms tend to specialize by geographic location, type of tec' inulogy/product, and size of investment. Various sources can be consulted to find out about the funding behavior of Venture Capitalists (VC's). These include : 
Pratt's Guide to Venture Capital Sources

Venture Economics, Inc. 1991.

(617) 449-2100

Who's Who in Venture Capital

A. David Silver

New York: John Wiley and Sons, Inc. 1987

Some of the better venture capital firms to approach when looking for seed funding are listed below. Complete addresses and other details are in Appendix A.
$\mathrm{AV}=\quad$ Ampersand Ventures
$A R D=A R \& D$
GFL $=$ Greylock
$\mathrm{MV}=$ Menlo Ventures
SHV $=$ Sutter Hill
$T^{\prime} \mathrm{VI}=$ Technology Venture Investors
$\mathrm{VA}=$ Venrock Associates
$\mathrm{ZSC}=$ Zero Stage Capital

Table 2: Industry preferences* of selected seed venture capital funds

$\begin{array}{lllllllll} & \text { AV } & \text { ARD } & \text { GFL } & \text { MV } & \text { SHV } & \text { TVI } & \text { VA } & \text { ZSC } \\ \text { Communications } & \text { X } & \text { X } & \text { X } & \text { X } & \text { X } & \text { X } & \text { X } & \text { X } \\ \text { Computer Related } & \text { X } & \text { X } & \text { X } & \text { X } & \text { X } & \text { X } & \text { X } & \text { X } \\ \text { Consumer } & & & \text { X } & \text { X } & & \text { X } & & \text { X } \\ \text { Distribution } & & & \text { X } & \text { X } & \text { X } & \text { X } & \text { X } & \text { X } \\ \text { Electronic Components } & \text { X } & \text { X } & \text { X } & \text { X } & \text { X } & \text { X } & \text { X } & \text { X } \\ \text { Energy/ Natural ResourcesX } & \text { X } & \text { X } & \text { X } & & & \text { X } & \text { X } \\ \text { Genetic Engineering X X } & & \text { X } & \text { X } & \text { X } & \text { X } & \text { X } & \text { X } \\ \text { Industrial Products/Equip. X } & \text { X } & \text { X } & \text { X } & \text { X } & \text { X } & \text { X } & \text { X } \\ \text { Medical/Health Related X } & \text { X } & \text { X } & \text { X } & \text { X } & \text { X } & \text { X } & \text { X } \\ \text { OTHER } & & & & & & & & \text { X } \\ \text { Agriculture } & & & & & & & & \text { X } \\ \text { Education } & & & & & & & \\ \text { Finance and Insurance } & & & \mathrm{X} & & & & \\ \text { Publishing } & & \mathrm{X} & & & & & \text { X } \\ \text { Specialty Consulting } & & & & & & & \text { X } \\ \text { Transportation } & & & \mathrm{X} & & & \end{array}$

* See Pratt's Guide to Venture Capital for more detailed information on topics of interest within industries. 
Other venture capital firms tend to be interested in significant problem (P) solution, problems such as "finding a cure for cancer." Silver refers to these as "Big P" companies. They include:

\author{
ABS Ventures \\ Advanced Technology Ventures \\ Allstate Insurance Co. \\ Citicorp Venture Capital, Ltd. \\ Clarion Capital Corp. \\ Columbine Venture Fund, Ltd. \\ Fairfield Venture Partners \\ Golder, Thoma, and Cressey \\ Greater Washington Investors, Inc. \\ Hambrecht and Quist Venture Partners \\ Hambro International Venture Fund \\ InterWest Partners \\ The Lambda Funds \\ Matrix Partners \\ Nazem and Co. \\ New Enterprise Associates \\ Oak Investment Partners \\ Pathfinder Venture Capital Fund \\ Pioneer Ventures L.P. \\ Plant Resources Venture Fund \\ The Southwest Venture Partnerships \\ Sprout Group \\ Sutter Hill Ventures \\ Technology Venture Investors \\ Vista Technology Ventures
}

Pratt's Guide can be consulted to determine the content specialty and the geographic preference of these firms.

John Preston, the Director of MIT's Technology Licensing Office recommends looking for the following in a venture capital firm:

(1) their track record in building successful companies;

(2) their network of connections with firms that would make good strategic partners;

(3) the level of personal involvement they are willing to devote to the new company;

(4) their access to moncy and long term vision. (Preston, 1990).

Don't be shy in requesting this information. Ask the investor for references, no matter how big the organization or what its reputation may be.

Venture capital trends: In 1978 the venture capital industry was valued at $\$ 3.8$ billion. In 1989 it was valued at $\$ 33$ billion. Approximately $\$ 4$ billion dollars of the latter were spent in carly stage financing. Competition for venture capital funds is very high, requiring that companies interested in venture capital must be betier prepared.

Business angels: The term "business angel" comes from Broadway. This term was initially applied to patrons who would back big broadway shows. Nowadays the term refers to an informal group of investors. They are typically self-made men with large net 
worth. There are NO dicurorles of angels and there are no public records of their transactions. Business angels have "street smarts" and can bring both moncy and know-how to a situation. Business angels exist in all parts of the courtry and invest in all types of companies that have the possibility of creating value. They are interested in capital gains income. It is common to seck seed funding from angels and then go to venture capitalists for later stage fïnancing.

Process: When looking for a business angel, look within 50 miles of home. Investment is not a full-time endeavor for business angels. They tend to be involved with other things. Look on community boards; develop a clipping file of individuals in your community. Look for people who are familiar with your field. Another source of leads is your CPA, lawyer, and local venture capitalists. If you are not sure how to find out about local venture capitalists groups, contact your local Chamber of Commerce.

Business angel trends: The pool of business angels is far greater than the pool of venture capitalists. It is estimated that there are 250,000) active angels and that the total pool of money that they have to invest is between 100 and 300 billion. It is estimated that they have backed between 50,000 and 100,000 companies. 29\% of angel funding is provided at the seed stage as compared to $6 \%$ of venture capital funding (William Wetzel, 1989; Frank Hughes, 1989).

Venture arm of large corporations: The term "corporate venturing" refers to a variety of approaches that large corporations use to establish a relationship with an emerging business. "Corporate venturing" refers to corporate venture investments, joint ventures, and strategic alliances. Corporate venture investments are sometimes made by a subsidiary which operates very much like an unaffiliated venture capital fund. Their investments, however, tend to be in products, markets, and technologies which relate to the business with which the parent business is involved. Their motivation in investment is often to incubate a potential acquisition or to obtain special licensing agreements, research contracts, or volume purchase agreements.

A corporate venturing partner can be extremely advantageous. The larger corporation is often able to make numerous resources available to the smaller firm to enhance its growth. Association with a large company also provides face validity and often access to important customers.

Valuation: The valuation process is complex and a subject unto itself. You should consult various sources to obtain a good understanding of this. However, there are some general rules of thumb:

(1) the more developed your business (all elements: product, market/sales, management team) the greater its value.

(2) The more developed your business, the lower the risk.

(3) The lower the risk; the less equity you will need to exchange for capitalization.

If your technology, the market, and your business are undeveloped you constitute a high risk venture.

When "structuring a deal" you will hear the term "pricing." Pricing refers to the amount of equity the investor will expect in exchange for his investment. In general, such pricing is a reflection of two items: risk and investment objectives. As indicated above, unproven management teams, unproven markets, and certain $\mathrm{R} \& \mathrm{D}$ problems are high risk. By contrast, experienced management teams, well understood markets, and established technologies are lesser risks. The investment objectives of investors varies. However, 
venture capitalists will expect a greater return for their investment than they can receive in relatively risk-free investments such as bonds and real estate. Common return on investment (ROI) objectives range from "ten times their investment in five years for startup companies to as low as five times their investment in five years for more mature companies (less risky). (Deloitte, Haskins, and Sells, 1988, p. 56)."

Potential investors will start by reviewing your business plan and your after-tax earnings projected out five years. Usually entrepreneurs tend to overestimate the potential, so investors will modify the projections based on their assessment of the risks involved, thus lowering the projected after-tax earnings. They will then consider their desired rate of return and the potential future value of the business at "cash-out" or potential sale of the business. The latter is calculated by examining the selling price of comparable businesses represented as a multiple of current earnings.

The exit: During the time that the venture capitalist works with you, his primary objective will be your company's growth. Only if your company grows will he realize the anticipaled Return on Investment (ROI). The exit strategy three to five years down the road is the way the venture capitalist makes his money. Three options are most commonly taken:

(1) Going public,

(2) Purchase by the company or entrepreneur,

(3) Sale of the company to another company, or

(4) Finding a new investor.

A good discussion of these options is found in The Venture Capital Handbook by David J. Gladstone.

Example: XYZ Technologies received a SBIR Phase II award several years ago in an area that was related to its core business. Due to a lack of laboratory facilities, the SBIR work was conducted at the facility of XYZ'S subcontractor, a university. During the project timeframe, $X Y Z^{\prime}$ 's core business grew and the SBIR technology became only a small percentage of its sales.

As part of its financial strategy, Joe, the President of XYZ Technologies, decided to seek venture capital. XYZ developed a business plan and started networking. At a conference foe attended on corporate venturing, a speaker from a venture capital(VC) firm mentioned an interest in the field of the technology that XYZ had wor!:ed on under the Phase II award. After the presentation, Joe approached the VC spokesperson and talked about the SBIR technology. In so doing, he spoke of XYZ's core business area. It quickly becane apparent that the venture capitalist was more interested in the other work that $X Y Z$ was pursuing. Joe quickly changed gears and began discussing their other projects. He offered to send $X Y Z$ 's business plan for review. Approximately six months later, $X Y Z$ Technologies closed on venture capital funding with VC.

Presently XYZ Technologies does not have the funding, laboratory facilities, or the skills mix to pursue the SBIR development work in an aggressive fashion. The venture capital firm, interested in the success of $X Y Z$, has kept joe informed of other opportunities, including overseas licensing opportunities for their intellectual property developed within the area funded by the SBIR grant. XYZ is looking for a partnership arrangement that will enable them to more actively pursue development in the SBIR-related technology. 
XYZ Technologies tried to review and select only the premier venture capital firms for presentation of its business plan. It only wanted a firm which had a background and a thorough understanding of $X Y Z$ 's field of business. VC matched those criteria and $X Y Z$ has been pleased with their working relationship.

\section{INITIAL. PUBLIC OFFERING (IPO)}

\section{Definition}

An Initial Public Offering (IPO), also called "going public," marks the transition from being a privately-held company to a public company. This process is regulated by the Securities and Exchange Commission (SEC). It is a lengthy and expensive process. This topicys discussed in great detail in Sutton and Benedetto's 1988 publication entitled Initial Public Offerings: A Strategic Planner for Raising Equity Caplial.

\section{When should a company consider an IPO?}

This option is most often considered as a means of raising capital or as an exit strategy for a previously made venture capital investment.

\section{What are the advantages of an IPO?}

Financial stability. When it is no longer viable to expand through borrowing, IPO is a viable alternative to consider.

Prestige. Publicly traded companies are newsworthy. They receive much more publicity, thus enhancing the name recognition of the company among customers, competitors and suppliers.

Employee Stock Compensation Incentives. The availability of stock options makes it possible for you to provide incentives to attract and keep good people.

Enhanced Credit Worthiness. A publicly traded company has more credibility with creditors, customers, and suppliers.

\section{What are the disadvantages of an IPO?}

Expensive. The expense associated with going public is exorbitant, costing between $\$ 50,(0) 0)$ and $\$ 5(0), 000$ depending on the size of the offering. These costs are for paying attorneys, accountants, and underwriters for the preparation of all the special reporting documents that are required by the SEC.

Disclosure of information. SEC regulations require filing of all sorts of information.

Salaries, planned mergers, and your financial performance all become a matter of public record. You lose some competitive advantage in the process.

Many bossies Your stockholders will expect the company to perform and increase their carnings per share.

No more venture capital. Once you "go public," certain sources of tinancing are no longer available to you, such as venture capital.

New management. Managing a company that is publicly held will require that management redefine its priorities. Management will need to spend much time interfacing with analysts, stockholders, and the press. Management will also lose some of its latitude in decision making, as some key decisions will need to be made by the stockholders.

Process. The process is extremely complex, costly, and lengthy. Refer to Sutton and Benedetto's work for a good discussion of the topic. 


\section{STRATEGIC ALLIANCES/TEAMING ARRANGEMENTS}

\section{Definition}

Strategic alliances are collaborations that do not require debt or ecjuity transactions. The data in Figure 6 depicts the preferred lypes of alliances as noted by Venture Economics in 1990 and February 1991. Marketing strategle alliances were clearly the most common, with $R \& D$, licensing, and joint ventures following in descending order, Marketing and $R$ \& D Agreements are defined below. Licensing and joint ventures are described in greater detall in the following sections.

FIGURE 6: Preferred types of alliances

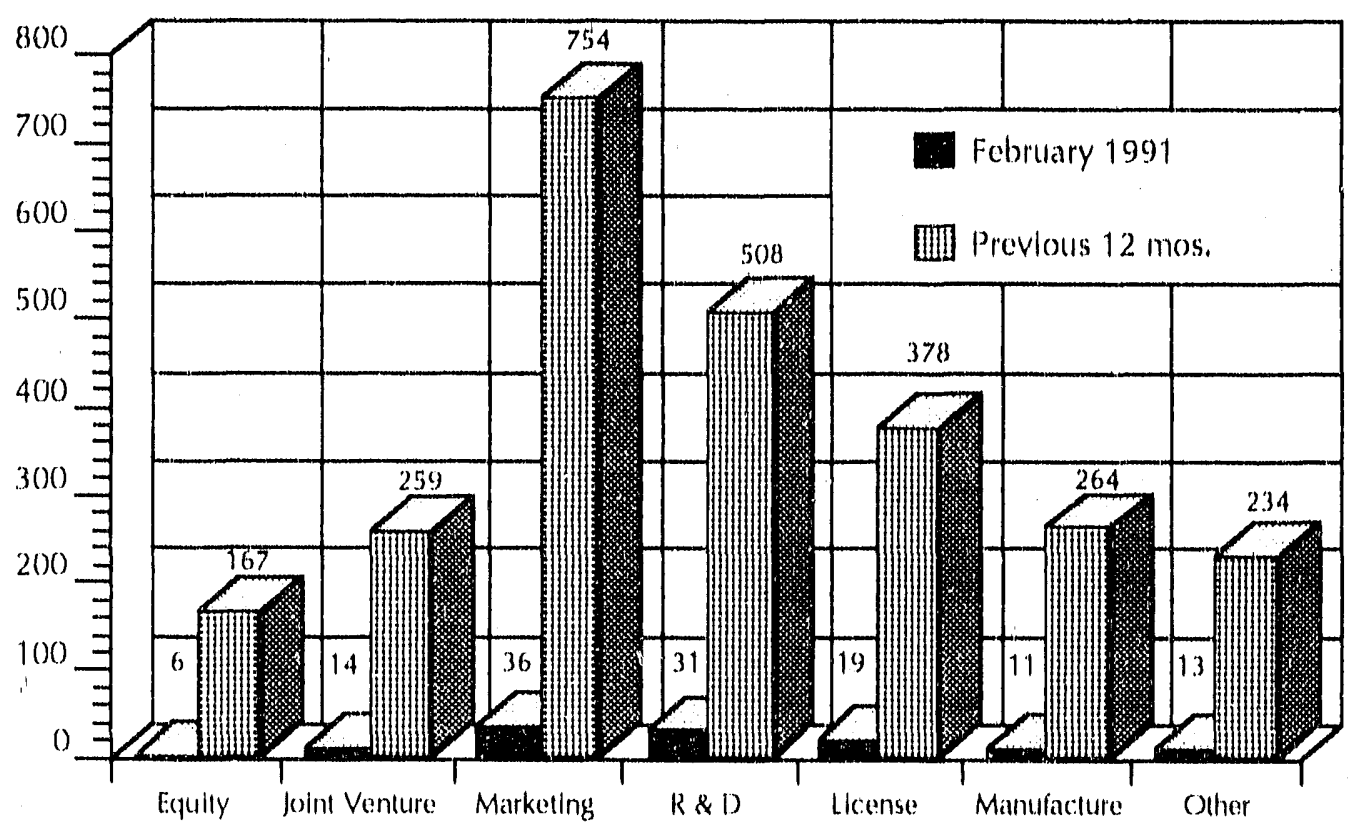

Source: Corporate Venuring News. March, 1991. Reprinted with permission of Venture Economics

Marketing/Distribution Agreement. This is a contractual relationship between two firms where one company is responsible for marketing, sales, and possibly service of the products of another in certain geographical markets. An example of this arrangement would be Xerox and Fuji Xcrox. Fuji Xerox is responsible for marketing, sales, and service of Xerox products within the Pacific Basin.

Research/Development Agreement. This is a contractual agreement whereby firms pool their research and development elforts or funding to achieve a goal that they would be unlikely to achieve alone. Ownership rights to the developed technology/products are detailed in the agreement. An example of this arrangement would be the airbus developed by Boeing and Northrup.

\section{When should one form a strategic alliance?}

In a recent ariicle, Kenichi Ohmae (1989) makes a strong case for strategic alliances, arguing that they should be a part of every good strategist's repertoire. A globalization of customers based on a convergence of needs and preferences requires that strategic alliances exist. These preferences transcend national boundaries. Another compelling force is that fixed costs are increasing in every industry. "In a variable-cost environment, the primary focus for managers is on boosting prolits by reducing the cost of materials, 
wages, and labor hours. In a lixed-cost onvironment, the focus switches to maximizing marginal contribution to lixod cost-that is, to boosting sales (Ohmac, 1989, p. 147),"

\section{With whom should one form a strateglc alliance?}

In looking for strategic allances ono must clearly look for potental partnors that have complementary skills/ resources and which can readly expand onc's customer base and/ or other capabilities.

\section{What process should one follow in developing an alliance?}

Ohmae maintains that a geod allance is llke a good marriage, and recuulres that respect and fair play characterize the relationship. He persuasively argues against equily arrangements, as they tend to be used as instrument of power and for distancing and blaming others. Ohmac's recommendations for successful collaboration include:

- Making a personal commitment to the alliance,

- Mutual respect and trust.

- Taking time to develop and maintain the relationship,

- Clarlfying the relationship In contractual form and then quickly putting the contract away,

- Clarifying mutual expectations and timeframes,

- Maintaining an awareness of a partner's problems,

- Learning to interpret particular responses in a culturally approprlate way,

- Recognizing a partner's Independence, and

- Celebrating successes together.

Figure 7 reflects the number of allances formed in 1990 that involved US partners only or international partners. As can be seen, both US and international strategic alliances are used frequently, In the next section particular attention will be given to two forms of strategle alliance: licensing and joint ventures.

\section{FIGURE 7: Alliances involving US or international partners}

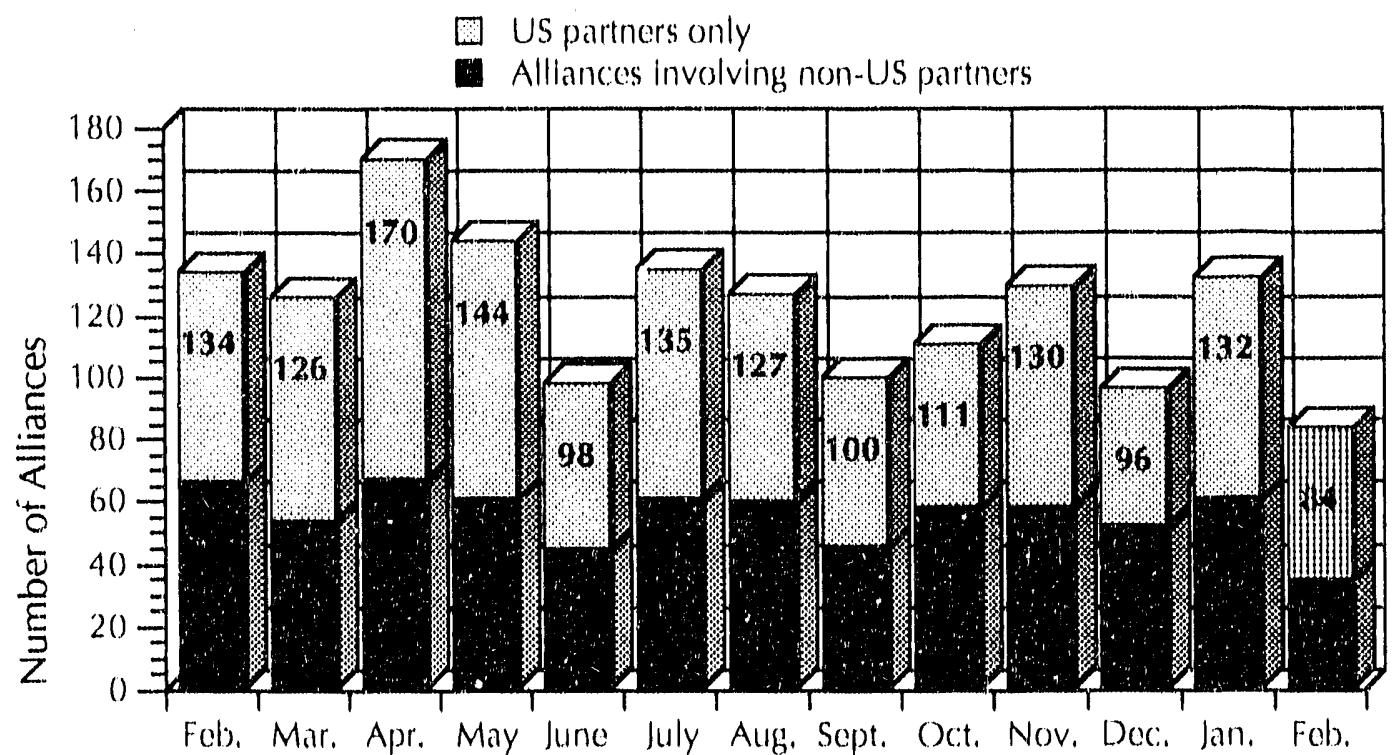

Source: Corporate Venuring News. March, 1991. Reprinted with permission of Venture Economics 


\section{LICENSING}

\section{Definition}

Licensing is a modified conditional sale of an intellectual property right. Any form of intellectual property can be licensed, including patents, copyright, trademarks, trade secrets, and 'know how'. One is well advised to seek protection for all forms of intellectual property. In the technology area, patent protection is of primary importance.

Figure 8 shows the percentage of US patents issued in 1990 to individuals from various countries.

\section{FIGURE 8: US Patents issued (1990) by country}

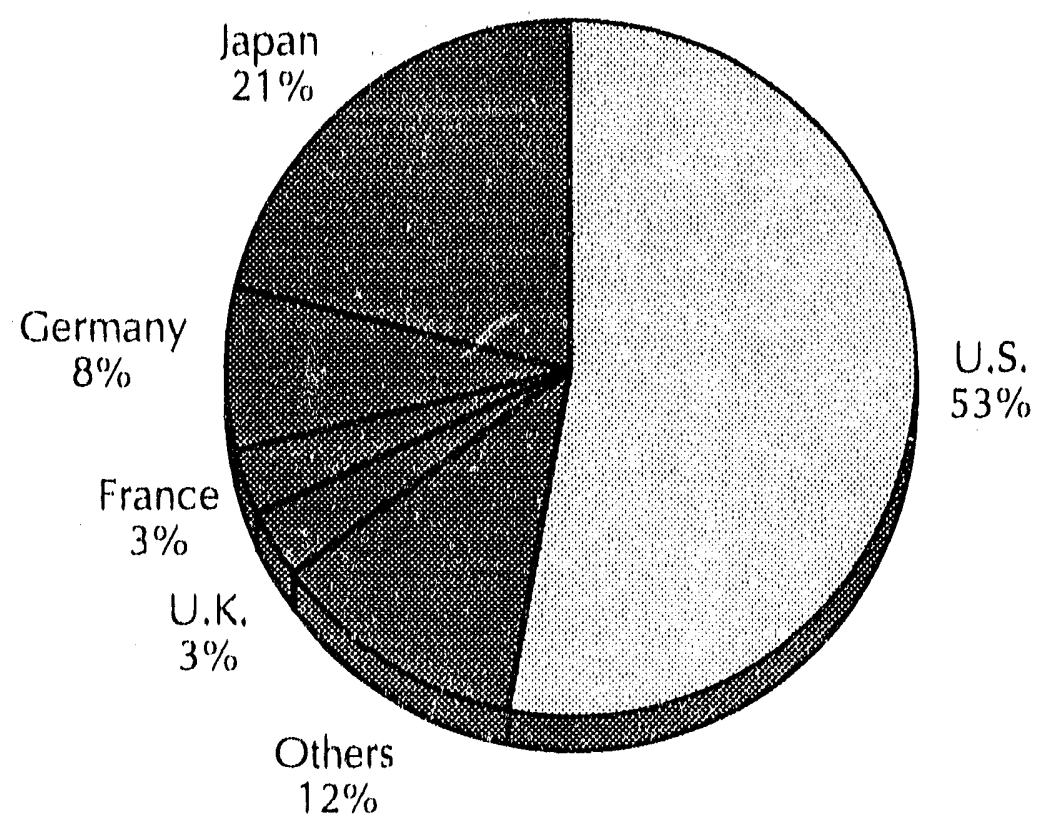

As patent protection precludes others from manufacturing the invention within the US and its territories, one could be prohibited from manufacturing in the US if someone else is granted a patent before the sclentist lakes action. Patenl It Yourself, an excellent book written by Patent Attorney David Pressman, provides a clear description of the entire patent process. It is highly recommended reading.

Scientists too - frequently fail to protect their technology. In a recent issue of Technology Access (April 1991) the story of Dick Post was recounted. Post, a physicist at the Lawrence Livermore National Labs (LLNL), Invented the cuadrupole mass spectrometer in the 1950's. He published a paper on his findings, but did not patent it due to restrictions that existed at that time prohibiting scientists in federal labs from collecting royalties. "The market for mass spectrometers is now in the neighborhood of $\$ 500$ million per year, and the invention has made billions for companies since its LLNL. inception. The lab never saw a penny..." (Longerbeam,p. 3)

\section{When should one consider licensing?}

If a company's strength and delight come from technology development, rather than from development of a manufacturing company, It would be well advised to consider licensing its technology, Licensing can also be used as one of many funding options used by a company. Intellectual property is valuable. 


\section{What process does one follow in licensing?}

The negotiation process is quite lengthy and involves numerous steps:

(1) Disclosure

(2) Non-Disclosure (also refierted to as Secrecy Agrecment)

(3) Option

(4) Licensing Agrecment

These steps move a potential licensor from no commitment to a commitment. A general rule of thumb is to present only enough information at each point to shift the potential sponsor to the next level of commitment. "Ponple sell, products don't." In other words, if you want to increase the likelthood of obtaining a licensing agreement, you must also increase the frequency of face to face meetings. There is no substitute for developing a relationship with a potential sponsor.

Disclosure: In the process of transferring technology, one begins with a disclosure. You need to disclose as much as necessary in order to get their interest. The disclosure should be short, descriptive, and non-confidential. Don't give away any secrets! The person with whom you are speaking probably receives several hundred disclosures a year. To make yours stand out, it is best to present objective, measured data to substantiate your claims. Place your item in a comparative position at the outset.

Non-disclosure: The follow-up to a disclosure usually involves a Non-disclosure agreement, also called a confidentiality agreement, or a secrecy agreement. The Non-disclosure agreement must define what it is that you are going to call confldential. This agreement limits you as to what you can tell the company and limits the company as to what it can use.

A good Non-disclosure agreement should contain the following items:

a. Time limit. No contract is valid without a time frame. There are different industry standards which vary between three and ten years in length.

b. The agreement must exclude (1) information which is already in possession of recelver, (2) information which is in the public domain, (3) iniormation which can be obtained from a third party, and (4) information that is subsecquently developed independently.

c. Use of Information: The use of information must be restricted.

d. You should include the phrase "NO IMPLIED LICENSE."

e. SET A TIME LIMIT for the receiver of the information to complete the task in question.

Once both parties have signed the Non-disclosure agreement, then you can make your disclosure of confidential information. Don't disclose everything at once! Dr, Davis, of the Licensing Executive Society advises that you proceed in a step-wise fashion, withholding critical information until you have confidence that they have interest (Davis, 1989). Don't withhold negative data; as that may come back to haunt you. It may cause lack of trust and give rise to questions of integrity. At the same time be aware that negative experimental results can constitute a "trade secret." 
Option: The next document is referred to as an Option to License. This document provides a period of time for extended evolution or development. It provides a method to recelve some payment and informs the recelving company of those items to which they hold rights.

The most important elements of an Option to license are:

(1) Timing

(2) Payments

(3) Performance Requirements: The performance requirements are vital. Specify everything that needs to be stated to assure that they proceed with development. Outline the program of development. It is warranted to put everything in writing that you want to have happen. For example, the dollar amount to be spent in market rosearch, the size of the team to work on this project, and specific milestones. Non-compliance with the performance requirements of an Option to license, volds the agreement. Specificity of performance requirements is of paramount importance.

Licensing Agreement: The final license is the sale that has certain limitations and condithons which are carefully expressed in the Licensing Agreement. The item licensed must have value and be worth more to the buyer than the seller. The important elements of a Licensing Agreement include:

Parties Involved: Be careful as to who is on the other side of the table: the parent company, the subsidiary, etc. You want your contract to be with the highest entity that you can get on your side. Make sure that you represent all the parties involved (co-inventors).

Definitions: This makes writing the rest of the contract easy. Define what you're licensing (specify patent numbers and registration numbers of copyrights and trademarks, as appropriate), Be sure to indicate if the licensing agreement is exclusive, sole, or nonexclusive. The tem "Sole" implies that it is an exclusive arrangement but excludes the inventor who can continue to do whatever he or she wants, but precludes licensing to another (Davis, William, 1989).

Payment Form: Arc you getting a license fee up front? If the licensee pays all of his money up front, that transfers all the risk to him. A license should be a "win-win" situation, and one of the most equitable payment forms is a royalty payment. The manner in which royalties are calculated varies from industry to industry. From the perspective of the person seeking to license, the most desireable form of payment is a royalty based on units sold or gross sales. Frequently, royalties are also based on production margin or net profit. Be sure you understand the basis on which royalties will be calculated.

With Whom: When you license your technology or product, you should court an entity that you believe has the capability to market ard distribute your product on a large scale. As royalties are based on net sales, the company to which you license must have the "engine" required to sell the product in volume. If you select a company poorly, you will not realize royalties of substance on your Licensing Agreement. You should not assume that a Fortune 500 company is a safe haven by virtue of its size. Conduct your own corporate intelligence to assess the likelihood that your technology would be developed well when licensed.

Before signing a licensing agreement, you should conduct some corporate intelligence on the company in question. The types of things to consider are its earnings, what the analysts are saying about the company, legal proceedings pending, major acquisitions, and change in control. On publicly traded companies, such information can be obtained by contacting the SEC or by visiting their public reference rooms in Washington, Chi- 
cago, or New York. You can request an Annual Report, Prospectus, 10-K Report, 10-Q Report, or an 8-K Report. These are forms that the securitles exchange requires that all publicly-traded companies file. See Table 3 for a description of the content each contains.

Table 3: Description of SEC reporting documents

\begin{tabular}{|c|c|}
\hline $\begin{array}{l}\text { Reporting } \\
\text { Document }\end{array}$ & Description \\
\hline $10-K$ & $\begin{array}{l}\text { Made within 90 days of company's } \\
\text { fiscal year legal proceedings } \\
\text { - identifies principal products, } \\
\text { services, distribution channels, } \\
\text { competitive factors, intellectual } \\
\text { property, licenses, environmental } \\
\text { impact, size of R\&D }\end{array}$ \\
\hline $10-Q$ & Filed quarterly \\
\hline 8-K & $\begin{array}{l}\text { Reporting made within } 15 \text { days of } \\
\text { significant events } \\
\text { - acquisitions } \\
\text { - bankruptcy } \\
\text { - resignations }\end{array}$ \\
\hline
\end{tabular}

Your request should be sent 10:

Securities and Exchange Commission

Public Reference Branch

Stop 1-2

450 Fifth Street, NW

Washington DC 20549

(202) 272-3607

Some other sources to consult when looking for ways to surface background information on companies of interest can be found in Find It Fast. Everybody's Business; and the US Department of Commerce Library (202-377-2161).

What you are trying to avoid is a company that is in turmoil, a company with poor marketing and distribution capabilities, or a company that is unwilling to comply with your request for stringent performance criteria in the Options agreement. Consistent champions and sponsors for your technology and product are important at this stage as well, to assure that the company to whom you've entrusted "your baby" is capable of fulfilling its obligations.

Valuation: The royalties paid vary from industry to industry. However, in general they are in the $5-10 \%$ range based on net sales.

Trends in Licensing: "Licensing out" is increasingly boing used by Universities and Federal labs as a means of supplementing income to the organizations. One should anticipate that it wili take a few years before there is a royalty stream of substance. 
Example: As a routine element of corporate intelligence, scientists from Fortune 500 companies monitor the trade journals to keep abreast of research in their company's fields of interest. It was through this process that TechnoCense, Ltd. , was approached by a large corporation.

TechnoCense, Ltd. , is a contract $R \& D$ firm that has received numerolis $S B I R$ grants. They have made it a poicly to protect their intellectual property and also to publish the results of their research. This policy worked to their advantage in their negotiation of a Research and Licensing Agreement with the Fortune 500 firm.

The first face to face meeting with TechnoCense's staff was initiated by the For:une 500 firm and involved the technical staff from both companies. At the site visit, the first order of business was to clarify the needs of the potential customer. TechnoCense's management subsequently spent time discussing what they would be willing to give up in exchange for $R \& D$ finds. Over a 9 month period, management and attornies from both sides negotiated a Research and Licensing agreement that would provide TechnoCense $100 \%$ of the required $R \& D$ dollars, as well as royalties on a wide range of their patents.

The licensing agreement that TechnoCense negotiated was unusual and has been adopted by the firm as a strategy they wish to pursue in other markets. The Fortune 500 company in question was interested in a very narrow application of the intellectual property. Therefore, what Technocense negotiated was a limited, exclusive licensing agreement that would provide the Fortune 500 company rights to past, present, and future patents for a period of time in this narrowly defined market niche. In exchange, they received $100 \%$ of the funds for continued $R \& D$ in this area, as well as the rights to a royalty stream resulting from their patents. TechnoCense retained for itself the option to develop a small deliverable within this narrow market niche, as well as the rights to license the same intellectual property to firms interested in different applications.

TechnoCense has been very pleased with this arrangement and is looking for opportunities to develop multiple, licensing agreements with other firms in other market niches.

\section{JOINT VENTURES}

\section{Definition}

A joint venture is a separate legal organization formed when two companies wish to collaborate for mutual benefit (Deloitte, Haskins, and Sells, 1988). This is a form of strategic alliance, as both of the host organizations retain their separate identities.

\section{When should one consider a joint venture?}

If your SBIR company is growing rapidly, but you lack the resources required to penetrate the market, a joint venture may be highly appropriate. Table 4 contains a brief description of the most commonly considered reasons for joint venturing.

TABLE 4: Motivation for joint venturing

\section{Internal}

1. Financing

2. Cost and risk sharing

3. Obtain resources

4. Information exchange

5. Personnel interchange

\section{Strategic}

1. Exploit synergies

2. Technology transfer

3. Diversifications

\section{Competitive}

1. Preempt competitor

2. Access to customers

3. Pioneer development of new industries 


\section{With whom should you form a joint partnership?}

The process of locating a good partner with whom to joint venture also requires some corporate intelligence. If the company is publicly traded, frequently you can find a listing in the company's annual report of the joint ventures with which it is involved. Corning, for example, lists 16 joint ventures in its annual report and also indicates \% ownership. Corning's ownership varies between 20 and $50 \%$. If you want to obtain more information about what it is like to joint venture with a specific company, you can contact those who are already involved with such a relationship. Annual reports and SEC reports are good resources to consult for locating the names of joint ventures involving specific companies.

Points of primary concern in joint venturing include culture clash, control, decision making processes, and the resources that the other company is bringing to the table (marketing, distribution, R \& D development funds). Michael Geringer (1988) indicates that his research suggests that joint ventures are more successful when formed between companies of comparable size. He cautions, however, that if both of the companies are small, cash flow problems may occur. By contrast, if a small company forms a joint venture with a larger company ("elephant and ant" scenario), the risk of culture clash is far greater. This clash is most commonly caused by the glacial speed which characterizes the decision making process of larger organizations and the comparatively spartan conditions of the smaller company.

A summary of the criteria to consider for a partner is listed in Table 5.

TABLE 5: Criteria to consider when looking for a joint venture partner

(1) Think through your own assets and liabilitics so as to be able to articulate the requirements of a co-venture.

(2) Does the potential partner have established marketing/distribution system in the market to be served?

(3) Does the potential partner have a sales force of reasonable size and image to call on your specific customers?

(4) Does the technology improve or complement your own?

(5) Can they supply of personnel required

- Managerial

- Technical

- Manufacturing/Production

(6) Does the potential partner have access to capital and "staying power"?

\section{What process is involved with forming joint ventures?}

In the process of negotiating a joint venture agreement the most crucial things to which one should attend include:

- Technical and/or commercial contributions from each partner,

- Initial and continuing financial contributions

- Key personnel desired

- Growth and profit objectives 
- Cost accounting

- Pricing

- Profit and loss distribution

- Types of decisions requiring board approval

- Measurement of venture's accomplishment and review of key personnel's performance.

\section{What are some of the current trends?}

According to the US Federal Trade Commission 2,287 new joint ventures were formed, between 1964 and 1975, in the US. Today most of the Fortune 500 companies are involved with joint ventures. This is a continuing trend. However, there is a shift towards more marketing strategic alliances in preference to joint ventures.

\section{R \& D LIMITED PARTNERSHIPS}

\section{Important Note}

In the early 80's it looked as if R \& D Limited Partnerships were going to become a viable source of investment capital for funding high potential projects with long $R \& D$ periods. This rosy projection stemmed from a 1974 interpretation of the Internal Revenue Code by which limited partners were not taxed on their investment, as long as they were taking a significant business risk. However, the 1986 modification of the tax laws, as well as the failure of many R \& D Limited Partnerships to be profitable, has limited the viability of $R$ \& $D$ Limited Partnerships. As a limited number of $R$ \& D Limited Partnerships are still being formed, their characteristics will be described. However, this type of funding should be considered as a very remote possibility.

\section{Definition}

An R \& D Limited Partnership is a way to raise capital to support R \& D that provides some tax benefits to the investors. Two types of partners are involved with this kind of arrangement referred to as General Partners and Limited Partners. The general partners are members of the company seeking funds (referred to as the sponsoring company). They provide the management. By contrast, the Limited Partners are individual investors who do not actively participate in the management, but who provide capital and share in the business risk. A tax benefit accrues to the Limited Partners (Deloitte, Haskins, and Sells, 1984).

In R \& D Limited Partnerships, the limited partners share in the anticipated benefits that will accrue to the sponsoring company. In fact, the Limited Partnership owns the technology. However, the sponsoring company can exercise an option to buy-out these rights through a royalty, equity, or joint venture arrangement.

Royalty Partnership: This is a buy-out option exercised by the sponsoring company. The limited partners receive a royalty rate of $6-10 \%$ of gross sales in exchange for providing the sponsoring company with one of the following options: (a) purchase the technology, (b) buy-out the limited partners, or (c) obtain an exclusive license to use and market the technology and spin-off products. Other forms of payment are possible including lumpsum payment in cash, stock or a combination of both.

Equity Partnership: In this situation,the sponsoring company and the limited partners decide to form a new corporation after the technology is developed, to market it and related products. The limited partners obtain considerable equity in the new corporation. 


\section{When should $R$ \& $D$ limited partnerships be considered?}

Given the changes in the tax law this option is probably not viable for most SBIR companies. In a conversation with Paine Webber it was recommended that technology companies consider angel and venture capital money before they consider an R \& D Limited Partnership.

\section{With whom should you form an $R \& D$ limited partnership?}

Given the limited number of R \& D Limited Partnerships that are being formed, if you wish to consider this type of funding, it is best to contact a large brokerage firm such as Paine Webber .

\section{What process is involved with forming $R$ \& $D$ limited partnerships?}

Numerous agreements are involved with $R \&$ D Limited Partnerships to assure that both parties are adequately protected and receive the maximum tax benefits allowed. These agreements include:

(a) Limited Partnership Agreement

(b) Base Technology Transfer Agreement

(c) Research and Development Contract

(d) Developed Technology and Partnership Purchase Options

(e) Developed Technology License Agreement

Other essential documents include:

(a) $R \& D$ Budget: A clear understanding of the costs and milestones is necessary in order to minimize tax and logistics problems resulting from unexpected expenses. This budget is part of the R \& D contract.

(b) Project Feasibility Study: These are independently prepared reports that allow the potential investor to assess the technical feasibility, as well as the commercial viability of the technology.

(c) Opinion of Patent Counsel: The patentability of the technology and when it is "reduced to practice" are important considerations, especially with royalty partnerships where long-term capital gains are achievable.

(d) Securities Option: This document is prepared by an attomey and indicates that the partnership units will comply with federal and state securities laws.

(e) Tax Opinion: This is prepared by a CPA or tax counsel and is intended to assure the potential investor that he will be able to realize the anticipated tax benefits.

(f) Selling Document: The "selling document" or "prospectus" is prepared if you intend to make a private placement. It should contain sufficient information to allow investors to assess the risks and merits of your offering.

Example: In 1982 Genentech, Inc., used a limited partnership arrangement to raise $\$ 55,000,000$. Six months later they raised another $\$ 32,000,000$ through a second partnership. 


\section{SUMMARY AND CONCLUSIONS}

Those of you who have been in business for several years know how tenuous financing can bel "Deals" that once looked sure don't materialize; sell cycles take much longer than expected; contracts are lost due to government cutbacks; clients fail to pay on a timely basis. Without the finances desperately needed to fuel your engine, the opportunity for successful commercialization becomes remote. The purpose of this chapter has been to present you with a look at alternative arrangemonts for obtaining funds: joint venture, R\&D partnerships, licensing, and strategic alliances. Each of these arrangements should be considered as options in the development of your financial strategy for commercialization.

Some of these financing arrangements may be new to you. You have probably been highly successful in obtaining $\mathrm{R} \& \mathrm{D}$ funds through writing grants. Obtaining funds from business investors may be a foreign arena for you. You will feel more comfortable when you have "played in the field" for awhile. (Given that many technologies have a long development cycle, you will need to continue grant writing to seek R \& D funds.) However, as you move downstream with your technology development plan you should begin to pepper your financial strategy with some of the other financing arrangements outlined in this chapter.

Many considerations should be made in the development of your strategy :

(a) your vision for your company;

(b) how much control you are willing to relinquish;

(c) the readiness of the market for the technology, and

(d) the best types of financing given your stage of development.

Table 6 shows the likelihood of various financing arrangements, given the development timeline for your technology. 
TABLE 6: Financing Arrangements as a function of development

\begin{tabular}{|c|c|c|c|c|}
\hline Stage & $R \& D$ & & & \\
\hline \multirow[t]{2}{*}{$\begin{array}{c}\text { Company Goal: } \\
\text { R\&D firm }\end{array}$} & $\begin{array}{l}\text { - SBIR } \\
\text { - own money } \\
\text { - angels } \\
\text { - alliances } \\
\text { - other contract } \\
\text { work } \\
\text { - licensing }\end{array}$ & & & \\
\hline & R\&D & Start-up & $\begin{array}{c}\text { Full scale } \\
\text { Manufacture }\end{array}$ & $\begin{array}{c}\text { Profitable \& } \\
\text { Expanding }\end{array}$ \\
\hline $\begin{array}{c}\text { Company Goal: } \\
\text { Manufacturing } \\
\text { and Marketing } \\
\text { firm }\end{array}$ & $\begin{array}{l}\text { - SBIR } \\
\text { - own money } \\
\text { - angels } \\
\text { - alliances }\end{array}$ & $\begin{array}{l}\text { - VC } \\
\text { - alliances }\end{array}$ & $\begin{array}{l}\text { - VC } \\
\text { - alliances }\end{array}$ & $\begin{array}{l}\text { - VC } \\
\text { - R\&D limited } \\
\text { partner } \\
\text { - IPO }\end{array}$ \\
\hline
\end{tabular}




\section{CHAPTER 3: BUSINESS PLANNING}

"Business planning" is typically approached as a necessary evil, as a "tickel" reculred to play the capitalization game. However, a more appropriate way to view business planing is as "theory construction" or "model building." At the outset, a scientist's view of his or" her business contains numerous assumptions and hypotheses. Through the application of" a systematic process these assumptions must be tested and discarded as deemed fit. Important variables must be isolated, and the discovery of lawful relationshlps among them must proceed rigorously. Just as a good scientific theory is fertile and guides scientific inquiry, a good business plan will focus your resources and guide the manner in which you develop your business. "Theories are nets that we weave to capture reality (Popper)." So it is with business planning. The business plan is the business counterpart to scientific theory and embodies the scientist's understanding of the business world in which the technology exists and can develop.

Business planning is often a painful process. To be successful it requires that the theory builder be willing to part with a perspective that he or she may hold that upon examination may not coincide with the evidence at hand. In most cases, the outcome of good, strategic business planning requires a change ... a modification in the technology, the product, the team, the direction, or the assessment of the opportunity.

Just as a scientist strives to observe, explain, predict, and control the phenomenon of interest, he or she must do the same in the business planning process. The scientist as business planner must observe the world in which the potential business opportunity exists. The most important variables to which he must attend are customers, competitors, market size, financial resources, risks, human resources and technology/product. He must gather sufficient information to explain the behavior of those variables so that adequate predictions can be made about their probable interaction. Strategies then need to be developed to maximize the likelihood that the course of development can be controlled in the desired fashion - that is, the creation of a commercially viable business. Somewhat different approaches will be required than the methods to which you are accustomed, since in business you are dealing with a dynamic system which is freculently difficult to control.

The scientist should expect the business planning process to require about as much time and effort as conducting a masters thesis. This process, however, needs to be entered into by a team. As a team will execute the plan, it is important that a team be involved with its development, and take "ownership." Now is the time to begin coalition building, a skill that you will need throughout the business development process. As the driver of this process, you will be required to learn about the variables of importance: customers, competitors, market size, financial resources, risks, and human resources. Although you will not be expected to become an expert in all of these areas, you must understand them so that you can be effective in coalition building and in modifying your perspective, as appropriate. The most successful scientist/entreprencurs are those who continue to learn and develop in new directions.

\section{INTERNAL VALUE OF A BUSINESS PLAN}

Most small companies run lean. They operate on the "Grizzly Principle" -- that is, if you stop running, the grizaly bear will get you. You have to keep moving forward in order to survive. The business landscape is dotted with safe havens where you can stop momentarily (large contracts) - before you quickly move on. In this grizzly, entrepreneurial environment, it is common that people fail to communicate adequately. Everyone is running, more or less in the same direction. As new people join the organization, they 
must Jump in and learn to run alongside the othors fairly quickly. The direction in which people are running is not necessarily correct. In the absence of sound, strategle planning the direction in which people are running may prove to be apocalyptic.

A sound, strategie business plan not only draws together the efforts of this team, but assures that everyone is moving downfield together in the best possible direction. The value of the business plan as an internal document is that it can:

(a) provide the mission for the staff, educating them regarding the company's past, present, and future goals,

(b) identify strengths, weaknesses, opportunities, threals, and trends,

(c) communicate expectations and priorities,

(d) provide the basis for measuring performance against specific milestones, as well as

(c) provide a framework tor making intelligent management decisions.

\section{EXTERNAL DOCUMENT}

External to the company, the primary purpose of a business plan is to represent the business opportunity to potential investors. As indicated in Chapter 2, potential investors are molivated by the potential relum on investment. The whole purpose of the business plan is 10 demonstrate the likelihood that they will realize an acceptable, reasonable return if they invest in your company. Your plan must thoroughly address the variables that are known to be correlated with business success. Highest among these are market considerations - remember Silver's DEJ's. In fact, the most frequently cited reasons for failure in the marketplace are inadequate market analysis (45\%) and lack of marketing/ sales effort (25\%) (Hopkins and Bailey, 1971).

There are many ways to draft a business plan. The business plan outline that we will follow is listed on the following pages. The purpose of presenting the outline at this point is to familiarize you with the nature of the product you will be creating during the next 16 weeks. Keep in mind that the business plan itself is solely the reflection of the strategic thinking which has preceded it. In Section II attention will be given to project planning, to assure that you devote sufficient time to the plan. In Section III efforts will quickly shift to a process for surfacing the variables of significance to your business opportunity and developing a strategy for realizing your business potential. Each of the elements presented in the outline will be discussed in delail in Part II of the workbook, with examples provided. 


\section{OUTLINE OF BUSINESS PLAN}

I. Executive Summary

II. Mission Statement

III. Products/Service

IV. Murkat

V. Competitor's

VI, Environment

VII. Goals

VIII.Objectives

IX. Constraints

$X$. Strategles

XI. Programs

XII, Management

XIII. Resources

XIV. Contingencles

$X V$. Projected Income Statement

\section{Description of Each Section}

\section{Executive Summary}

This section should be no more than 2 pages in length and should highlight the nature of your product/technology; the market in which this fits; your sustainable competitive advantage; your management team; projected financial data for 5 years; the type of financial arrangement that you are sceking (licensing, $R$ \& D partnership, venture capital, sale, other), as well as a statement describing the potential return to the investor.

\section{Mission Statement}

This is no more than one paragraph in length and clearly answers the following questions:
a. Who are we?
b. What business are we in?
c. For whom do we do it? and
d. Why do we do it?

\section{Product/Technology}

In this section you should describe your technology or product. As much as possible, write this in such a way that the feature, advantages, and benefits of your product or technology are crystal clear. Technology or product milestones need to be clearly defined.

\section{Market}

This section should contain information about the market which you have determined represents the best opportunity for your technology/product. Types of issues which should be addressed in this section include questions such as:

a. What is the target market?

b. What is the size of the market (total and served available)? 
c. How do you segment that market?

d. Who are the competitors? What \% of the market do they have?

c. Describe the customers, their preferences for product/services, and their reasons for purchasing.

\section{Competitors}

In this section you should demonstrate a thorough understanding of the competilors in your Identilled market segment. Even if' you are only Interested in licensing your technology or forming some sort of teaming arrangement, you must develop this sectlon. You will find that you cannot adequatcly represent the opportunity to an investor or select the best flnancing arrangemont l'or vourself If you have not considered these issues.

\section{Environment}

This section should identify the key environmental assumptions that you are making regarding federal, state, and local policies, interest rates, inflation, and technology changes which underline your plan. This section should include a summary of the opportunities and threats in the specified market.

\section{VII, Goals}

In this context, goals are meant to be long term (3-5 years) rather than short term (1-2 years). They need to address the questions:

a. What do we want to become?

b. Where do we want to go?

If your goal is to take certain types of technologles to a certain point in development and then license them or develop R \& D partnerships, this is the section in which this should be clarified.

\section{VIII, Objectives}

This section needs to contain a roadmap which concisely states measurable targets that you intend to meet in pursuit of the goals outlined in the preceding section. Goals are relatively broad statements which tell you "which way," while objectlves answer the question "how much, by when?"

(Short-term $1-2$ years).

\section{Constraints}

What types of limitations is the organization working under which affect the development and implementation of the strategic plan, both externally and internally.

\section{$X$. Strategies and Tactics}

This section describes the set of actions which the company has planned near term (1 to 12 months) in order to move towards its objectives, while achieving its goals along the way (in a manner which is mindful of the constraints).

\section{Programs}

In this section the programs need to be identified which are critical to the pursuit of the strategies in each functional area: Finance, R\&D. Manufacturing, Marketing \& Sales. 


\section{Management}

Hore the managenfent team is described in such a way as 10 engender conlidence willih the potential investor.

\section{Resources}

This is a "bottoms-up" analysts of all the major resoureses whose avallability is sillical to

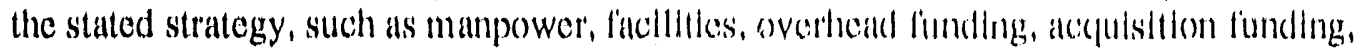
travel, equipment, etc. Indicate the specilte sources and plans for obtalning these recultements as noeded.

\section{Contingency Planning}

One must articulate the key assumplions that are belng made and then put a contingency plan in place for each assumption for which ellher the conlidenee liactor ts low or the potential impact on their strategy is high. 'Typleal lypes of assumptions which should be questioned Include: stability of management team, and quality and continuity of suppll-. crs. Plan for what you would do "lf ..."

\section{Progiected Income Statement}

This section should contain a projected income (Prolit and Loss') statement if your intent is to manufacture yourself or to involve another company in some sort of teaming al'rangement. Other infomation that is important to consider in this sectlon is how unencumbered a deal this would be for an investor.

The entire plan should be no more than 3010 40 pages in Jength, Including the summary tables and pro formas. What we typleally find is that we tend to generate much more material than is required for an external ullization ol the platl. However, thls expanded version becomes an operating plan which is highly useful for intemal consumption,

\section{SUMMARY AND CONCLUSIONS}

Business planning is a very rewarding experience when approached ats an opportunity to gain control over one's future. The process for developing a business plan is very similar to the approach taken by scientists in theory and moded development. Basic assumptions and hypotheses are put forth and then tesied via the applleation of specilic procedures, In sctence, as well as in business planning, "conjecture is gradually replaced with certilude."

The business plan itself is merely a document which summarlass your rescarch findings and also Includes your strategles for future growth. 'The processs of developing the plan is more important than the plan itself. Your growth ats all entrepreneur is the result of the process, not the product. The outline for the business plan contained herein is merely an advanced organizer. It gives you an idea of what you will be able to produce after going through the process. More detalls on writing the plan are presented in Chapter 9. However, as the process is important, please continue to Chapter 4, which describes how to integrate the business planning process into your schedule. 


\section{CHAPTER 4: THE DAWNBREAKER BUSINESS PLANNING PROCESS}

During the next 16 weeks we will assist you in developing or revising your business plan. Sixteen weeks is sufflcient time to develop a good plan, if you make this process a priority, Belore you make the commitment to begin, you must decldo how to add this activity to your already hectic schedule. The purpose of this chapter is to suggest ways in which this can be accomplished. In order to complete the process on time, you will need to:

- have a clear understanding of what is involved.

- be committed to completing this process,

- make it clear to your staff that it is a priority;

- clarify who will be involved;

- and develop a milestone chart.

To make it easier for you to understand the process that we will use, some of the key items that need to be addressed when beginning a new project are outlined in Figure 9.

Figure 9: Flow"Chart of items to clarify when beginning a new project

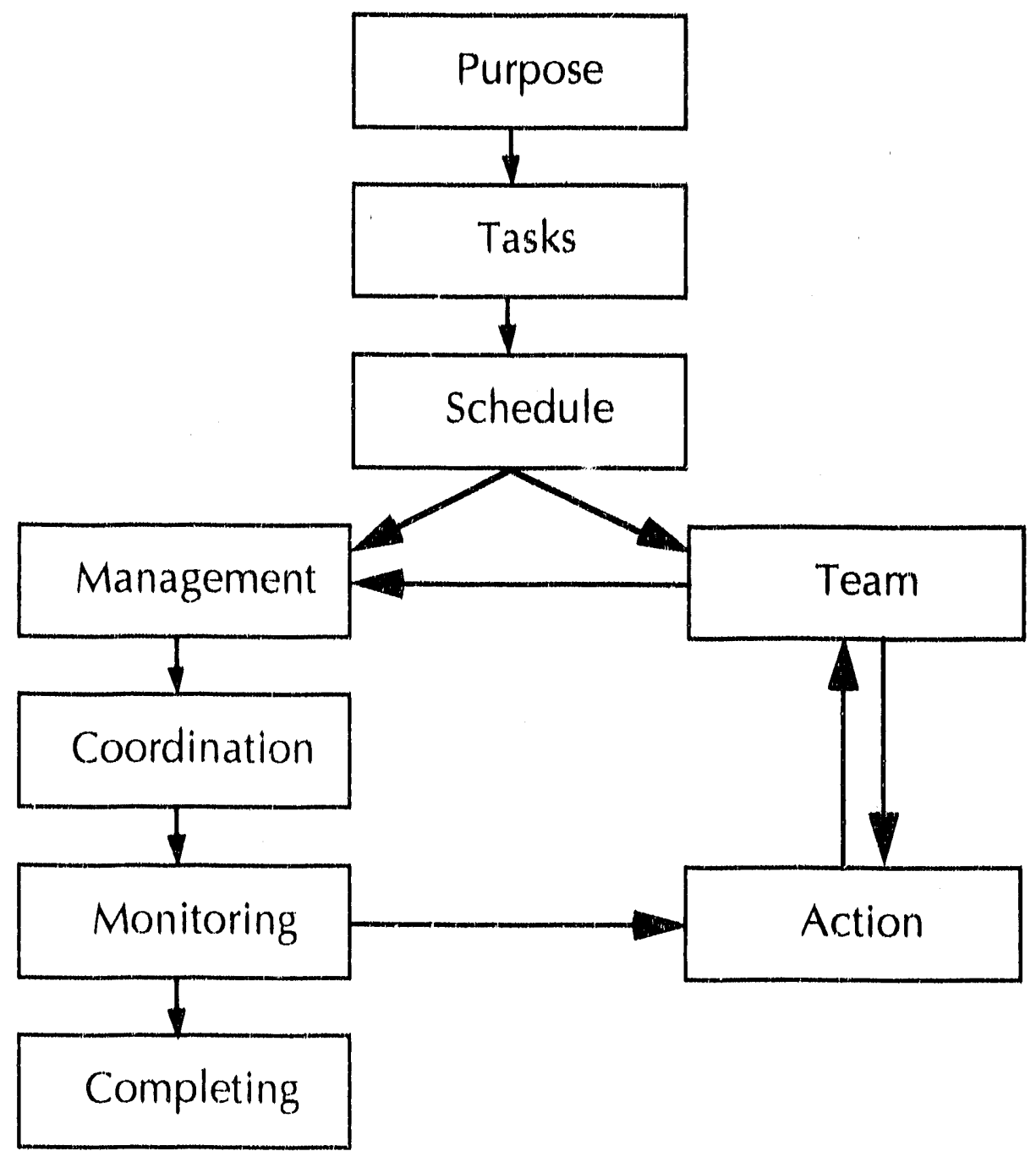




\section{PURPOSE OF THIS PROJECT}

The purpose of this project is to develop a high quality business plan within 16 weeks.

All of you who complete the process will have a different perspective on your business when you findsh and will have a business plan in hand that can be used to approach private investment. sources.

\section{TASKS}

As indleated In the Preface, there are many books which indicate the types of questions that should be addressed in a business plan. However, the problem is not in knowing the questions 10 be asked, but in developing good, sound answers, In this age of Information, much diala is avatlable. However, the problem is in knowing where to look for the informallon and how lo determine if you have answered the important questions adecuately.

Section III, the Workbook, has been organized around questions, In each chapter questhons of increasing complexity are presented. The tasks to be completed in this phase of the Commerciallzation Project are to seck answers to the questions presented in Chapters 6 through 8 and complle them as Interim reports. Each questlon has at least a single page dedicated to it with the following subheadings:

- Why is this question important?

- Where should you look for answers (Background and Activities)?

- How will you know il the questions have been answered adequately? (Process \& Results)

To provide you with an overview, you will find a listing of all the questions to be answered, grouped according to major variables; customers, competitors, market size, linancial resources, environment, human resources, and technology /product. How you organize the interim reports and compile the information that you gather is up (0) you. There are two commonly used approaches which you might lind useful:

(1) Organize by variable: Collect materials in a threc-ring binder with dividers for each variable: customers, competitors, market size, financtal resources, environment, human resources, and technology/product.

(2) Organize by sections of the business plan: Conversely, you could also organize materials in a three ring binder, with dividers for each section of the final business plan.

To assist you in organizing, cach question will bear an indication of the variable or business plan section 10 which the question pertains. 


\section{QUESTIONS TO BE ANSWERFD IN CHAPTERS 6.8}

\section{Company}

Who are you? What business are you in?

What is your' mission'?

What is your sustainable competllive advantage?

What would the cost of entry be l'or a competitor to enter this market'?

\section{Technology/product}

What is your technology/product?

What are the possible applicatlons of your lechnology?

Who would benefit from these applications?

Who would be affected by these applications?

What is the SIC (Standard Industrial Code) associated with this technology or product?

Feature/Advantage/Benclit Analysis of Technology/Product

What are the proprictary features of the technology/product

How important is the intellectual property position to the success of the business'?

\section{Market}

Who is the customer? Who is the end user?

What industry are the customers drawn from?

How is the market segmented?"

What will the technology/product do lor its user?

What need does the technology/product fill'? Is this need real, created, or imagined?

What is the growth rate of this market?

What is the size of the market (domestic and international)?

What are the trade journals for this market?

What are the major conferences?

What is the annual growth rate of that industry?

\section{Sales}

What is your company's sales history for your technology/product?

How are buying decisions made?

Who makes the decistons?

How long does it take for such decisions to be made?

What affects their buying decision?

\section{Distribution}

What distribution channels do your competitors use?

How does the distributor's compensation on company products compare with its compensation on other products it distributes?

What other products does each distributor sell?

\section{Competitors}

Who are the competitors in this market?

Who else is expected to enter this market?

What are the characteristics of these competitors at present?

How do these competitors compare on the following items: R \& D capability, marketing capability, management, financial resources, product FABs, market share?

What was this market like 10 years ago, 5 years ago, 1 year ago?

What are the future projections for such products/technologies between now and the turn of the century? 


\section{Environment}

Is there any legislation (State or Federal) or any policies which will affect this market place during the next 10 years?

How will the following affect the industry:

- interest rate

- demographics

- general economic trends

- What regulatory agencies have an impact on this industry?

\section{$R \& D$}

How does a company select the applications they develop?

What type of market data are collected before proceeding with R \& D?

What customer specifications become part of R \& D plans?

What is the development timeline for the technology/product with critical milestones indicated?

\section{Manufacturing}

What kind of manufacturing does the company perform?

What are the major operations and their sequence.

What are the key segments of the manufacturing process?

\section{Financial}

What sources of funding does your organization presently have?

Do you have any existing agreements that would have a negative impact on your future funding or dusiness relationships?

How clear cut a deal would this be for an investor?

What are your financial requirements?

\section{Management team}

What kind of incentives are in place for management?

What is the track record of the management team, individually and together?

How are roles and responsibilities clarified and coordinated?

\section{Strategies}

What are the company's $R \& D$, marketing, and financial strategies?

This list contains all the questions that you will be asked to address in the process of developing your business plan. For a real "eye opener," we refer you to a book by David Gladstone, entitled Venture Capital Investing: The Complete Handbook for Investing in Small Private Businesses for Qutstanding Profits. Gladstone includes almost 100 pages of questions that he recommends venture capital firms consider when making investment decisions. 


\section{SCHEDULING YOUR TIME}

You will receive the greatest benefit from this business planning process if you allow yourself adequate time to go through the entire process, i.e. time scheduled during each of 16 weeks. You should assume that 300 man-hours are required to develop a good plan. At least half of that time is spent in data gathering, number crunching, and writing the actual plan, activities which could be accomplished by others.

\section{MANAGEMENT}

You will need a project leader to coordinate and monitor the business plan development process. This person should be well organized and comfortable in this project management role. His or her role should be made clear to all the members of the team.

\section{TEAM}

We have assisted numerous companies with business plan development, becoming a part of their team for short periods of time and assisting them with the planning process. Based on that experience, the following recommendations are made regarding how to leverage your time.

The process of developing a business plan involves various cognitive skills including:

- data gathering

- review

- decision making

- re-evaluation

- number crunching

- strategizing, and

- writing

Review, decision-making, re-evaluation, and strategizing are higher level skills and need to be accomplished by the management team. However, other tasks such as data gathering, number crunching, and drafting the final plan can be done by others, acting under the guidance of the management team. Considerable time can be saved in the business planning process by finding others to assist with these activities.

However, let me emphatically stress that the management team must make the decisions, develop the strategies, re-evaluate the implications of new data and manage the team. There is no one better equipped to perform these activities than the management team, as the team knows your product and vision better than anyone else.

Some of you may be in a position to hire additional assistance, others may need to seek free assistance, or do all of the activities yourself. Listed below are various options that will help you leverage your time. When exploring these options be sure to assess if the individuals you plan to involve can provide you with the information that is needed, in the required form in a very short period of time. These resources should be used for data gathering, number crunching and writing only. Again, the decisions, the reevaluations, and the strategies must be yours. 


\section{ADDITIONAL RESOURCES TO ASSIST IN DATA GATHERING}

$S B D C$ programs: The Small Business Development Center (SBDC) program is federally mandated and administered by the States. Across the nation, many universities and community colleges have SBDC's afliliated with them. The Small Business Development Centers provide free assistance to small businesses. I have found that the skill levels of the staff vary tremendously. However, there are many outstanding Centers that provide excellent assistance with collecting secondary market research, cash flow analyses, and the like. To find out if there is an SBDC near you contact your local Chamber of Commerce or State Department of Economic Development. For the most part, they are not accustomed to working with high tech lims.

SCORE: This program is run by the SBA and consists of retired executives who are willing to provide free assistance to companies. You can obtain a list of SCORE members and their area of expertise by contacting a local chapter in your community.

Graduate students: There are many top-notch senior or graduate students who you could employ on an hourly basis to gather some data for you. Contact the Deans of the Business Schools in your neighboring universities to find out who they would recommend, as well as the typical hourly rate. Graduate students in finance can also be hired to assist with the number crunching.

Consultants: Depending on your financial situation, you may be able to hire a consultant to work with you who will assist in data collection.

No matter which sources you use, be sure to make explicit the type of information you need, by when, and in what format.

The casicst way to keep track of who is involved with the various aspects of the business plan development might be to organize work to be done in preparation for each interim.

\section{SUMMARY}

Business planning is time intensive. It is therefore important that you begin by giving consideration to project planning. These considerations must be made within 1 week of the Kick-Off meeting, as interim reports will become due fairly quickly.

The process oullined in the workbook is one which is iterative in nature. From the outset, you will be asked to give altention to the variables of primary importance : customers, competitors, market size, environment, costs, management, and technology/product. In subsequent chapters more refined data will be sought in each category and your focus will shift from data gathering to strategizing, decision making, re-evaluation and numbercrunching. It is recommended that you scan the workbook and engage some people to begin working on gathering the data required for Interim Reports 3 and 4, while you are working on Reports 1 and 2. 
TABLE 7: Cognitive skills required in preparation of each interim report

\begin{tabular}{|c|c|c|c|c|c|}
\hline $\begin{array}{c}\text { Cognitive } \\
\text { Skills }\end{array}$ & $\begin{array}{c}\text { Mind } \\
\text { Map }\end{array}$ & Report 2 & Report 3 & Report 4 & $\begin{array}{c}\text { Business } \\
\text { Plan }\end{array}$ \\
\hline data gathering & $x$ & $x$ & & \\
\hline $\begin{array}{c}\text { number } \\
\text { crunching }\end{array}$ & $x$ & $x$ & $x$ & $x$ \\
\hline $\begin{array}{c}\text { business plan } \\
\text { writing }\end{array}$ & $x$ & $x$ & $x$ & $x$ & $x$ \\
\hline review & $x$ & $x$ & & $x$ & $x$ \\
\hline decision making & $x$ & $x$ & $x$ & $x$ & $x$ \\
\hline strategizing & $x$ & & $x$ & $x$ \\
\hline re-evaluation & $x$ & & & $x$ & \\
\hline
\end{tabular}




\section{CHAPTER 5: BENCHMARK YOUR STARTING POINT}

"You read a book from the beginning to the end. You run a business in the opposite way. You start with the end, and then do everything you must to reach it."

-Harold Geneen

Cited in Thomsett, M., 1990

As the business plan represents your overall strategy for developing your business, there are certain things that you must consider when beginning this process:

(1) where are you on the technology/product development line,

(2) what types of funding arrangements are presently most viable given your stage of development, i.e.

- strategic alliance

- venture capital

- R \& D partnerships

- initial public offerings, and

(3) what type of business do you wish to develop?

- R \& D firm

- manufacturing firm

- marketing firm

The purpose of this chapter is to provide you with information and tools that will help you reflect upon these issues.

Where are you on the technology/product development cycle?

Technological innovations vary between being evolutionary and revolutionary in nature (See Figure 10)

FIGURE 10: Different Types of Innovation

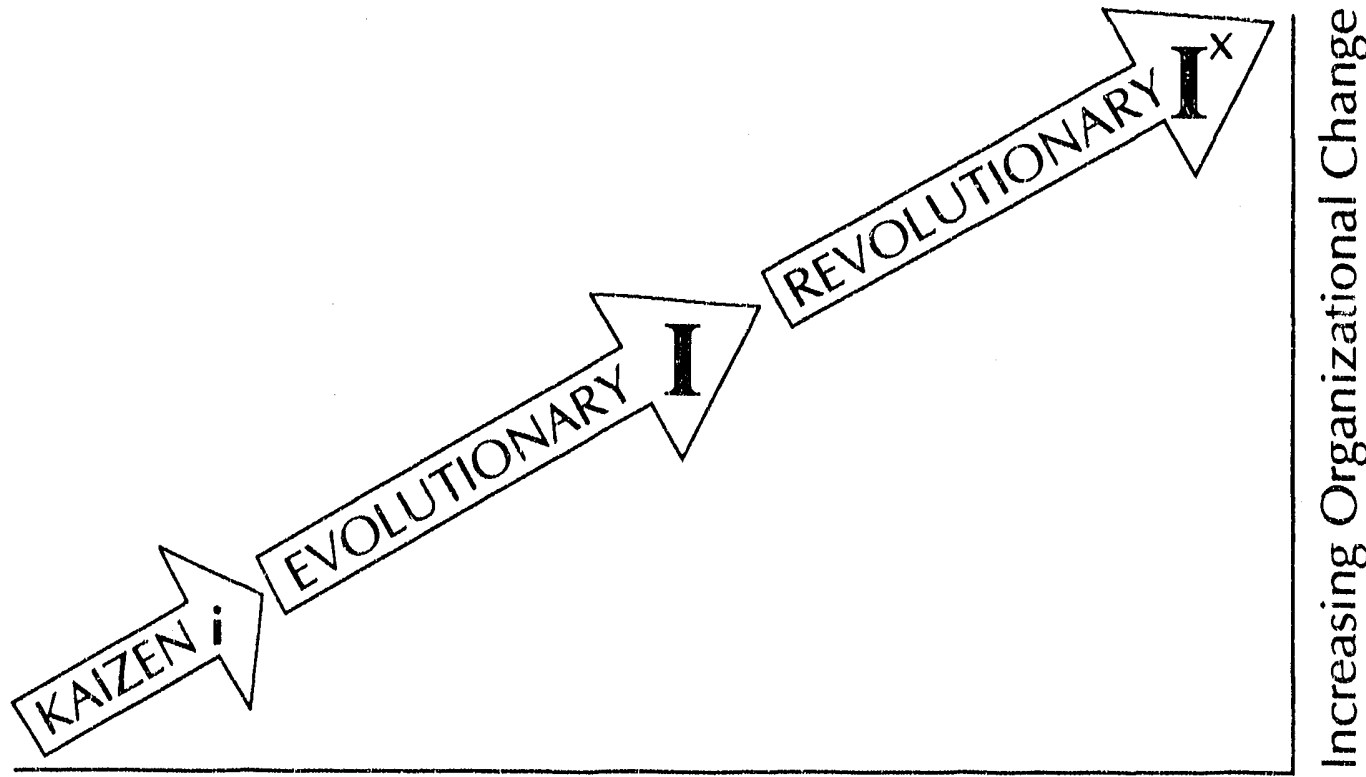

Increasing Departure from Conventional Thinking 
Evolutionary innovations are those which represent extensions of existing products and/ or processes already in use in the commercial arena. As seen in Figure 15, cvolutionary innovations require a moderate degree of organizational and/or societal change, and a moderate degree of departure from conventional thinking. By comparison revolutionary innovations represent a quantum leap and a clear break with the prevailing paradigms. The first telephone, the first vaccine, the first genetically engineered human genes, all represented revolutionary innovations; they were also hou! A potential champion, sponsor, or customer was looking for that breakthrough whether that person was an individual like Hubbard (champion); a country (customer); or a discipline (medicine, the sponsor).

Those of you who are pursuing revolutionary innovations will require the greatest degrec of organizational and societal change. From the investor 's perspective you represent the greatest risk and perhaps the greatest opportunity for gain. The "big P" investors described in chapter 2, as well as the R \& D Limited Partnerships which invested in Genentech, clearly looked to invest in potentially revolutionary innovations for which the market was waiting!

$\mathrm{Be}$ aware that the development path for your company will vary depending upon whether your company is built around an evolutionary or revolutionary technology and/or product. The funding options that are available to you at various points in the development process will also vary. For cxample, if you are working on a revolutionary innovation for which there is a large, proven market and anxious investors, you are in a better position to try and negotiate large sums of money from R \& D Limited Partnerships, Venture Capitalists, and corporations during the long $R \& D$ cycle. However, if there is not a large, proven market waiting for the technology (most often the case) and if you still have a long development cycle, it is unlikely that you will be able to obtain large investment capital from these sources during the development stages. You will need to rely on SBIR funds, federal customers, strategic alliances, "angel" monies, and initial public offerings.

\section{What do you enjoy the most?}

Apart from assessing the type of technology or product you are developing from a risk perspective, other important considerations are your desires and wishes for the company. In the final analysis, the strengths and weaknesses of any company are nothing more than a reflection of the person in charge. It therefore, behooves you to take stock of your own strengths and weaknesses, your leadership style, and your goals. This is one of the most difficult tasks: for anyone. However, in anticipation of a growth pattern you select for your company, these are important considerations. Based on your analysis, you should consider whether you wish to develop your company in one of the following ways:

Remain a technology development firm. Taking this path implies that the founder's delight comes from conducting research. It is likely that the company's staff will remain fairly small and homogeneous (mostly scientists) and develop as a sole proprictorship or partnership. For the most part, venture capital is not a viable option for R \& D companies. Venture Capitalists want 10 invest in companies whose primary motivation is to make money - - that is, after all the only way they realize a return on their investment.

The following funding options are the most likely for an R \& D firm:

Option 1: Fund your R \& D through a combination of SBIR contracts, as well as contracts with federal and/or commercial clients. Patent positions should be protected and technology licensed to others as it becomes available. In time the royalty stream would supplement the company coffers. However, it will lake awhile for the royalty stream to grow, sinec royalty payments are normally predicated on net sales. 
Option 2: If your technology is revolutionary in nature and addresses a pressing social need, $R$ \& D could also be funded through $R$ \& D strategic alliances.

Become a mamufacturing company. Taking this path implies that in addition to $R \& D$, the opportunity to develop a market and to realize significant financial return is important to the founder(s). In order to succeed, this company will have to become differentlated with a strongly defined marketing and sales function, to complement the R \& D and manufacturing. You should anticipate that you will need to develop a strong management team; share control; and potentially assume a role other than CEO at some point in the company's evolution. Whether or not another role is appropriate depends on the scientist's ability to develop as a businessman or businesswoman. The following funding options are those commonly available to such firms.

Option 1: You should entertain the full range of options, carefully strategizing which types of funding are most appropriate for different stages of development (i.c. angel money, venture capital, joint venture, strategic alliance). Each financial arrangement that you make would have to be made in light of other options which you wish to have open to you at a later point in time. SEC considerations will be important to consider, as most of these options require compliance with SEC regulations.

Option 2: You may form a strategic alliance with another company, using the marketing prowess of the other firm to complement the enginecring/manufacturing strengths of your own.

\section{Five years from now? \\ "If you don't know where you are going, you will probably end up somewhere else."}

- Laurence J. Peter

Cited in Thomsett, M., 1990

In considering how to enhance the company's growth, it is important to develop a formal/ written vision statement. Usually a five-year outlook is good. Your vision is your dream! It is a statement of what you will ideally look like when you grow up. Guidance on developing your vision will be provided in Chapter 6 .

\section{SUMMARY: BENCHMARKING YOUR MINDMAP}

As mentioned in Chapter 4 every entrepreneur that we know has a "plan," even if it is not articulated on paper. This "plan, mind map, or operating theory" guides the entrepreneur's behavior. However, most often this plan is based on conjecture, rather than on data collected in a rigorous fashion. The overall purpose of this business planning process is to substantiate, modify, or refute the "mind map." To benchmark your starting point, the first task is to write down your "mind map" 
At this time, the format in which you represent this information is totally unimportant, In providing the answers, you should not research these issues. Merely benchmark your starting point, by providing answers to each of the questions on the following pages. This Interim Report is meant to be an honest reflection of the information which is presently guiding your behavior. Do not be embarrassed if you have no answers or incomplete answers. That is expected; that's why we will step you through the process described in Chapters 6 through 8. As we go through the business planning process, you will be asked periodically to refer back to the mind map to see if the research you will conduct subsequently either supports, expands, or refules your mind map. 
INTERIM REPORT 1: "MIND MAP"

INSTRUCTIONS: Answer each of the following questions.

\section{Technology/Product}

(1) Is your company dealing primarlly with technology or product development?

(a) technology

(b) product

(2) How long do you anticipate it will take to finish development?

(3) Do you already have quallfied customers tor this technology/product?

(a) If Yes, list who they are and how you know that they are qualified buyers.

(4) Does your technology or product represent a total break with the past, or an extension and refinement of presently used products/processes?

(a) If a total break, please describe from what it is a break.

(b) If an extension or refinement, please indicate of what is this an extension or relinement?

(5) Does this technology or product represent a place of signilicance in the scientific community? Please explain

(6) What potential applications do you see for this technology/product?

(7) What other technologies represent a threat to this?

\section{Customers}

(8) Who are your current customers?

(9) Who do you see as potential customers? Please describe the extent to which you have interacted with the potential customers.

(10) How do present or how will future customers learn about your company?

(11) What needs does your technology or product lill?

(12) Who ale potential international customers?

\section{Competitors}

(13) What technologies are possible replacements for yours?

(14) What technologies will yours replace?

(15) What other companies are working on comparable technologies/products?

(16) Is your concept/product/technology patentable? Are you protecting your patent position?

\section{Market size}

(17) What market niche are you targeting with your technology/product?

(18) What is the size of the market?

\section{Financial resources}

(19) Until now how has the growth of your company been financed?

\section{Human resources}

(20) Are you a sole proprictor, or do you have a management team?

(21) If you have a team, please describe the other members of your team, their skill bases and the team position they play.

\section{Environmental analysis}

(22) What past, present, or future legislation on the Federal, State, or Local level has had or will have an effect on your technology/product?

(23) What general societal needs does your technology/product fultill? 


\section{CHAPTER 6: INTERIM REPORT 2}

\section{Tasks}

There are elght tasks associated with the preparatlon of Interim Reporl \#2, Each lask consists of enducting the research reculred to answer the questions listed in Table 8 . The format of the table is intended to assist you in project planning. Please use it to track who is responsible for the completion of each lask, the names of other people to be involved or kept informed, as well as the designated completion date for each lask.

TABLE 8: Project planning guide for Interim Report \#2

\begin{tabular}{|c|c|c|c|c|}
\hline Questions & Responsible & $\begin{array}{c}\text { Also } \\
\text { Involved }\end{array}$ & $\begin{array}{l}\text { Keep } \\
\text { Informed }\end{array}$ & $\begin{array}{l}\text { Completion } \\
\text { Date }\end{array}$ \\
\hline $\begin{array}{l}\text { What is your } \\
\text { tectholongy/product? }\end{array}$ & & & & \\
\hline $\begin{array}{l}\text { What aro possible } \\
\text { applicatlons? }\end{array}$ & & & & \\
\hline Who's the customer? & & & & \\
\hline $\begin{array}{l}\text { Who would benefil from } \\
\text { applications? }\end{array}$ & & & & \\
\hline $\begin{array}{l}\text { What is your silstainable } \\
\text { competilive advantage? }\end{array}$ & & & & \\
\hline What is your vision? & & & & \\
\hline $\begin{array}{l}\text { What is your companiy's } \\
\text { organizational struclure? }\end{array}$ & & & & \\
\hline
\end{tabular}

\section{Time}

You will need to allocate time to conduct the rescarch requited in order to answer each of these questions. The types of tasks Involved in completing Interim Report \#2 are data gathering, strategizing and decision making and will therefore involve your management team and some support staft. If the management team is only one person, we would encourage you to hold some ol these discussions with other people that you trust and respect, in order to gain another perspective. 
TABLE 9: Cognitive skills required in preparation of each interim report

\begin{tabular}{|c|c|c|c|c|c|}
\hline $\begin{array}{c}\text { Cognitive } \\
\text { Skills }\end{array}$ & $\begin{array}{c}\text { Mind } \\
\text { Map }\end{array}$ & Report 2 & Report 3 & Report 4 & $\begin{array}{c}\text { Business } \\
\text { Plan }\end{array}$ \\
\hline datal gathering & $x$ & $x$ & $x$ & $x$ & $x$ \\
\hline $\begin{array}{c}\text { number } \\
\text { crunching }\end{array}$ & $x$ & $x$ & $x$ & $x$ & $x$ \\
\hline $\begin{array}{c}\text { business plan } \\
\text { writing }\end{array}$ & $x$ & $x$ & & $x$ & $x$ \\
\hline review & $x$ & $x$ & & $x$ & $x$ \\
\hline decision making & $x$ & $x$ & $x$ & $x$ & $x$ \\
\hline strategizing & $x$ & & & $x$ \\
\hline re-evaluation & $x$ & & & $x$ & $x$ \\
\hline
\end{tabular}

\section{Report format}

In organizing the Interim Report, it is suggested that each question be addressed on a separate page(s). The top of the page should contain the following:

- the question

- the variable to which this question is related

- the name of the section of the business plan to which it is related

- the names of the people involved with gathering the intormalion

- the date

Each Interim Report should contain the research you have collected in response to each (juestion. As you proceed to the next page, you will notice that the chapter is organized around questions, with cach question becoming a task. The end of each task description has a section labeled Results. It is the compilation of the Results which becomes the Interim Reports that you send to Dawnbreaker. 


\section{WHAT IS YOUR TECHNOLOGY/PRODUCT?}

\section{Type of question}

Varlable: Technology/Product

Section of Plan: T'echnology

\section{Why is this important?}

In your business conversatlons, one of the most frecuently asked questions will be to doscribe your' technology or product. It is imperative that you have a clear', succinct statement describing your technology or product.

\section{Actlvitles' and background}

It is falrly easy to doscribe your tochnology or product to othor speciallsts in your ficld. However, the challenge is to simplity the doscription, so that you can express lis value to someone outside your field. Begin to describe your technology or product from the perspective of the neads it addresses.

\section{Have I answered this question adequately?}

Process: For the time being you will have answered this cuestion adecuately li you have gonerated a list that contains a clescription of at least five features of your lechnology or product and a equally long list of advantages.

Resists: Using the tuble provided below, list the features of your product or the characteristics of your technology, In the second column describe the advantages of that feature from the perspective of the end user.

TABLE 10: Features and advantages of technology/product

\begin{tabular}{|l|l|}
\hline Prodact Features & Advantages \\
\hline & \\
\hline & \\
\hline & \\
\hline & \\
\hline
\end{tabular}




\section{WHAT ARE POSSIBLE APPLICATIONS OF YOUR TECHNOLOGY?}

\section{Type of question}

Variable: Technology/Product

Section of Plan: Product/Technology

\section{Why is this important?}

In recent conversations with members of the Investment community, it was indiented that they would like to sec greater initial attention given to the expression of the possible range of applications for the technology. Although you must quackly focus, it is useful to spend some time in divergent thought, Re-examine the possible applications that could be made of your lochnology and which ones appear to have greater commerclal viabillty.

\section{Activitles' and background}

It is ofien difficult to imagine a use for a technology beyond that for which it was intended. This task is made especially difitcult not only because of "functional fixedness," but also because people tend to be specialists, rather than generalists. Let us share two suggestlons lor ways in which you could obtain additional insight into other applications.

\section{(I) Use of mainstream media}

In an April 1991 issue of Technology Access Report, Lawrence Livermore National Lab reported great success with two rouline press releases that they issued to coincide with a mecting of the Materlals Research Society, One release regarding "acrogels" was picked up by PBS and the New York Times. As a result over 400 commercial inquiries were received. In a slmilar lashion in August 1990 a press release regarding "cermets" was pleked up by KRON-TV near San Francisco and later by CNN. This likewise resulted in incuiries from various manufacturers who suggested altemative applications. One suggested application was for making golf club heads from cermet, a possibility which is now being explored in conjunction with a sporting goods marnufacturer. Popular televiston, radio, and written media can be useful as an indirect means of gathering ideas regarding applications. Popular media which provide broad exposure include:

- Wall Street Joumal

- Washington Post

- US News and World Report

- Business Week -Developments to Watch Section

- CNN

- Public Broadcasting Station

\section{(2) Focus group with divergent manufacturers:}

If you ask any specialist how a material or technology can be used, their answers will reflect their specialized experience. You need to create an opportunity to have people react to your technology who can look at it through different eyes. As the customers for many of your technologies and products will be manufacturers, one way to gain different perspectlves is to bring logether a group of individuals from manufacturing companies who represent totally diverse fields. After briefly describing what your technology or product can do you could ask them to indicate:

- What manufacturing or technology problems they frequently faced for which this might be a solution?

- 'To which technology, application, or product that they had used, is this most similar? 
Having a small, contained group would cnable you to ask particlpants to sign Non Disclosure agrecments, if that is appropriate.

As money is often an issue for small companies, one way to consider approaching such a task is to utllize mombers of SCORE. MOst SCORE organlzations have a list of their nember's areas of expertise, as well as previous organizational arfiliation. As members of SCORE provide their time for free, you could potentially obtain a group of highly skilled individuals who would be willing to partleipate in such an endeavor.

\section{(3) Brainstorming group with management team/staff}

If' you do not wish to bring this technology to anyone else's attention, another approach that you could take is to ask members of your staff to participate in a brainstorming session. In preparation, you could ask everyone who will be involved to find five trade joumals from very diverse disciplines. Ask them to spend a couple of hours scanning the journals, before holding the brainstoming session. The new stimulation from totally different sources, might also lead to the generation of new applications.

\section{Have I answered this question alequately?}

Process: There are many different constraints facing you: the proprictary nature of the technology, lack of time, previous commitment to a course of action, and the like. You will have answered this question adequately, if given those constraints you applied some new techniques to reconsider the possible applications for your technology,

Results: Generate a list of at least three alternative applications for the technology. Indicate how this list was generated.

TABLE 11: Generating alternative applications for technology

\begin{tabular}{|l|l|}
\hline Alternative Applications & How ideas were generated \\
\hline & \\
\hline & \\
\hline & \\
\hline
\end{tabular}




\section{WHAT DECISION MAKING PROCESS DO YOU USE TO DETERMINE WHICH APPLICATIONS TO PURSUE?}

\section{Type of question}

Variable: Technology/Product

Section of Plan: Strategies and Tactics

Why is this important?

Any organization has limited resources (financial, human, time) and can conceive of more applications or products than its management has time to pursue. In order for your company to survive, it is important that you spend those precious resources on projects which have the greatest likelihood of commercial success.

\section{Activities and background}

Robert Cooper, author of Winning at New Products describes various project evaluation techniques, both quantitative and qualitative ir nature. He suggests that companies consciously try to improve their ability to select those projects which are commercial winners. To a large extent, as an SBIR recipient, "winner" can be defined in two ways: "winning" at receiving grants and "winning" in the marketplace. These are not the same thing. Our" focus will be upon "winning" in the marketplace.

Cooper suggests that you begin by taking a look at how decisions are made within your organization regarding which projects (applications or products) are selected. He then recommends that potential projects be screened on "must" and "should" matrices. Sample "must" criteria include " Is it technologically feasible to design and develop the product?; Is the product's potential at least $\$ \mathrm{X}$ million?; Does it fit within the new product mandate for our company?" (Cooper, 1986, p. 114). The "should" criteria are measures of attractiveness. These criteria should be developed uniquely for your company.

\section{Have I answered this question adequately?}

Process: The purpose of this activity is to raise your level of awareness regarding the decision making processes that you currently use. This is covered now, in anticipation of the strategy section covered in Chapter 8 . At that point you will need to make decisions regarding your R \& D strategy. You will have addressed this question adequately if you scan Winning at New Products by Robert Cooper and begin to formulate in writing a selection process which is most appropriate for your company.

Resuits: Describe the process presently used by your company for selecting applications or products to pursue. Indicate how good has your track record been in the commercial arena? How could your effectiveness be improved. 


\section{WHO'S THE CUSTOMER? WHO'S THE END USER?}

\section{Type of question}

Variable: Customer

Section of Plan: Markel

Why is this important?

Many technology-driven companies fail to talk to potential customers early in the technology/product development process. The tendency is to assume that many people will want the technology and that the technology or product addresses a real need. However, as the ultimate survival of your business depends upon the purchases made by customers, it is vital to ask the customer what they want early in the development process.

For the technology-driven company, the customer has to quickly shift from being a hypothetical construct to a tangible entity. The earlier you can talk to potential customers, the quicker you can begin to articulate customer specifications and save development time and dollars. The first thing that needs to be clarified is the difference between the end user and the customer. The "end user" is the eritity which will ultimately use the product. However, the "customer" is the one who purchases it. End users and customers are not necessarily the same. Suppose that you successfully develop a cold fusion process, the customer would be the organization(s) that purchases or licenses this technology. By contrast, the "end user" might be the individual whose home is heated by this alternate energy source. The "end user" would not be your "customer."

When trying to ciecide who is your customer, begin by determining who will purchase this item. Is it a technology/product to be purchased by Fortune 500 companies, government agencies, utilities, foreign companies, consumers, etc. Deciding who your customer(s) is, is the first step in looking at the market.

\section{Activities and background}

In the Malcolm Baldridge Quality Award much consideration is given to "customer satisfaction." In fact, it is the single category to receive the most points (300 out of 1000 total points). Key areas that a company is expected to address in the area of "customer satisfaction" include

- process for identifying potential customers and their needs and expectations,

- frequency and types of data collected through interviews, surveys, and other contacts,

- relative importance of various features - "customer specifications"

It is important for you to take stock of what processes your organization has in place to address these issues.

\section{Have I answered this question adequately?}

Process: You have answered this question adequately when you have talked to at least five potential customers and determined their needs (relative to your technology/product) and specifications. How you gather this information will be in great part determined by the degree of protection you have in place for your intellectual property.

Results: List your potential customers. Also, describe the process your company uses to determine customer specifications and how frequently you talk with potential customers. If you presently have no customers, try calling a couple of potential customers and begin a dialog. 
You will have answered this question adequately when you have produced a matrix listing customer requirements (based on your interaction with the customer) and your product specifications, designed to address the customer requirements. Use Table 1210 . assist you in organizing your data.

TABLE 12: Customer Requirements and Product Specifications

\begin{tabular}{|c|c|}
\hline Customer Defined Specifications & Actual Product Specifications \\
\hline Example: & Cost per kilowatt $=\$ .125$ \\
\hline & \\
\hline & \\
\hline & \\
\hline
\end{tabular}




\section{WHO WILL BENEFIT FROM THESE APPLICATIONS?}

\section{Type of question}

Variable: Customer

Section of Plan: Market

\section{Why is this important?}

Another way to approach the question of customers, is to ask a different, but related question -i.e. "Who would benefit from these applications?" This question usually expands the range of possible customers, as the entity that might benefit from this application may not already be in this business. The potential beneficiary, however, might be interested as this application might represent a good diversification effort.

\section{Activities and background}

Many times when trying to define the range of customers, one stops with the obvious. Looking at who would benefit from these applications expands the range of possibilities during the divergent thinking stage of this process.

\section{Iave I answered this question adequately?}

Process: For the time being you can consider that you have answered this question adequately if the list of beneficiaries has more names than the list generated in response to the question "Who is your customer?"

Results: While being as specific as possible, list those entities that might benefit from this application. In other words, rather than listing an industry such as "utilities," name specific companies.

You should generate a list which has at least three domestic and one international customer by name for each of the potential applications generated earlier. 


\section{WHAT IS YOUR SUSTAINABLE COMPETITIVE ADVANTAGE?}

\section{Type of question}

Variable: Technology/Product

Section of Plan: Executive Summary and Mission Statement

Why is this important?

A potential investor will want to assess the "staying power" of your technology and your company in the marketplace. Your "sustainable competitive advantage" is a description of those aspects of your company and technology that should enable it to survive and flourish.

\section{Activities and background}

The types of things that provide "sustainable competitive advantage" include:

- intellectual property: patents, trade secrets, copyrights, trademarks

- the uniqueness of the technology and the limited number of people who have expertise in this area (hopefully many of them are employed by your company)

- cost of entry

- various other advantages that enable you to be quicker, less expensive

- your track record with respect to selecting successful new products or technologies, as well as your ability to keep to development timelines

- other organizational strengths: your marketing or sales capability; access to distribution network; quality of your work

- your strategic alliances, champions

In other words all those characteristics which give you and your technology/product advantage over another.

\section{Have I answered this question adequately?}

Process: You will have answered this question sufficiently if you have spent several hours discussing this with key people in your organization. You should then ask for input from trusted outsiders as a "sanity check." It is difficult to be objective regarding one's own organization.

Results: List all those characteristics which comprise your "sustainable competitive advantage." Then formulate a statement of your "sustainable competitive advantage," with concurrence from members of your team and "outside experts." 


\section{WHAT IS YOUR COMPANY'S ORGANIZATIONAL STRUCTURE?}

\section{Type of question}

Variable: Management

Section of Plan: Management

Why is this important?

Just as the performance of a football team depends in large part upon the skills of the coach, the perfornance of a company depends upon its management team and how it responds to changing conditions and challenges. Your management and the company structure will be scrutinized by a potential investor. It is important.

\section{Activities and background}

List the members of your management team and describe their role and responsibilities. Highlight those items from each person's background which would convince an investor that they are capable of fulfilling this role well. Business and scientific accomplishments are both important. Do not slight the business accomplishments.

\section{Have I answered this question adequately?}

Process: For the time being, you will have given this adequate attention if each member of your management team spends several hours thinking about those experiences and events which will give a potential investor confidence.Types of things to be included should reflect managerial experience, success in obtaining funds, consulting done with potential customers, relevant research completed, and the like.

Results: Sketch out an organizational chart, highlighting the roles that exist within the company. It is understood that your organization is probably quite small, nonetheless an organizational chart can be very useful. Develop a one page description for each member of your management team, highlighting their business and scientific accompiishments. This one page description should be geared towards a business audience and include attention to those items that would give a potential investor confidence.

Also indicate voids in the management structure on your organizational chart. 


\section{WHAT IS YOUR VISION?}

\section{Type of question}

Variable: Company

Section of Plan: Goal

\section{Why is this important?}

You can't begin to map out your financial, marketing, R \& D, and manufacturing strategies until you decide where you want to go. Many companies approach their growth solely in an opportunistic fashion. Although one should always remain open to opportunities and examine their potential, without a vision for your company's future you have nothing to pull you forward.

\section{Activities and background}

Envisioning what you want to be five years from now is "blue sky-ing it!" However, that's what is required at this point. Spend some time with your management team sharing visions for the future around each of the items listed below. Come to some consensus. If you are a sole proprietor, it would be advisable to find a trusted party with whom you can brainstorm, so as to interject some other thoughts and enrich your thinking process. Your Dawnbreaker facilitator will also react to this.

\section{(1) PRODUCTS and SERVICES}

What products and services will your company be providing?

What type of work will you be doing: research, development, marketing, manufacturing, distribution?

\section{(2) IMAGE}

How will your organization be viewed by others?

How will you operate within the organization-philosophy?

What type of employee involvement plans do you have?

What will differentiate you from other companies?

\section{(3) WHAT WILL YOU LOOK LIKE IN THE FUTURE?}

How large do you want to become?

Where will your business be located?

\section{(4) MARKET GOALS}

Who will be your customers?

What geographic region will you serve?

What \% of market share will you possess?

Will you be a dominant player in your defined market niche?

\section{(5) FINANCIAL GOALS}

What are your financial goals for five years from now?

What will your companies revenue stream look like?

What will your profit margin be? $10 \%, 15 \%, 25 \%$, etc.

\section{Have I answered this question adequately?}

Process: At this time the most important thing to do is to set aside the time to develop your organization's vision, involving in the process those people who you consider to be appropriate. It should be more than one person. If you just jot down answers to these questions on your own, you will not be garnering the most benefit from this process.

Results: Summarize your vision by providing one sentence responses to each of these questions listed above. Classify them under the five goal subheadings: Product, Market, Financial, Image, and Future. 


\section{SUMMARY}

The overall purpose of preparing Interim report \#2 is to:

- raise your level of awareness,

- encourage you to collect data regarding applications for your technology/product,

- begin to document areas of weakness.

You should anticipate that as you begin to gather more data, your mind map will begin to change.

Interim Report \#2 should be mailed to Dawnbreaker by June 14th. (Do not send us your only copy,) The report should contain responses to the following questions (from the Results sections), organized in a fashion which will make it easier for you to work with as you develop the plan:

What is your technology/product?

What are possible applications of your technology?

Who is the customer? Who is the end user?

Who would benefit from these applications?

What is your sustainable competitive advantage?

What is your vision?

What is your company's organizational structure? 


\section{CHAPTER 7: INTTERIM REPORT \#3}

\section{WHERE ARE WE?}

To help you keep your sights focused, we will begin each of the following three chapters by taking stock of where you are in this process. As you will notice, from this point forward the amount of work required and the complexity of the data you will be managIng will accelerate rapidly.

Interim Report \#1 involved benchmarking your starting polnt either by providing us with a copy of your existing business plan or by responding to the questions in the Mind Map. Preparation of Interim Report \#2 required that you examine fundamental issues including potential applications of your technology, the nature of your potential customer base, and your vision for growth.

As you enter this chapter, you will still be surfacing data relative to the various applications and/or markets that you mentioned in preparation of Interim Report \#2. The reason for proceeding in this fashion is that your decision regarding the best applications to pursue should be based upon the data you are gathering. As we proceed through this chapter, we are assuming that you do not yet have sufficient information on which to make a good decision regarding the most lucrative applications to pursue. As indicated in Chapter 1, the decision to pursue specific applications is in large part determined by your assessment of the likelihood of obtaining funds to continue research and development or commercialization. Market size, market readiness, technological leap-frogging, and other variables discussed in this chapter are important to consider. These variables have an impact on the likelihood of funding from the various sources referenced in Chapter 2.

If you have an existing plan, it is recommended that you take this opportunity to reevaluate the course of action your company is pursuing by following the procedure outlined in this Section of the book. The dynamic nature of the world in which we live requires frequent re-examination of a company's operating beliefs. In a conversation several years ago with Zenas Block of New York University, I was struck by his comments regarding meeting objectives. He argued very persuasively that the ability of a management team to fulfill its objectives was not necessarily a good reflection of its skills. A better index was its ability to make good decisions about when to change its course of action. Just as a good ship's captain changes course when conditions become inclement, so should a good management team. To adhere to the same course of action because it was projected carlier could have the same devastating effects for a business as it would for a ship encountering adverse conditions. Management teams, as compared to ships' captains, can become so absorbed in daily operations that they may not readily detect the changes occurring around them. It is important to take the opportunity to reevaluate conditions with some frequency. Re-evaluation either reconfirms the course of action one is taking or gives pause to consideration of altematives.

Schedule: This assignment is due by July 5. As indicated previously, until the final business plan is written, the form in which the information is received is unimportant. What is vital however, is the quality of the thinking $:$ hich precedes it.

Tasks: There are 16 tasks associated with the preparation of Interim Report \#3. Each task consists of conducting the research needed to answer each of the questions in Table 13. 
TABLIE 13: Project planning guide for Interim Report \#3

\begin{tabular}{|c|c|c|c|c|}
\hline Questions & Responsible & $\begin{array}{c}\text { Also } \\
\text { Involved }\end{array}$ & $\begin{array}{l}\text { Keep } \\
\text { Informed }\end{array}$ & $\begin{array}{c}\text { Completion } \\
\text { Date }\end{array}$ \\
\hline $\begin{array}{l}\text { Who would be alfected by theses } \\
\text { appilications? }\end{array}$ & & & & \\
\hline 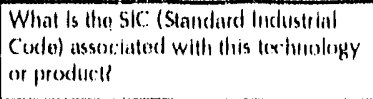 & & & & \\
\hline 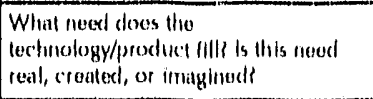 & & & & \\
\hline 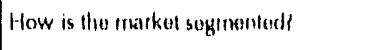 & & & & \\
\hline What is your Irission? & & & & \\
\hline What is the growth rate of this markets & & & & \\
\hline $\begin{array}{l}\text { What is the size of the matkel (dounestit } \\
\text { and internationalis }\end{array}$ & & & & \\
\hline $\begin{array}{l}\text { What are the trikle jourrtrals for this } \\
\text { "markett }\end{array}$ & & & & \\
\hline Who are the compentitors in this mathet & & & & \\
\hline $\begin{array}{l}\text { Who olso is expected to entur this } \\
\text { markett? }\end{array}$ & & & & \\
\hline $\begin{array}{l}\text { What regulititory ageneriess hive int } \\
\text { inpact on this indististy? }\end{array}$ & & & & \\
\hline 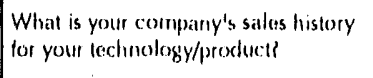 & & & & \\
\hline $\begin{array}{l}\text { What are the characteristics of these } \\
\text { competiturs al prosentre }\end{array}$ & & & & \\
\hline 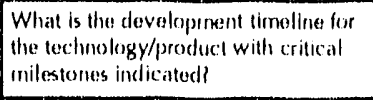 & & & & \\
\hline $\begin{array}{l}\text { What kind of mantufacturing does the } \\
\text { cornpinty perforn? }\end{array}$ & & & & \\
\hline What are your financial requirererrentils? & & & & \\
\hline
\end{tabular}

Time: You will need to allocate time to conduct the research required in order to answer each of these questions. The tasks involved in completing Interim Report \#3 require the following cognitive skills: data gathering, number-crunching and re-evaluation. Once your data gathering needs are clarified, these activities could be carried out by someone else, for example, a consultant, graduate student, SBDC, SCORE, or a staff person. However, it is important to clarify the form in which you will need the information compiled, so that you may assimilate it as quickly as possible. You will need to use these data in developing strategies. Make certain that the people involved with data gathering understand your deadlines. 
TABLE: 14: Cognitive Skills required in preparation of each Interim Report

\begin{tabular}{|c|c|c|c|c|c|}
\hline $\begin{array}{c}\text { Cognitive } \\
\text { Skills }\end{array}$ & $\begin{array}{c}\text { Mind } \\
\text { Map }\end{array}$ & Report 2 & Report 3 & Report 4 & $\begin{array}{c}\text { Business } \\
\text { Plan }\end{array}$ \\
\hline data gathering \\
\hline $\begin{array}{c}\text { number } \\
\text { crunching }\end{array}$ & $x$ & $x$ & $x$ & $x$ & $x$ \\
\hline $\begin{array}{c}\text { business plan } \\
\text { writing }\end{array}$ & $x$ & $x$ & $x$ & $x$ & $x$ \\
\hline $\begin{array}{c}\text { review } \\
\text { decision making }\end{array}$ & $x$ & $x$ & $x$ & $x$ & $x$ \\
\hline strategizing & $x$ & $x$ & $x$ & $x$ & $x$ \\
\hline re-evaluatlon & $x$ & $x$ & & $x$ \\
\hline
\end{tabular}

Report format: In organizing Interim Report \#3, it is suggested that each question be addressed on a separate page(s). The top of the page should contain the following

- the question

- the variable to which this question is related

- the name of the section of the business plan to which it is related

- the names of the people involved with gathering the information

- the date

Be sure to also include the re-evaluation and your response to Dawnbreaker's feedback. 


\section{WHO WILL. BE AFFECTED BY THESE APPLICATIONS?}

\section{Type of questlon}

Varicable: Markel

Section of Planl: Markoh, Conilngencios

\section{Why is this important?}

You might view this cuestion as a repeat of one previously cited, however, il is diflerent. The purpose of this (juestlon is to surfince the ldentity of the 'stakeholders'. In other' wordis, who would be aflecied by this application - both adversely and lavorably, If they are adversely alfected how might they reacl? What kind of resistance would they present? What kind of stritegles will you noed to develop to Hddress this resistance.

\section{Activities and background}

Cenerale a lint of stakcholders by calegory (i.c. Oll Companies, Gas Companles), as well as by compuny nume (Shell, ARCO, Monsanto, etc.). Indicate how they might be affected and whal kind of resistance they might pose.

\section{Have I answered this question adequately?}

Process: For the time being you will have addressed this question adecuately when you have generated a list identilying $3-5$ companies for cach application and have identified their potential responses.

Reswlts: Generate the list described above for each application. 
TABLE 15: Stakeholder mapping

\begin{tabular}{|l|l|l|}
\hline & \multicolumn{2}{|c|}{ Potential Stakeholders } \\
\hline Applications & Companies & How affected? \\
\hline & & \\
\cline { 2 - 4 } & & \\
\cline { 2 - 4 } & & \\
\hline \multirow{5}{*}{} & & \\
\hline & & \\
\hline & & \\
\hline & & \\
\hline & & \\
\hline & & \\
\hline & & \\
\hline & & \\
\hline & & \\
\hline & & \\
\hline & & \\
\hline
\end{tabular}




\section{WHAT IS THE SIC (STANDARD INDUSTRIAL CODE) ASSOCIATED WITH THIS TECHNOLOGY OR PRODUCT?}

Type of question

Variable: Tochmologgy/lerelucel

S'ertionl of P'lant: Markel

\section{Why is this important?}

Slandard Industrial Codes (SIC) functlon as keys, unlocking vast stores of information housed in databases. Orgginally developed by the Bureau of Standards, SIC codes are alssocialed with most lechonologles, industrles, products, and services. This numbering system is referenced widely and provides a falrly casy way to cut durough vast amounts of clatia. Cilven thal most ol' you are working whth lairly new technologles, you may not be able fo lind a SIC code whlch exacily lits your specialty. You may have to move up to a broader class. For example, if your product is a Hypothermia Suit, you would not expect Io find an SIC code for this one-of-a-kind product. However, a Hypotherma Suit is an exalmple ol protective clothing, emergency gear, or outerwear. You could start by looking for SIC codes to cover these broader calegory, If you further assume that the markets are winter sportsmen and automobile drivers, you would also look for SIC codes that best represent with these groups.

$\begin{array}{llll}\text { Narrow Class } & \text { Broader Clasi, } & \text { Broadest Class } & \text { Related Market } \\ \text { hypothermiasuil } & \text { protectlve clothing } & \text { clothing } & \text { sportsmen } \\ & \text { cmergency gear } & \text { emergency } & \text { automobile } \\ & \text { outerwear } & & \end{array}$

\section{Activities and background}

Find the closest SIC codes that refer to your technology/product and related markets and industries. The best place to seck this information is to incuire at the library. Ask the reference Ilbrarian in the business section for assistance with finding appropriate SIC colles.

\section{Have I answered this question adequately?}

Process: You will have answered this adequately when you have obtained SIC codes for your techonology/product for all the applications surfaced in Interim Report \#2, and related markets and industries. Numerous potentlal lnvestors with whom we are familiar indicated that they would like to see early consideration given to the full range of possible applicalions before the scientist makes the decision to focus.

Resilts: List the SIC codes that you found that relate to your technology/product; related markets; and industrics. Map out the process that you used to find the SIC code, akin to the strategy provided above for hypothermia suits. 
TABLE 16: SIC codes for markets, industries, technologies, and products

\begin{tabular}{|l|l|l|}
\hline Applications & Market Descriptors & SIC codes \\
\hline & & \\
\cline { 2 - 4 } & & \\
\cline { 2 - 4 } & & \\
\hline & & \\
\hline & & \\
\hline & & \\
\hline & & \\
\hline & & \\
\hline & & \\
\hline & & \\
\hline & & \\
\hline & & \\
\hline & & \\
\hline & & \\
\hline & & \\
\hline & & \\
\hline & & \\
\hline
\end{tabular}




\section{WHAT NEED DOES THE TECHNOLOGY/PRODUCT FILL? IS THIS NEED REAL OR IMAGINED?}

\section{Type of question}

Variable: Market

Section of Plan: Market

\section{Why is this important?}

The only way that you or an investor will realize a return from his investment is from the sale of your technology or product. Considerable emphasis is therefore placed upon trying to understand the "buyers" or "customers" for your technology/product. It is common for technologists and inventors alike to assume that the customers are there and that they will buy. However, this fundamental assumption needs to be tested.

\section{Activities and background}

In a book entitled Winning at New Products Robert Cooper summarizes the results of numerous case studies and describes the most common reasons for new product failure (Cooper, 1988).

- $28 \%$ of the cases fell into the category known as "The better mousetrap nobody wanted." For the most part, these were technology-driven companies that assumed what the customers wanted without asking them.

- Another $24 \%$ of the failures were described as "The 'me too' product mects a competitive brick wall." These products were clones of existing successful products that did not offer the customer a reason for switching brand loyalty.

- $15 \%$ failed because they were "Technical dogs" - they simply didn't work.

- The remaining cases failed due to "Marketing one-upmanship" (13\%), price crunch (13\%) and environmental ignorance (7\%).

To avoid creating "The better mousetrap that nobody wants" talk to your customers. In previous activities you have generated a list of potential customers, probably at the company level. Your next step should be to find the names of individuals within those companies and call them. Ideally, you should press for a face-to-face meeting with a potential customer. However, if this is not feasible given his geographic location, interview him by phone. Before calling develop a script. Key things to include in your script are (1) Who you are, (2) Why you are calling, and (3) Various questions designed to elicit an unders canding of customer needs and specifications. Before calling, also decide what information you can and cannot share about your company's research activities. Be prepared, in case they ask.

When trying to locate the names of people to call, there are various approaches that you can take.

(1) Find names of individuals in companies of interest from pertinent Conference Proceedings, journal articles, and associations.

(2) Call the switch board of the appropriate company and ask who is in charge of marketing, sales, new product development, or R \& D depending on what department is most appropriate, given your situation.

(3) Call manufacturers representatives in order to learn in what items "end users" seem to be most interested. 
It may take several calls to find the correct person with whom you should speak. Start by calling potential customers who are potentially of least importance to you, so that you have an opportunity to become comfortable with this process. Be sure to send them a follow-up letter thanking them for the time that they spent lalking with you. Write within a week of making the call.

\section{Have I answered this question adequately?}

Process: You will have answered this question adequately when you can complete the chart below. Real customers should have a contact person name, a date of contact, and a customer specification. Research conducted with the Myers Briggs Type Indicator reveals that most scientists are introverted. Thus, if you find yourself avoiding contact with potential customers reflect upon this point and deiermine if this is an issue with you. There is no substitute for getting to know your potential customers and developing a personal relationship with them. If you avoid this important step, consider who else within your organization can assist with this vital activity.

Results: In your write-up indicate if your customers are real or imagined. "Imagined customers" are those whom you assume to be customers, but with whom you have not spoken. For example, you may assume that IBM is a customer for your technology, but you may not have spoken with anyone at IBM. In this context, a "real" customer is onc who indicates that there is a need for $\mathrm{X}$ and who can provide some information regarding "customer specifications." An example of a customer specification would be that the energy produced must cost no more than $\$$.XX per kilowatt hour. 
TABLE 17: Creating real customers

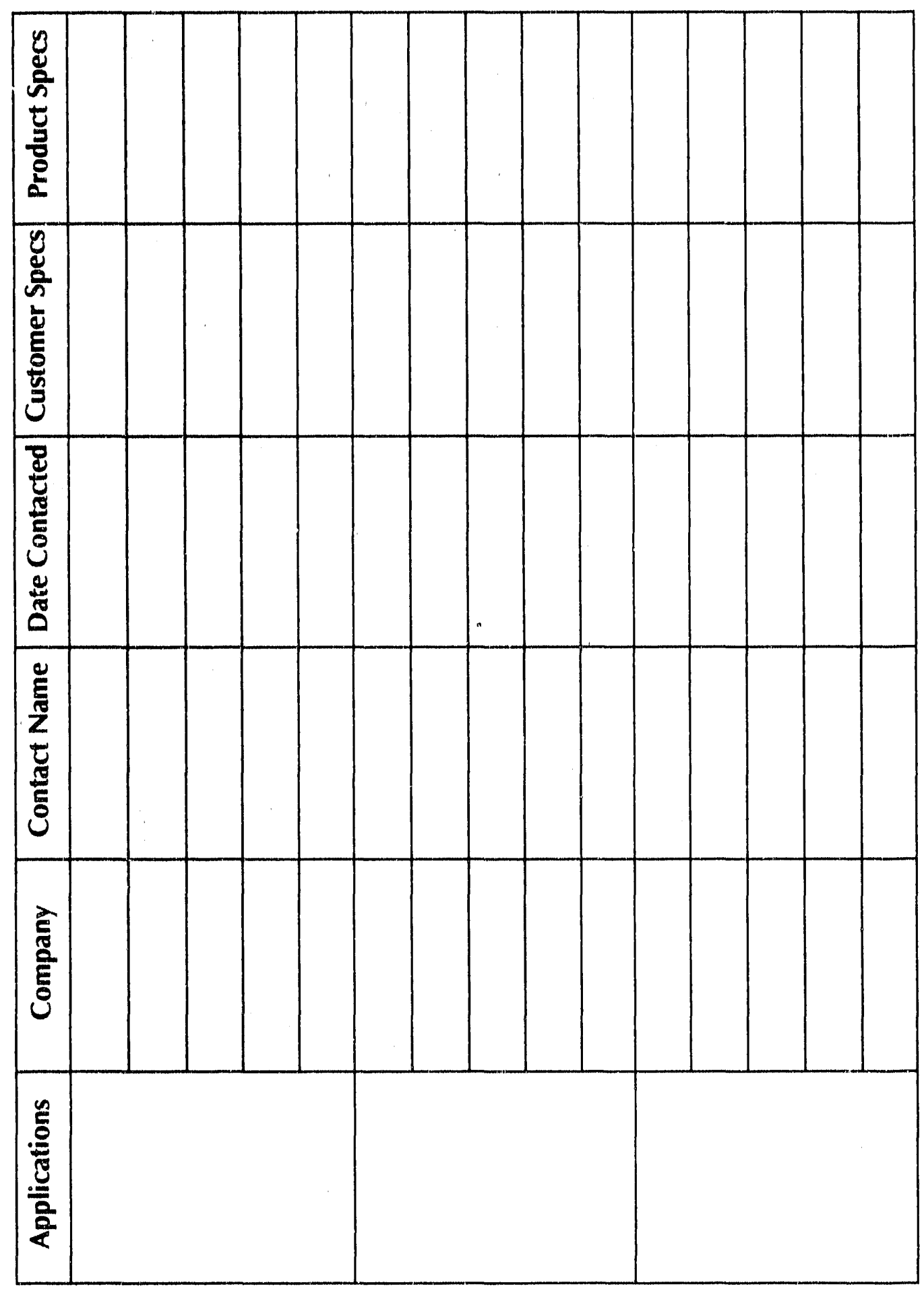




\section{HOW IS THE MARKET SEGMENTED?}

\section{Type of question}

Variable: Market

Section of Plan: Market

\section{Why is this important?}

The process of segmenting your market provides focus and serves as a means of obtaining a clearer understanding of your market. An excellent resource to examine in this regard is Competitive Marketing Strategies by James W. Taylor (1986).

\section{Activities and background}

Segmenting the market appropriately is an art and takes considerable time and effort. Common ways of segmenting a market are listed below. See T'aylor, P. 34 for more detailed descriptions of these market segments.

\section{CONSUMER}

Demographics

Geographic

Psychographic

Buyer Behavior

Marketing Conditions

\section{INDUSTRIAL}

$\mathrm{SIC}$

Technology

Organizational Characteristics

Purchase Characteristics

Product Characteristics

Taylor provides three criteria for deciding if you have segmented the market appropriately,

(1) Is the segment definable in some operational way?

In other words can you accurately quantify how many customers are in this segment? For example, if I define a market segment by' using the following demographic variables children under five feet tall with freckles - I would probably have difficulty quantifying potential customers in this niche. It is highly unlikely that I would find any organization sorting data in this fashion, thus making it difficult for me to quantify.

(2) Can you reach this segment effectively through affordable advertising?

Affordable advertising can include things such as face to face meetings and phone calls. Do not assume that advertising means only print copy.

(3) Is it small enough for you to dominate and large enough to provide good profits?

The most common error that companies make is to fail to segment their market appropriately. Apply the preceding criteria to see if the manner in which you have segmented your market is effective. You may wish to try slicing the market in various ways in order to determine which approach makes more sense.

\section{Have I answered this question adequately?}

Process: You will have answered this question adequately if you can provide specific, quantifiable data regarding the market segment.

Results: Indicate how you have segmented your market, making reference to the methods listed above or others which you may have used. Next, specifically indicate the manner in which you will quantify the number of customers and/or units sold in that segment. Indicate which methods are available to you to reach that segment and how much those methods will cost. You will probably need to wait until the financials have been developed in order to apply the third criterion. 


\section{WHAT IS YOUR MISSION?}

\section{Type of question}

Variable: Company

Section of Plan: Business

Why is this important?

Being able to describe your business in a very succinct fashion is a selling tool. You should be able to clearly and simply express the essence of your tusiness in one sen. tence.

\section{Activities and background}

A good mission statement should answer the following questions.

- What business are you in? This question is answered by indicating the types of work your company performs such as $\mathrm{R} \& \mathrm{D}$, Engineering, Manufacturing, Marketing, Custom Design, and Distribution.

- What products and technologies are involved?

- What markets do you serve? Indicate those markets which you previously represented by SIC codes. Indicate how you segment the market.

- What is unique about your company? What differentiates it from others'?

\section{Have I answered this question adequately?}

Process: You will have answered this adequately if you can generate a mission statement which is no longer than 50 words.

Results: Try writing a pithy statement describing your company's mission. The following is a good example:

"Voltec, Inc. designs, manulactures, and markets the only U/L approved, high efficiency computer-controlled power combustion gas fired boilers and heaters to the Real Estate, Education, Health Care and Service Sections of the HVAC market in the commercial and industrial segments."

Although this statement is very dense, it contains all the elements required. 
WHAT IS THE GROWTH RATE OF THIS MARKET?

Type of question

Variable: Market

Section of Plan: Market

\section{Why is this important?}

Conditions which affect the rate of growth in a market frequently change. Such conditions include change in demographics, technology, regulations, and other economic conditions. In predicting the rate of growth in your company's business it is important to consider trends which are affecting the rate of growth.

\section{Activities and background}

Industry journals and associations continue to be among the most valuable resources used to detect market trends in high technology. The Encyclopedia of Associations, a common reference in most libraries, is commonly used to gain the names of contacts and data.

Another excellent resource to consult for information on market trends is the United States Industrial Outlook produced annually by the US Department of Commerce. This is a basic reference, providing information on over 350 industries. It is available in most libraries.

Other sources that can be consulted for domestic data include The International Trade Commission and the International Trade Administration. Both of these sources provide excellent information on market trends.

The International Trade Commission produces a list of the free reports which they have available. You can obtain a copy of the"Selected Publications of the United States International Trade Commission"by calling 202-2252-1807 or writing

The International Trade Commission,

Attention: Publications

701 E Street NW, Washington DC 20436.

The International Trade Administration employs over 350 industry analysts who also provide free information. You can request a copy of the ITA Directory of Services and Employers, which is a listing of their industry analysts. There is a nominal fee. You can request by calling 202-377-2000 or by writing

US Department of Commerce

International Trade Administration, Room 4805

Washington DC 20230.

The Department of Commerce can be contacted regarding information on international trends. You can find out what information is available by calling 202-377-3181 or by contacting the

US Department of Commerce

Export Promotion Service

Cffice of Inforntlition Product Development and Distribution

PO Box 14207

Washington DC 20044 


\section{Have I answered this question adequately?}

Process: You will have answered this question adequately if' you consulted each of the resources listed above and completed Table 18

Results: For each of the SIC codes that you selected previously, as well as for each of the market that you segmented, seek information on market trends (past and future). Compile these in the Table provided.

TABLE 18: Market trends

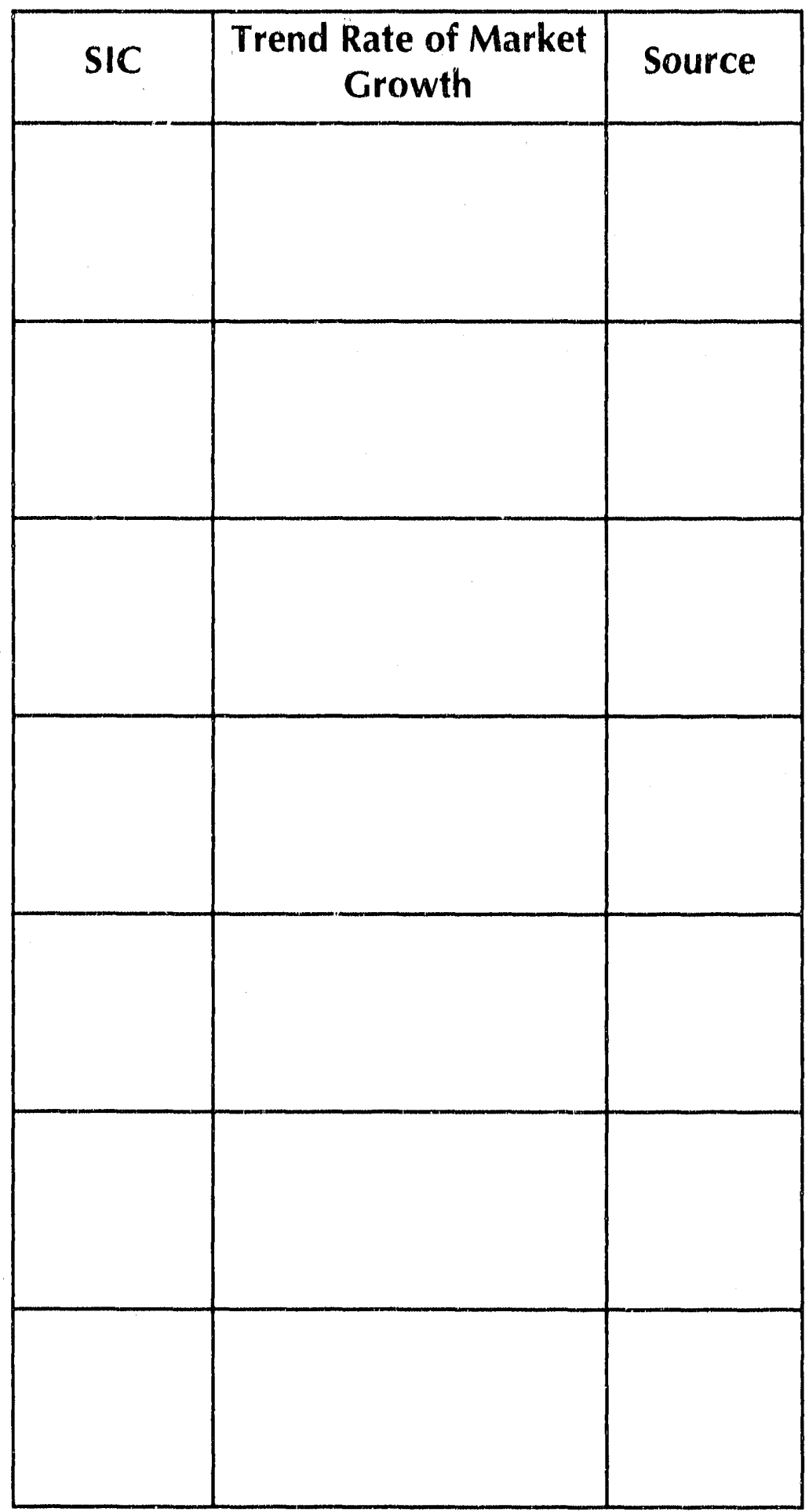




\section{WHAT IS THE SIZE OF THE MARKET?}

\section{Type of question}

Variable: Markel.

Section of Plan: Market

\section{Why is this important?}

The phrase "size of the market" or "market size" rel'ers to the potential of the market in dollars, units, or both. This concept is applied to all segments for which the product is appropriate. The "size of the market" is the limit that one can hope to obtain. Keeping in mind Taylor's comment about competing in market niches in which one can become a dominant player, how the market is sized is very important.

If the size of the market is too small, a potential investor will not be interested in investing as the return on investment may not be attractive. If the market size is fairly small, the entrepreneur should reconsider if the technology/product is worthwhile pursuing or if he should reconceptualize how the market is segmented. Market segmentation is fluid and has profound "decision implications" for everyone involved.

\section{Activities and background}

Frequently, it is very difficult to obtain exact numbers on the size of the market. This problem is amplified if the product is new. The first place to start in trying to determine market size is to contact various sources to see if these statistics have already been compiled by someone else. Listed below are some of the more common resources one can approach.

Government Statistics: Data on market size might be available from the government resources mentioned earlier.

Associations: The Encyclopedia of Associations is an extremely valuable resource found in most libraries. This three volume set is produced annually and contains an index and two accompanying volumes. There are associations for almost every item imaginable. Every entry contains the name of the Association, its services, membership and a contact person. The Associations will indicate if they collect statistics. If they do collect statistics, call the contact person and inquire if they can sort the data in the manner of interest to you (your segmentation technique).

Dialog: As mentioned earlier Dialog is an on-line retrieval service that allows you to obtain information from hundreds of databases. If you do not already use this service, you can contact a public or university library to see if they can conduct a search for you. Searches are done with key words, using Boolean logic. You could request a search on "Market size" and whatever item you are trying to size. There is a fee for searching.

Journalists and Futurists: Another way to obtain information is to contact journalists and futurists who have written articles on the industry in question. When you find a valuable article, contact the editor and ask him to provide you with the phone number of the author. Contact the author and see if he has come across any information on "market size"

Findex: The Directory of Market Research Reports, Studies, and Surveys: This resource is found in large libraries and lists published market research reports. For the most part the reports are quite expensive. However, if you find the name of a research report of interest, you can contact specialty libraries in your area and see if they have a copy that they will let you sec. Corporate libraries are most likely to have such reports. 
Bob Berkman, the author of Eind It Fast, has various tips for talking with experts and for gaining access to specialty librartes. These are described in his book.

Model Building: If you cannot find any data available on your product, you can take other approaches to size the market. The most common approach is to select another product that is similar or that fulfills the same function and to seek data on that surrogate product. In this case, your aim is to develop a reasonable model that will enable you to size the market in terms of "units" and work up the dollar value at a later time.

Another important concept to consider when sizing the market is the difference between the total market and the served available market. The served avallable market defines the market niche in which the company is operating in more precise terms. This precision enables the company to isolate the niche in which it can aim at becoming a dominant player. By contrast, the total available market is the larger, related market in which one is operating. For example, if a company produces heaters, the total market would be the heater market, defined in heater units and accompanying dollars. However, if the company produces a heater with specific product characteristics i.c. a small heater that produces 300 btu's, those product characteristics come to define the served available market. In other words, this product competes within a subset of the market, defined as small heaters producing 300 btu's. The company's product does not compete with all heaters on the market. The subset defines the served avallable market and is the market niche of interest.

\section{Have I answered this question adequately?}

Process: For the first go round, you will have answered this question adequately when you have consulted all of the sources referenced above and obtained data to determine the size of the total and served available markets.

Results: For each of the market segments that you have identified indicate what data you have found regarding market size, by completing Table 19. 
TABLE 19: Market size of total and served available markets

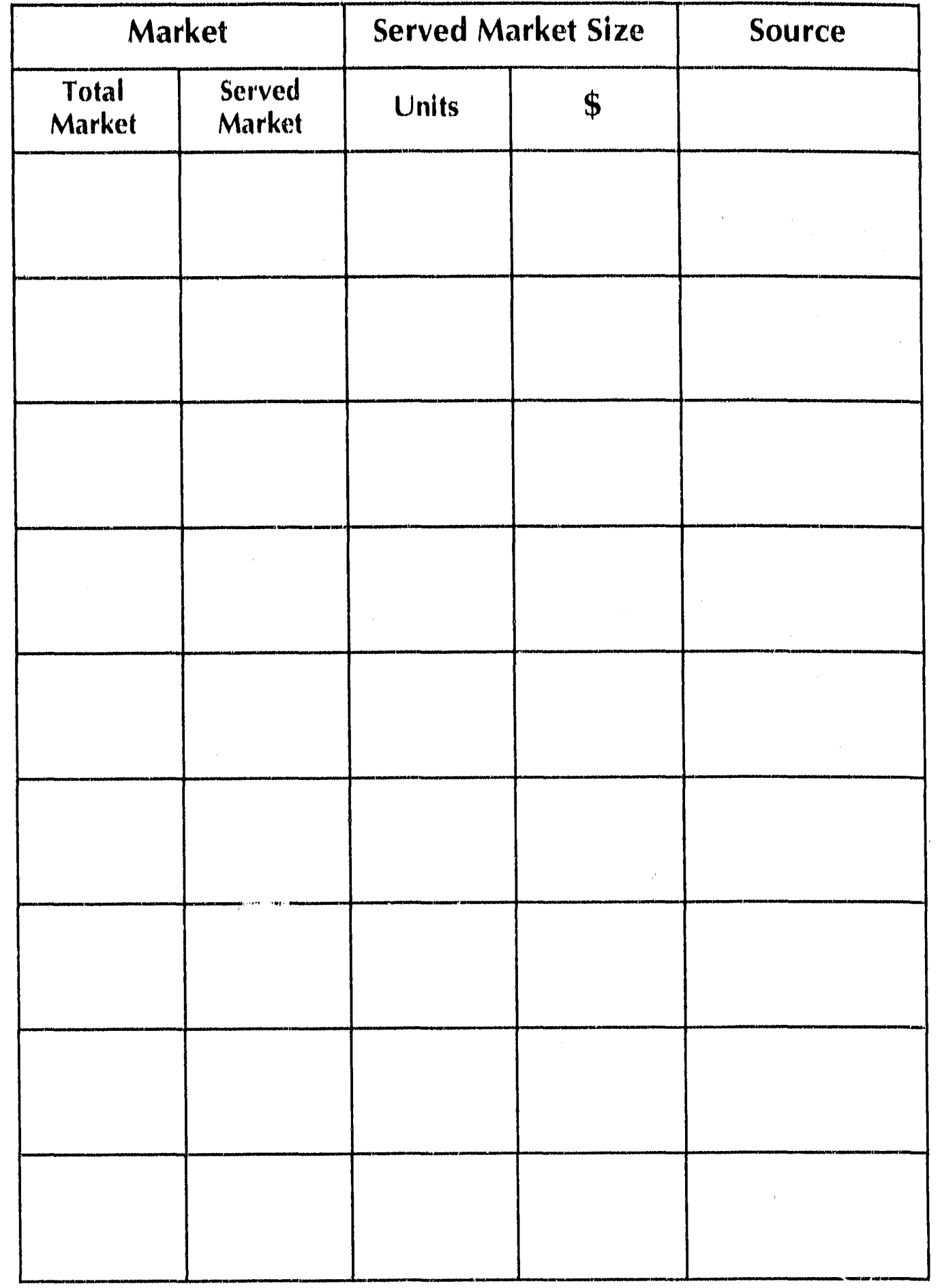




\section{WHAT ARE THE TRADE JOURNALS FOR THIS MARKET? \\ What are the major conferences?}

\section{Type of question}

Varlable: Market

Section of Plan: Market

\section{Why is this important?}

Considerable information and contacts can be found among speciallzed magazines, newsletters, and conference proceedings. Familiarity with the resources for various markets can accelerate your ability to conduct market research.

\section{Actlvittes and background}

Two excellent sources to consult when looking for spectalty periodicals are:

The Standard Pertedleal Directory

New York: Oxbridge Communications, Inc., 1991

Gale Directory of Publications and Broadcast Media

Gale Research, Inc, 1991

These references can be found in most large librarles. The data they contain are similar, but are presented In different fashions. In the Standard Periodical Directory you will find reference to newsletters, magazines, directories, and special reports sorted by topic. Brief descriptions are included, as well as the price, contact person, address and phone number. For example, under the descriptor "Energy," you will find references to resources such as:

- Advanced Fossil Energy 'Technologies

- Air to Air Heat Exchangers

- Alternative Energy Developments

- Bulletin of the Canadian Nuclear Society

- Coals and Synfuels Technology Report

- Gcothermal Energy

- Cogeneration Journal

Gale's Directory covers similar periodicals, but also includes broadcast media. The data in Gale's are sorted in many different ways and contains many tables.

The publications referenced in these two sources tend to be expensive to acquire. You would, therefore, be well advised to consult with private librarles in local industries to determine if they subscribe to these resources.

A useful resource to consult when looking for a listing of conferences, conventions, and trade shows is called Directory of Conventions, published by Successful Meetings. Conferences are sorted by topic, as well as by geographic location. For example, if you check under the descriptor 'energy', you will find that The Energy Engineering Associathon of the World Energy Congress will be holding its next conference between October 30-November 1, 1991. A verage attendance is 3,000. The conference is national in scope and has exhibitor space. The phone number to call for additional information is 404-4475083 .

\section{Have I answered this question adequately?}

Process: Consult these sources, contact those that are of particular interest, and ask the editor to send you a complimentary copy.

Results: Generate a list of at least 10 specialty periodicals for each of the markets of interest. Examine at least one issue of each to determine if the type of information they contain can be useful to you in your market research. 


\section{WHO ARE THE COMPETITORS IN THIS MARKET?}

\section{Type of question}

Variable: Competitors

Section of Plan: Competitors

\section{Why is this important?}

Every company has competitors that are already operating within the market segment of interest. Your resources and skills relative to the other players will affect how profitable your business will be.

\section{Activities and background}

Various resources car be consulted to determine who your competitors are. The most common include

1. Industry journals, local newspapers, customers, suppliers, and trade associations.

2. The Thomas Register of American Manulacturers is a large comprehensive set owned by most major libraries. It is updated annually and lists manufacturers nannes, addresses, and phone numbers. Information is organized alphabetically by product. This is an excellent starting place.

3. Ward's Business Directory of US Priyate and Public Companies provides a llsting of the public companies with largest sales sorted by SIC code.

4. Dialog When looking for more obscure information and/or information on a global basis, Dialog is extremely useful. This searching process can be expensive as you are charged by Dialog for time on-line, as well as associated print costs.

5. High-Tech Directory This resource lists over 800 publicly traded companies specializing in inmovative technology. One can obtain a list by contacting:

Barrington Research Associates

PO Box 860

Barrington, IL 60010

312-382-7788

\section{Have I answered this question adequately?}

Process: You will have answered this question adequately when you have examined the preceding references for information on competitors and begun to develop competitive files on each. You will be asked to analyze the data you are collecting at a later time. Your focus now is to gather the data.

Results: List the major competitors including company name, address, and phone number. Group these by SIC code. 
TABLE 20: Detecting competitors

\begin{tabular}{|l|l|l|}
\hline SIC & Competitors \# & Address \& Phone \\
\hline & & \\
\cline { 2 - 3 } & & \\
\cline { 2 - 3 } & & \\
\hline & & \\
\hline & & \\
\hline & & \\
\hline & & \\
\hline & & \\
\hline & & \\
\hline & & \\
\hline & & \\
\hline & & \\
\hline & & \\
\hline & & \\
\hline & & \\
\hline & & \\
\hline & & \\
\hline
\end{tabular}




\section{WHAT ARE THE CHARACTERISTICS OF THESE COMPETITORS AT PRESENT?}

\section{Type of question}

Variable: Competitors

Section of Plan: Competition

\section{Why is this important?}

Analyzing the competitors' strengths and weaknesses helps you take a more realistic look at your own organization and to develop sound strategies for success.

\section{Activities and background}

The types of information that you can obtain on your competitors depends to a large extent on whether they are privately-owned or publicly traded. Considerably more information is available on publicly traded companies. Leonard Fuld's book entitled Monitoring the Competition provides many helpful hints on how to build up good data files on your competitors.

If the company is publically-owned you can request an annual report, 10-K, 8-K, and 10 $\mathrm{Q}$, from the Securities Exchange. If the company is privately owned the task is more difficult. However, you can develop good data from news articles, product literature and catalogs, price lists, and market studies.

All of this information should be compiled in competitor files.

\section{Have I answered this question adequately?}

Process: You will have answered this question adequately when you have obtained more complete data on your competitors, per the suggestions listed above. In subsequent chapters you will be instructed to analyze the data you are now beginning to collect.

Results: Make a list of the competitor files that you have and indicate the nature of the data that your files contain: 10-K, 8-K, 10-Q, prospectus, annual reports, news articles, product literature, catalogs, price lists, and market studies. Also complete the table below. 
TABLE 21: Creating good competitor files

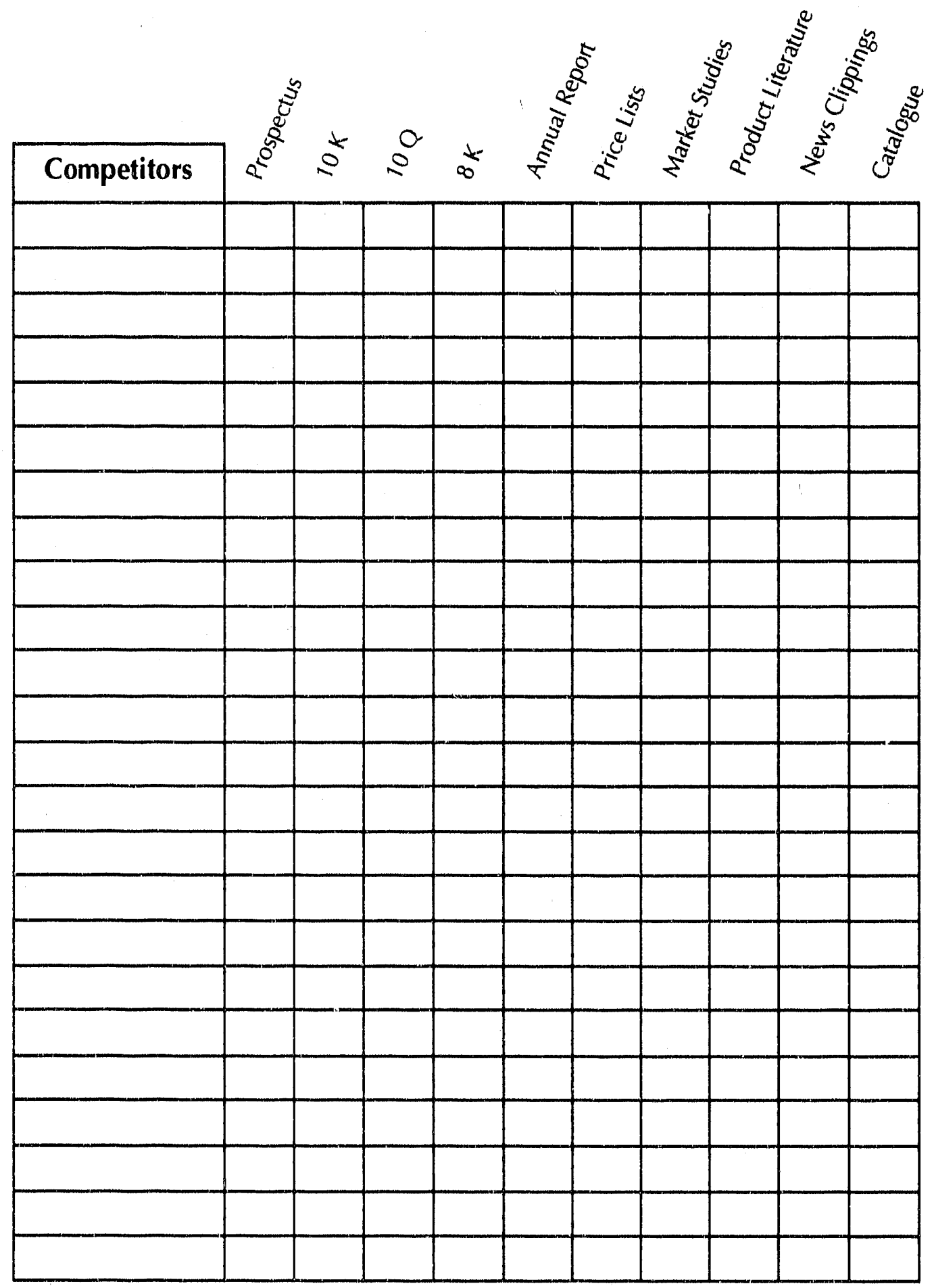




\section{WHO ELSE IS EXPECTED TO ENTER THIS MARKET?}

\section{Type of question}

\section{Variable: Competitors}

Section of Plan: Competition

\section{Why is this important?}

The world is a big place and it is possible that other companies, both large and small, might be planning to enter this market. It is good to anticipate who is likely to be entering the arena so that you can adequately plan your market penetration strategies, activities and background.

One way to anticipate who might be entering the market is to look at patents. Although this may sound like a prodigious undertaking, there are ways in which this process can be simplified.. In every state there are patent depository libraries which contain various types of information. Many of them have a CASSIS CD-ROM system available for free to the public which enables one to search the patent data for the past 17 years. The laser discs can also be purchased directly from the Patent and Trademark Office for approximately $\$ 350$.

If you know the class and subclass into which your technology falls, you can search this system to obtain information on other patents recently issued within the same class. Some of the systerns also enable you to determine to whom the patents have been assigned and/ or allow you to perform a patent search by company name. This type of searching can also be accomplished on Dialog. However, it is expensive to use Dialog for this application, unless you are a highly skilled searcher.

\section{Have I answered this question adequately?}

Process: For the time being you will have answered this question adequately if you spend some time assessing your process for determining who is likely to enter this arena and generate a list containing at least three company names, referencing the data source.

Results: Describe the approach that you typically use to determine who else might be entering this field. If you don't have an approach; feel free to indicate that. Also, provide the list of other companies who you think might enter this field. 


\section{WHAT REGULATORY AGENCIES HAVE AN IMPACT ON THIS INDUSTRY?}

\section{Type of question}

Variable: Environment

Section of Plan: Environment

Why is this important?

So often, market conditions are affected by economic factors and policies of which the new entrepreneur is unaware. The purpose of this question is to force you to look at the broader environment in which your business operates. This will help you begin to develop an understanding of the conditions which may affect market need either positively or negatively.

\section{Activities and background}

Both Federal and state legislation may have an impact on the market for your technology/ products. Find out about legislation which may affect your market by contacting the Federal or State agencies described below.

Federal: Prior to acting upon proposed legislation, Congress holds hearings, calling upon the advice of experts before making their decisions. Numerous standing committees associated with the House of Representatives are involved with the preparation of such information. These committees include Agriculture, Energy and Commerce, and Transportation. To find out if there are any bills pending on your topic, you can call Washington Legislative Information at 202-225-1772. They will advise you which Committee is sponsoring the bill.

State: Every state has regulatory agencies which determine the manner in which Federal legislation will be implemented in their state.

\section{Have I answered this question adequately?}

Process: For the time being you will have addressed this question adequately if you have identified at least one regulatory agency for each potential application.

Results: List the regulatory agencies which have an impact on your technology, either pro or con. List the agencies for each application. 
TABLE 22: Regulatory agencies

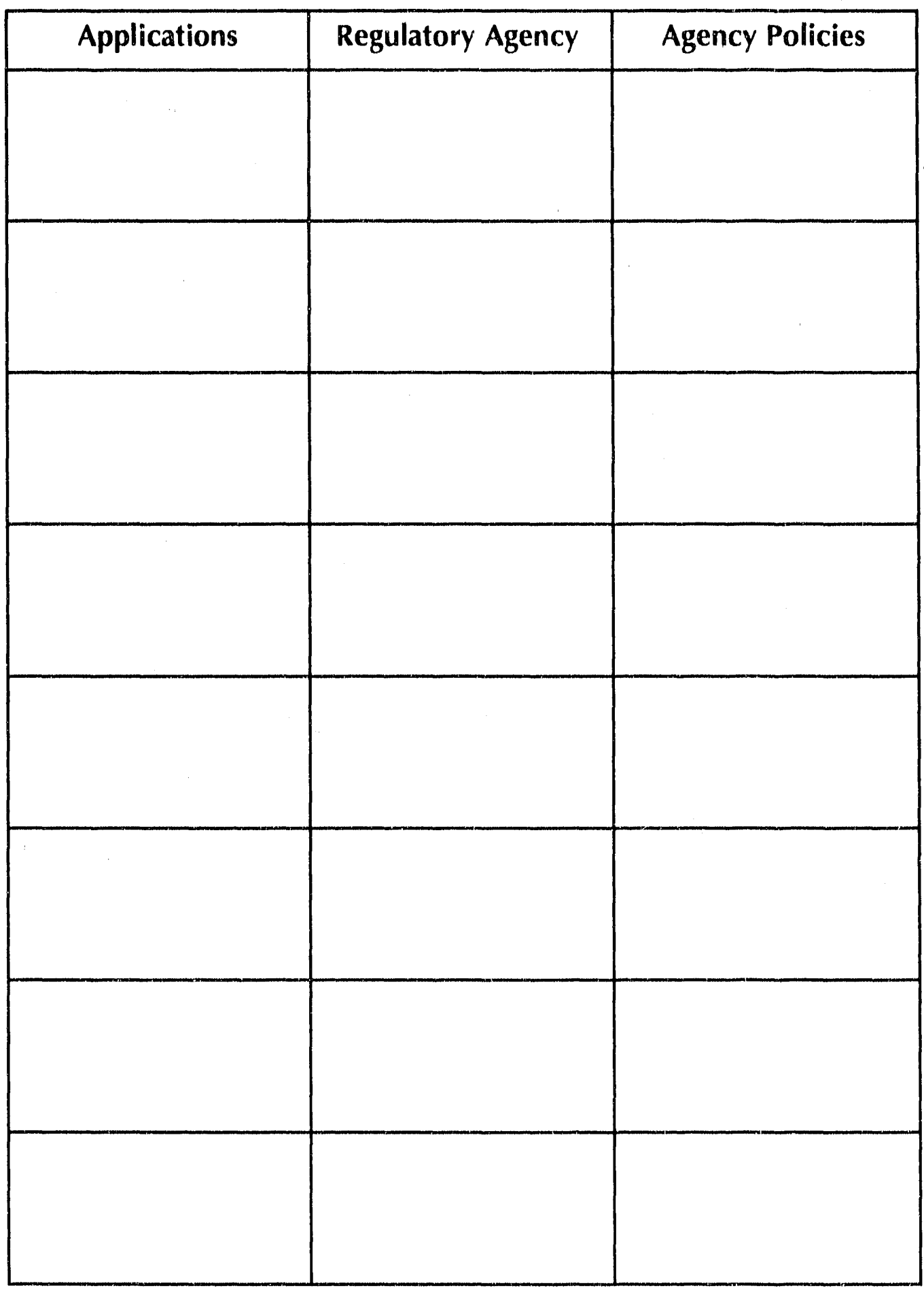




\section{WHAT IS YOUR COMPANY'S SALES HISTORY FOR YOUR TECHNOLOGY/ PRODUCT?}

\section{Type of question}

Variable: Sales

Section of Plan: Projected Income Statement

\section{Why is this important?}

Your sales history provides an index of market need. It is recognized that many of you may not yet have customers for your technology or product, given its phase in development. In response to this question, do not include SBIR grant monies as a sale - that should be considered as a funding source for $R \& D$.

\section{Activities and background}

Begin by defining what it is that your company sells, i.e. list specific products and/or services. Next to each item indicate who is responsible for selling the product or service. The "who" becomes your distribution channel. The distribution channel is direct if it involves an employee of your company and indirect if another entity distributes your product/service for a percentage. With your products and services so defined, develop a sales forecast for 1991/1992 for each product/service.

State any key assumptions that went into your forecast. Also include a list of target customers through 1992 and the potential business from each. You can test the reasonableness of sales for each distribution channel, by showing a sales per head count ratio. For example, if sales are made only by the President of your company you have a direct sales force of $1 / 2$ person (assuming that $50 \%$ of his or her time is spent in sales). If your sales projections are $\$ 1$ million in 1991, ask yourself if it is reasonable to assume that one person spending half his time can generate that much business. What is the standard for your industry? What is the track record for your company president when it comes to sales closures?

\section{Have I answered this question adequately?}

Process: For the time being, you will have answered the question adequately when you have taken your first pass at pulling these data together. You may be able to find benchmarks to determine reasonableness of your assumptions by seeing if your local business newspaper, in combination with the Chamber of Commerce produces a Book of Lists. Many cities have these. They contain many lists that are useful for benchmarking. For example, the Rochester Book of Lists has a listing of women ownea businesses. The list indicates the top 20 women-owned firms, indicating the year founded, the number of employees, and the size of revenue stream. Using this as a benchmark, one could benchmark a reasonable rate of growth and required dollar sales per person.

Results: Submit a listing of your companies products/services; sales force; customers and projected sales; sales per head count ratio for 1991/1992 by quarter. Also, include key assumptions. 


\section{WHAT IS THE DEVELOPMENT TIMELINE FOR YOUR TECHNOLOGY(IES) WITH CRITICAL MILESTONES INDICATED?}

Special Note: If you are working on new product development, please complete the chart entitled New Product Development and release activities at the end of this section.

\section{Type of question}

Variable: Sales

Section of Plan: R \& D, Projected Income Statement

Why is this important?

You can't begin to realistically calculate your company's financial requirements until you have developed a development timeline for your technology/product. If you are a larger company, obviously you would have such a timeline for each program that you are conducting.

\section{Activities and background}

Develop a technology development plan for each technology that your firm is developing. Be sure to include an indication of

- the experimental questions that need to be addressed,

- the customer specification to which this relates,

- the amount of time required to conduct each element of the R \& D.

\section{Have I answered this question adequately?}

Process: Although we are still walking you through a consideration of multiple applications, for the time being, you will have addressed this question adequately if you have developed a technology development plan which represents your current direction. It is understood that this direction might be modified.

Results: Develop a Gantt or PERT chart to represent the technology development plan for each technology/application that is under consideration. Complete the New Product Development and Release Activity if you are working on new product development. 
TABLE 23: New product development and release activities

PHASE

MGMT

\author{
AC'TIVITY
}

\# DESCRIPTION
RESPONSIBILITY

ENG MFG MAT'L MKT'G

$\begin{array}{ll}\text { Prototype } & 12 \text { Design layout complete } \\ 13 & \text { Prelim prints complete } \\ 14 & \text { Ascertain ass'y configuration } \\ 15 & \text { ID long lead items } \\ 16 & \text { All parts received } \\ 17 & \text { Prototype complete } \\ 18 & \text { Debugging complete } \\ 19 & \text { Perf. testing complete } \\ 20 & \text { Design review complete } \\ 21 & \text { Prelim P/L complete } \\ 22 & \text { Prelim. sales, quality services } \\ & \text { \& operators, manuals, and } \\ & \text { specifications complete } \\ 23 & \text { Prelim. costing complete } \\ 24 & \text { Ass'y \& test proc. complete } \\ 25 & \text { Product review complete } \\ 26 & \text { Quantities determined } \\ 27 & \text { Flow chart complete }\end{array}$

Preproduction
28 Add design changes

29 Release (ECO) part prints

30 Start weekly meetings

31 Generate routings (parts)

32 Generate W/O's (parts)

33 Obtain quotes (parts)

34 Generate PO's (parts)

35 Release (ECO) assembly prints and parts lists

36 ID long lead items

37 Assembly routings, WO's

38 Oblain quotes (ass'y's)

39 Generate PO's (ass'y's)

40) Release (ECO) assembly, test procedures 
41 Build ass'y. Test fixtures

42 All parts received

43 Complete ass'y build

44 Complete ass'y test

45 Complete burn-in and test

46 Complete ECR input to eng.

47 ECO all changes

48 Final costing complete

49 Review, final prod release

50 Schedule full production run

$0=$ Primary Responsibility

$\mathrm{x}=$ Secondary Responsibility (required) 


\section{WHAT KIND OF MANUFACTUIRING DOES THE COMPANY PERFORM? What are the major operations and their sequence?}

Special Note: Consider this question even if you do not plan to manufacture yourseif.

\section{Type of question}

Variable: Manufacturing

Section of Plan: Product/Technology or Manufacturing

\section{Why is this important?}

An understanding of the manufacturing process and the costs associated with each major operation is fundamental to projecting one's financial needs. It also points the way to opportunities for increased efficiency and cost reduction. Both of these have profound implications for profit margins.

Even if you do not intend to manufacture yourself, this question should be addressed. If you are an $R$ \& $D$ firm and fail to consider the manufacturing costs associated with what you are creating, you may find yourself without a market as the product would be too expensive for a manufacturer to produce profitably. Considering the manufacturing costs early in the product development cycle will allow you sufficient time to modify the design to enhance the ability to manufacture the product.

\section{Activities and background}

$R \& D$ firms: Contact various vendors to determine the costs associated with production of your product. Ask them to give you a quote indicating which elements or processes are most expensive.

Manufacturing firms: Provide a description of the various steps involved with the manufacturing process of each product, indicating which steps are most time consuming and costly.

\section{Have I answered this question adequately?}

Process: For the time being, you will have answered this question adequately if you contact a series of suppliers and ask them to give you a quote on the cost of manufacturing the item ( $R \& D$ firm) or work up the steps and associated costs if you are a manufacturing firm. Please consider manufacturing costs associated with

- prototyping

- pre-production quantities

- production quantities

Results: Provide a description of the various steps involved in the manufacturing process, indicating associated costs. 


\section{WHAT ARE YOUR COMPANY'S FINANCIAL REQUIREMENTS?}

\section{Type of question}

Variable: Financial

Section of Plan: Projected Income Statement, Resources

\section{Why is this important?}

On the surface, the answer to this question seems obvious - you need to know the financial requirements of your company so that you can determine how much capital you need to operate your business profitably and how you intend to raise the required funds. What is less obvious, is the manner in which to accurately calculate your financial requirements.

Very few companies are started by people with a financial background; companies instead tend to be started by people with marketing, sales, manufacturing, and scientific backgrounds. Very few companies are started by financial wizards. It appears that the frame of reference needed to assess financial need is usually quite foreign to most entrepreneurs. Lacking the right tools to determine financial requirements, the tendency is to use other approaches including "pulling a number out of thin air; providing an unrealistic number which reflects the cash available to you, rather than the cash you need; or by simply ignoring the question." However, these approaches obviously can't prevail.

As the entrepreneur becomes more sophisticated, he or she learns that various financial ratios are important. They shift to plugging numbers into a model and then grinding them out. This too is an unacceptable approach, as it does not reflect a true understanding of the costs associated with your particular business. The manner in which you should determine your company's financial requirements is to build a model based on an understanding of:

- the tasks to be accomplished by function and project ( $R \& D$, Engineering, Manufacturing, Marketing, Sales, Customer Service) ;

- the time associated with these functions and projects;

- the cost of skilled labor; and

- other operating expenses

In addition, the model should also reflect an understanding of your organization's sales, the amount of time it takes to make the sale, the cost associated with selling, the number of sales per individual in your sales force. Many R \& D firms don't consider themselves to have a sales staff. However, someone in your organization is closing the deals that are required to keep your organization going. For example, if the organization is small, it is likely that the company president will be the one responsible for selling. The form that selling might take could include developing personal relationships with colleagues at conferences, trade shows, and other trips or by visiting representatives from organizations which provide grants.

\section{Activities and background}

Developing an answer to this question will be addressed over the next three chapters and will include developing an:

Income Statement

Balance Sheet

Cash Flow and Key Measures

Expense Budget

Capital Budget 
You should anticipate that these numbers will be reworked several times. As you gather more information about the market, about customer specifications, as well as additional $\mathbf{R}$ \& D results you may find that your initial plan has to be re-evaluated with its concomitant financial implications. See Appendix $C$ for assistance with financials.

\section{Have I answered this question adequately?}

Process: Modify Table 24 to meet your circumstances and begin to calculate or review the numbers for each of the suggested line items. Presently in your organization, you may typically have this function performed by your accountant or CFO. If this is the case, we encourage you to review the expense budget in detail, questioning how all numbers were derived.

Results: For the time being, you will have addressed this adequately if you have produced an expense budget that accurately reflects your expenses for 1991 and projected 1992.

Begin by developing an expense budget detailing your expenses by quarter for 1991 and 1992. As companies of various sizes are participating in this program, the expense budget form is broken into detail for all functions of a larger firm. Please modify this appropriately to serve your purposes. For example, if your company has three functions; Administration, R \& D, and Sales, only calculate expenses for these.

TABLE 24: Creating an expense budget

\begin{tabular}{llllllllrr} 
& \multicolumn{3}{c}{1992} & & & & \\
Description & 19 & $2 Q$ & $3 Q$ & $4 Q$ & $1 Q$ & $2 Q$ & $3 Q$ & $4 Q$
\end{tabular}

Administration: (General Mgt., Finance, and Human Resources)

Head count

Sq. ft. of space required

Compensation: salaries benefits

Business exp: meals \& entertainment room travel

Phone exp

Supplies

Training

Autos

Outside services

Depreciation exp.

Misc. 
Description

\section{$1 Q$}

$2 Q$

30

$4 Q$

10

$2 Q$

$3 Q$

$4 Q$

Engineering

Head count

$\mathrm{Sq}$. $\mathrm{ft}$. of space required

Compensation: salaries benefits

Business exp: meals \& entertainment room travel

Phone exp

Supplies

Training

Autos

Tools under $\$ 1,000$

Material purchases

Outside services

Depreciation exp.

Misc.

1991

Description

Marketing \& Sales

Head count

Sq. ft. of space required

Compensation:

salaries

benefits

Business exp:

meals \& entertainment

room

travel

Manufacturer's rep comissions

Phone exp

Supplies

Training

Autos

Tools under $\$ 1,000$

Material purchases

Outside services

Marketing communications:

trade shows

advertising

literature development

printing

direct mail \& postage

Depreciation exp.

Misc. 


\section{Description}

1Q $2 Q \quad 3 Q$

$4 Q$

1Q $2 Q$

1992

\section{Manufacturing}

Head count

direct

indirect

sub total head count

Sq. $\mathrm{ft}$. of space required

Compensation:

Direct

salaries

benefits

Indirect

salaries

benefits

Material purchases

Outside services

Business exp:

meals \& entertainment

room

travel

Phone exp

Supplies

Training

Tools under $\$ 1,000$

Depreciation exp.

Facility costs: (put total of business here for convenience)

rent

maintenance

heat

electric

Sub total manufacturing expense

Misc.

\section{RE-EVALUATION}

After having gathered the data in preparation of Report \#3, the project leader should convene a meeting of the management team. In advance of the meeting, Interim Reports 1,2 , and 3 should be provided to everyone to read.

The purpose of the meeting will be to discuss if any of the data surfaced to date has an impact on elements of the Mind Map (Interim Report \#1) or the Vision Statement prepared in Interim Report \#2. In other words, do the data collected to date tend to substantiate or refute elements of your mind map and/or Vision? Use the following work sheet to indicate where there is agreement or conflict and also indicate any new action items that are implied by the data considered to date. 
TABLE 25: Re-evaluation worksheet

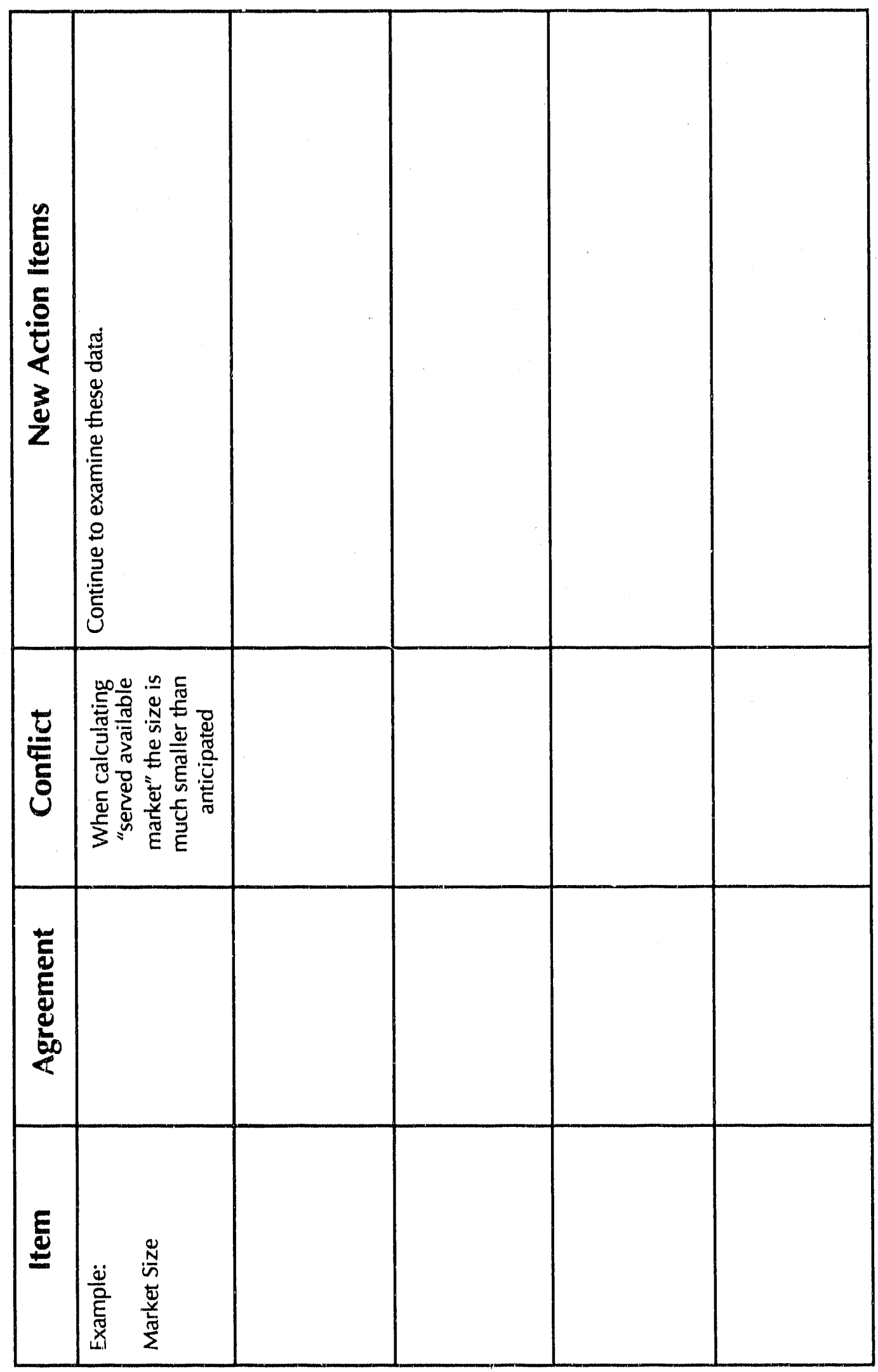




\section{CHAPTER 8: INTERIM REPORT \#4}

\section{WHERE ARE WE?}

In preceding chapters you have been asked to simultaneously consider multiple applications and markets. At this point however, you should begin focusing on particular applications and/or products. Making a decision at this time does not preclude the option of changing your mind at a later date. Conditions change and what may constitute an unwise choice today may be the best decision tomorrow. These decisions are difficult and are only yours to make. Before narrowing the range of options under consideration, you should address question \#1 in this section. Once this has been completed, your management team should begin to narrow the range of options.

The questions to be addressed in preparation of Interim Report \#4 continue to probe more deeply into your competitors, your competitive edge, and also will require greater financial analysis. As more data are gathered, the rate at which you shift from conjecture to certitude should accelerate. At the end of this chapter you will again be asked to consider if there are any additional changes to your mind map or vision, implied by the new round of data gathered.

Tasks: There are 10 tasks associated with the preparation of Interim Report \#4 . Each task consists of conducting the research needed to answer each of the questions listed in Table 26. Many of these questions are compound questions with related sub-parts. 
TABLE 26: Project planning for Interim Report \#4

\begin{tabular}{|c|c|c|c|c|c|c|c|c|c|c|}
\hline 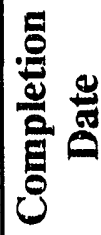 & & & & & & & & & & \\
\hline 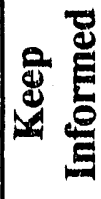 & & & & & & & & & & \\
\hline$\frac{8}{8}$ & & & & & & & & & & \\
\hline 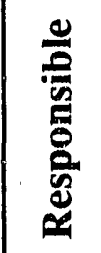 & & & & & & & & & & \\
\hline 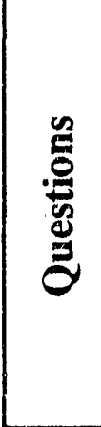 & 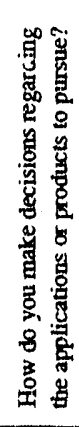 & 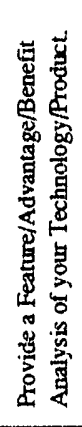 & 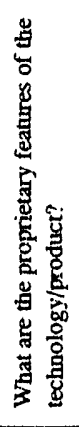 & 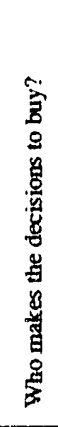 & 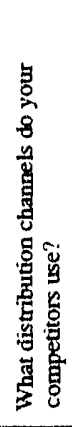 & 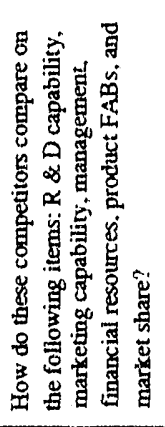 & 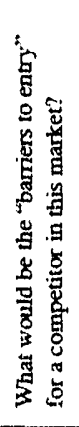 & 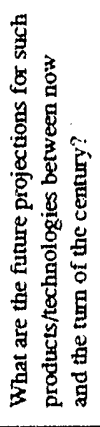 & 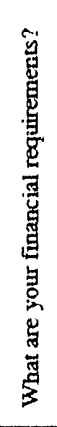 & 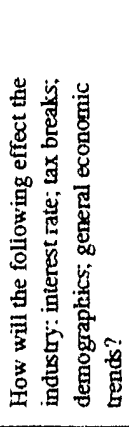 \\
\hline
\end{tabular}

Time: You will need to allocate time to conduct the research required in order to answer each of these questions. The tasks involved in completing Interim Report \#4 require data gathering, number-crunching, decision-making and re-evaluation. Once your data gathering needs are clarified, these activities could be carricd out with the assistance of others: a consultant, graduate student, SBDC, SCORE, a staff person. However, it is important to clarify the form in which you will need the information so that you may assimilate it as quickly as possible. You will need to use these data in Chapter 9 to develop various strategies. Be certain that the people involved with data gathering understand your deadlines. 
TABLE 27: Cognitive skills required in preparation of each interim report

\begin{tabular}{|c|c|c|c|c|c|}
\hline $\begin{array}{l}\text { Cognitive } \\
\text { Skills }\end{array}$ & $\begin{array}{l}\text { Mind } \\
\text { Map }\end{array}$ & Report 2 & Report 3 & Report 4 & $\begin{array}{c}\text { Business } \\
\text { Plan }\end{array}$ \\
\hline data gathering & & $x$ & $x$ & & \\
\hline $\begin{array}{l}\text { number } \\
\text { crunching }\end{array}$ & & & $x$ & $x$ & $x$ \\
\hline $\begin{array}{c}\text { business plan } \\
\text { writing }\end{array}$ & & & & & $x$ \\
\hline review & $x$ & $x$ & $x$ & $x$ & $x$ \\
\hline decision making & $x$ & $x$ & & $x$ & $x$ \\
\hline strategizing & $x$ & $x$ & & $x$ & $x$ \\
\hline re-evaluation & $x$ & $x$ & $x$ & $x$ & $\mathrm{x}$ \\
\hline
\end{tabular}

Report format: In organizing Interim Report \#4, it is suggested that each question be addressed on a separate page(s). The top of the page should contain the following

- the question

- the variable to which this question is related

- the name of the section of the business plan to which it is related

- the names of the people involved with gathering the information

- the date

Be sure to also include the re-evaluation and your response to Dawnbreaker's feedback. 


\section{HOW DO YOU MAKE DECISIONS REGARDING THE APPLICATIONS OR PRODUCTS TO PURSUE? \\ What type of market data is collected before proceeding with R \& D? \\ What customer specifications become part of $R \& D$ plans?}

\section{Type of question}

Variable: Market

Section of Plan: Market

\section{Why is this important?}

Organizations have limited resources and need to make their decisions wisely regarding their application. In Chapter 6 you were asked to take stock of the manner in which your company makes decisions regarding $\mathrm{R} \& \mathrm{D}$ and to recommend ways in which to improve your track record.

\section{Activities and background}

Hopefully, by this point you have read Cooper's book entitled New Product Development and have considered making modifications to the process you presently apply, if your existing process has not been very successful.

\section{Have I answered this question adequately?}

Process: You will have answered this question adequately when you have thoroughly analyzed the process that your company has historically used to select $R \& D$ projects, reflecting upon your success in selecting projects that have led to the development of applications with high commercial probability.

Results: If you have made a modification to the process, please describe the process that your organization uses. Indicate what type of market data are routinely gathered to help make these decisions and how customer specifications become a part of this process in the early stages. 


\section{WHAT ARE THE FEATURES/ADVANTAGES/BENEFITS OF YOUR TECHNOLOGY/ PRODUCT AS COMPARED TO THAT OF YOUR COMPETITORS?}

\section{Type of question}

Variable: Market

Section of Plan: Market, Competition, Product

\section{Why is this important?}

Customers use different criteria in making their purchasing decisions. Sometimes the decision is based on price and at other times on the features, advantages, and benefits of the product. It is therefore, important to know how your technology/product compares to competitive products and services that are available.

\section{Activities and background}

At this point you should have gathered considerable data on your competitors, including price sheets, product and technology descriptions, catalogs, and market research. With these data in hand, you can now proceed with conducting a FAB anaiysis of your technology/product as compared to that of your competitors.

A Feature is an element or property of the product or technology.

An Advantage answers the question "So What?" and indicates the value of this feature. The advantage is frequently described in technical terms and tends to describe the company's perspective.

A Benefit describes the value to the end user as he or she would perceive it.

\section{Have I answered this question adequately?}

Process: You will have addressed this adequately when you are able to complete the FAB matrix for your company and three others, listing at least five features for each technology/product. There should be a corresponding advantage and benefit for each feature.

Results: Complete the FAB analysis sheet in Table 29 for your technology/product, as weil as that of your three primary competitors. 
TABLE 28: Feature, Advantage, Benefit (FAB) Analysis

\begin{tabular}{|c|c|c|}
\hline Features & Advantage & Benefit \\
\hline $\begin{array}{c}\text { Example: } \\
\text { Sleeve bearing }\end{array}$ & long lubricating life & less down time \\
\hline & & \\
\hline & & \\
& & \\
\hline & & \\
\hline & & \\
\hline
\end{tabular}


WHAT ARE THE PROPRIETARY FEATURES OF THE TECHNOLOGY/PRODUCT?

How important is the intellectual property position to the success of the business?

Type of question

Variable: Product

Section of Plan: Strategies and Tactics

Why is this important?

Intellectual property is valuable and transferable. It allows the person entitled to the intellectual property to exclude others from manufacturing the item or using the process in the country in which the patent is granted. In recent years, courts have been more sympathetic to scientists/inventors, upholding their claims more readily in infringement suits.

\section{Activities and background}

Check with your legal counsel on the status of your intellectual property. Be sure that you are following correct procedures to safeguard your irtellectual property. Many times scientists assume that they are doing things correctly and they may be in error.

\section{Have I answered this question adequately?}

Process: You will have answered this question adequately if you:

- checked to assure that your maintenance fees have been paid on outstanding patents,

- checked to see to determine the status of any new patent applications subrnitted to the Patent and Trademark Office,

- checked with an attomey to ensure that you are following correct procedures if you wish to protect your technology via trade secrets,

- checked to see if copyrights have been registered with the Library of Congress which is the best way to protect yourself against infringement with copyrighted material,

- checked to see that you are following correct procedures with trademarks that you may have.

Results: Indicate what procedures you are taking to protect your intellectual property and when you last checked to assure that things were in order. 


\section{WHO MAKES THE DECISIONS TO BUY? \\ How are buying decisions made? \\ How long does it take for such decisions to be made? \\ What affects their buying decision?}

\section{Type of question}

Variable: Market

Section of Plan: Market

Why is this important?

Your company's cash flow depends upon your potential customers' buying behavior. It is very common for new organizations to give inappropriate consideration to the sell cycle of potential customers and how their buying decisions are made. However, one quickly learns that adequate cash tlow is what keeps a company going. Cash flow is dependent upon your customers.

\section{Activities and background}

In Chapter 6 you identified the potential customers for the various applications under consideration. With respect to the application(s) or product(s) that you have decided to pursue, list the customers and what you know about their buying behavior.

\section{Have I answered this question adequately?}

Process: You will have answered this question adequately when you have good solid data regarding each potential customer. For example, Company X makes decisions by committee. However, the process begins with a meeting with the Mr. John Doe who acts as the first level screen. Mr. Doe is very hard to reach by phone or in person, thus it takes about a month to set up an initial meeting. The committee meets every two weeks, but it takes about two months for new ltems to appear on their docket. Once the decision is made to buy, processing the paper work takes approximately another two months. Their decision to buy is very much affected by referrals, the state of the art and your prestige. After you begin working for Company $X$, their payments are made within 90 to 120 days, even though terms are indicated as 30 days. This information was gathered through a conversation with another vendor who has worked with this company for over 5 years.

Results: Make a list of the customers (at least at the company level). Indicate who makes the decisions, how long the sell cycle takes, and what types of considerations affect their decision to buy. Indicate your data source for each item. 
TABLE 29: Buyer Behavior

\begin{tabular}{|c|c|c|c|c|}
\hline Customer & $\begin{array}{c}\text { Where } \\
\text { decisions made }\end{array}$ & Sell cycle & Considerations & Data Source \\
\hline & & & & \\
\hline & & & & \\
\hline & & & & \\
\hline & & & & \\
\hline & & & & \\
\hline & & & & \\
\hline & & & & \\
\hline & & & & \\
\hline
\end{tabular}


WHAT DISTRIBUTION CHANNELS DO YOUR COMPETITORS USE?

What distribution channels do your customers use?

How does the distributor's compensation oil company products compare with its

compensation on other products it distributes?

What other products does the distributor carry?

\section{Type of question}

Variable: Sales

Section of Plan: Market, Strategles and Tactics, Contingency Planning, Resources

\section{Why is this important?}

Your ability to penetrate a market quickly is in part detemined by your method of distribution. As you are reading this you may assume that you don't need to be concerned aboul distribution as your company is a research firm. However, even contract R \& D firms need to be concerned about distribution. You are after all competing with other $R$ \& D firms and other technologies. How your customers come to know about your products and services is in part a dirtribution question.

It is also important that you understand the distribution methods used by your customers, as there are costs associated with distribution which affect the price that they can pay for elements of the products they are distributing.

There are two primary means of distribution:

- direct through a sales force employed by the company (referred to as direct channel) or

- indirect, through a third party (indirect channel).

Keep in mind that small companies usually do not have a dedicated sales force, but have people who from time to time wear a sales hat. This too is a form of direct distribution.

\section{Activities and background}

Make a list of your primary competitors. Indicate the distribution channel(s) they use and how many people are involved. For example, Company $X$ has three primary competitors: TechnoBrain, Entech, and $X Y Z Z$ Technologies. TechnoBrain has a Vice President of sales and employs 5 people in a sales department. The sales staff calls potential customers and conducts the prospecting. Visits to hot prospects are made by teams consisting of an engineer and a member of the sales staff.

Follow the same procedure for your top three customers, These data may be more difficult to obtain. One can start by contacting manufacturer's representatives to obtain information about customers. A useful resource to consult in this regard is the

\section{Directory of Manulaclurer's Sales Agencies}

Published by Manufacturers' Agents National Association

Laguna Hills, CA

Phone:714-859-4040

In the 1991 edition you will find six pages of entries under the descriptor "Energy" and an equal number under "Gas, Oil, and Petroleum Products and Services." Each two-line entry lists the manufacturer's sales agency and address.

The type ol data you would like to obtain is an indication of the number of direct sales people and manufacturer's representatives your customers have. You can also make inquiries of manufacturer's reps regarding customer reaction to products, margin:. and the like. 
Have I answered this question adequately?

Process: Examine the Directory of Manufacturer's Sales Agencies and begin to contact some manufacturer's reps to learn more about your potential customer's distribution means.

Results: Make a list of your primary competitors. Indicate the distribution channel they use and how many people are involved. Follow the same procedure for your top threc customers.

TABLE 30: Distribution channels for your competitors and customers

\begin{tabular}{|l|l|l|}
\hline Distribution Channel & $\begin{array}{c}\text { Competitor or } \\
\text { Customer }\end{array}$ & Source \\
\hline & & \\
\hline & & \\
\hline & & \\
\hline & & \\
\hline
\end{tabular}


HOW DO THESE COMPETITORS COMPARE ON THE FOLLOWING ITEMS: R \& D CAPABILITY, MARKETING CAPABILITY, MANAGEMENT, FINANCIAL RESOURCES, AND MARKET SHARE?

\section{Type of question}

Variable: Competitors

Section of Plan: Strategies and Tactics, Contingency Planning, Risk

Why is this important?

As mentioned in other chapters, what your competitors do is always important, as you are competing for dollars which are vital for survival. When developing strategies and tactics, this must be done keeping in mind the nature of your competitor. Thus, knowing as much as you possibly can about your competitor can help you prepare your strategies.

\section{Activities and background}

Finding answers to these questions is difficult and will involve talking to customers, suppliers, and investors. This type of information is often gathered informally at trade shows, conventions, and other meetings. Talk to other members of your staff and see what type of information they may have regarding your competitors. In addition, go back and review the data you have been collecting in the competitor files over the past several weeks. Be sure to study carefully the materials obtained from the SEC.

\section{Have I answered this question adequately?}

Process: You will have answered this question adequately when you have sufficient data about your competitor to enable you to begin to think objectively about how your resources compare to those of your competitors. Make a list comparing your company and your competitors with respect to $\mathrm{R} \& \mathrm{D}$ capability, marketing capability, management, financial resources, and market share.

Results: Provide a list of the types of information that you have regarding your competitors with respect to these questions. You should already have files set up on your competitors from previous research that you have done. 


\section{WHAT WOULD BE THE "BARRIERS TO ENTRY" FOR A COMPETITOR IN THIS MARKET?}

\section{Type of question}

Variable: Competitor

Section of Plan: Strategies and Tactics, Projected Income Statement, Contingency Planning

\section{Why is this important?}

A potential investor will be concerned about how even the playing field is. In other words, what is the likelihood that a new player may enter the picture, posing a threat. One way to assess this is to look at how much it would cost to get into this business.

\section{Activities and background}

The phrase 'barriers to entry' refers to how easy or difficult it would be for a competitor to get started in your business. Types of things to consider are

- intellectual property,

- sunk costs, and

- unique technical skills

\section{Have I answered this question adequately?}

Process: Examine the intellectual property, sunk costs, and unique technical skills of your staff. Consider how difficult or easy it would be for a competitor to match you in these areas. Who is likely to try doing this? How will you respond if they enter the market?

Results: Provide a written description of your unique technical skills, sunk costs, and intellectual property. Indicate which of your competitors are most capable of developing a similar product or technology. 


\section{WHAT ARE THE FUTURE PROJECTIONS FOR SUCH PRODUCTS/TECHNOLOGIES BETWEEN NOW AND THE TURN OF THE CENTURY?}

\section{Type of question}

Variable: Product

Section of Plan: Contingency Planning

\section{Why is this important?}

If another, less expensive, easier to use technology or product comes along, it is likely to put you out of business. You therefore need to keep abreast of what is going on in the market place so that you can prepare and adjust for this eventuality. You don't want to be blind-sided.

\section{Activities and background}

Make a list of competing technologies, indicating the major technical obstacles that each must address. Assign a probability to the likelihood that there will be success in addressing these obstacles within the next 10 years. Give a clear reason why you feel that the obstacle can or can't be overcome.

\section{Have I answered this question adequately?}

Process: You will have addressed this question adequately if after searching the literature you are able to complete the following Table.

Results: Using Table 31 as your guide, list your technology and competing technologies in the first column. In adjacent columns indicate both the obstacles that need to be overcome before the technology is commercially viable and the key data sources that were consulted in assessing the obstacles. In the last column, assign a probability to reflect your assessment of the likelihood of successfully overcoming those obstacles within the rext five years. 
TABLE 31: Competing Technology Analysis

\begin{tabular}{|l|l|l|l|}
\hline Technologies & Obstacles & Data Source & $\begin{array}{c}5 \text { Year Success } \\
\text { Probability }\end{array}$ \\
\hline & & & \\
& & & \\
\hline & & & \\
\hline & & & \\
\hline & & & \\
\hline
\end{tabular}




\section{WHAT ARE YOUR FINANCIAL REQUIREMENTS?}

\section{Type of question}

Variable: Finance

Section of Plan: Projected Income Statement

Why is this important?

See Chapter 7.

\section{Activitles and background}

In the previous chapter you began to chart your income and expenses for 1991 and 1992 by quarter. Those projections were based on how you were conducting business at that time. Now that you have re-evaluated the applications and products you will develop, review the financials to determine if the numbers you generated previously reflect your modified direction. If not, modify your financials appropriately. Project through 1992 by quarter and then annually through 1995.

Re-visit your goals articulated in your vision statement. In light of what you now know about your competitors, re-evaluate your goals and/or your requirements to successfully compete in the market niche of choice. Once this has been done, examine the financials again and modify them appropriately.

You will now need to begin developing an income staternent, a balance sheet, and a cashflow statement. Rather than describing this process here, one is referred to the appendix of Raising Venture Capital by Deloitte, Haskins, and Sells. Another useful resource to consult in building your financials is Anatomy of a Business. Plan by L. Pinson and J. Jinnett, published in Fullerton, CA by "Out of Your Mind...and Into the Marketplace" Phone: 714-544-0248.

\section{Have I answered this question adequately?}

Process: Read the recommended sources and continue to develop your financials from the bottom-up.

Results: Develop your Balance Sheet, Cash Flow, and Key Measures and Assumptions in the fashion outlined in the Deloitte, Haskins, and Sells resource. 


\section{HOW WILL VIS FOLLOWING AFFECT THE INDUSTRY \\ interest rate \\ tax benefits \\ demographics \\ general economic trends?}

Type of question

Variable: Environment

Section of Plan: Environmental Analysis, Contingencies

Why is this important?

General economic trends do have an impact on companies' potential for growth. Frequently, the factors listeci above are overlooked, as they seem so remote from the business at hand.

\section{Activities \& Background}

Gather information by examining issues of Financial World, Money, Fortune and other trade journals associated with economic conditions. Speak with the authors of pertinent articles in the Industrial Outlook produced by the Department of Commerce. Ask everyone with whom you speak to recommend other sources for finding relevant information.

\section{Have I answered this question adequately?}

Process: You will have answered this question adequately when you have spent several hours looking for information in the recommended sources.

Results: In narrative form, describe the data you have found regarding changes in the economic environment which are likely to affect your industry. 


\section{RE,EVALUATION}

After having gathered the data in preparation of Report \#4, the project leader should convene a meeting of the management team. The purpose of the meeting will be to discuss if any of the data surfaced in preparation of Interim Report $\# 4$ has an impact on clements of the Mind Map or the Vision Statement. Use Table 32 to record areas of agreement or conflict, as well as new action items that are implied by the data. 
TABLE 32: Re-evaluation worksheet

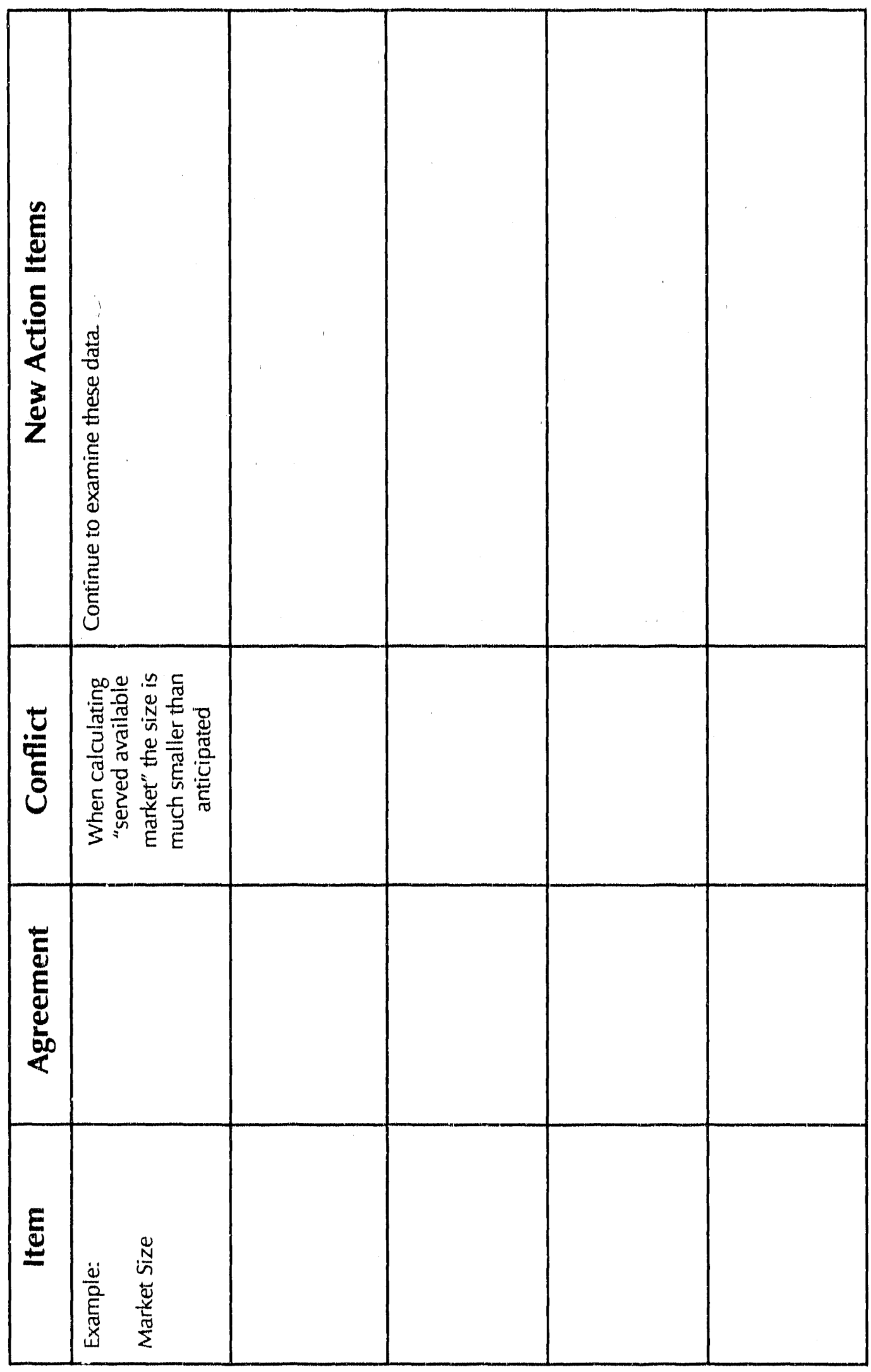




\section{CHAPTER 9: PUTTING IT ALL. TOGETHER}

\section{WHERE ARE WE?}

Duting the past several weeks you have spent considerable the gathering data and reflecting upon their implications for your business. The re-evaluation activities at the end of chapters 7 and 8 were designed to assist you in Integrating these data and in considering their implications for your business. The purpose of this chapter is to

- Assist you in strategy development.

\section{PREPARING FOR STRATEGY DEVELOPMENT}

When you reach this point in the planning process, you will have collected all the data necessary lo complete secilons I-VII of the business plan (See p. 41). What you will be doing during the strategy sessions is deciding what infurmation to enter into Sections VIII - XV of the business plan. Although Sections XIII and XV have been completed in Chapter 9, it is llkely that the linancials will need to be modified as a result of your stralegy sessions. Make sure that the person who is assisting you with the financlals is available to modify them during this session. You will also need this person's assistance in compiling historical data.

In lackling this last aspect of business planning, you will need blocks of uninterrupted time. Companles have different ways of weaving this lime into their busy schedule. Some management teams prefer to tackle this over long weekends. Participants become totally involved in the process for a couple of days and put everything else on hold. Other companles set aside time each evening for a week. Whatever method you use, the time spent in this part of the process should be intense. This is absolutely imperative as it cnables participants to remain mindful of all the variables under consideration.

Some management teams set up a 'command center' for their strategy sessions, lining the walls with large or small sheets of paper containing key inlormation (Sce Figure 12). This is the approach that we prefer, as it enables all members of the team to have access to all the data throughout this entire process. Additionally, with all key data lining the walls, it's easier to assure that every element is addressed in the business plan.

If you try this approach, we would tecommend that the headings that you use to group the data relate to each of the sections of the business plan as described on page 41. You will also need an easel with flip charts, markers, and masking tape so that you are prepared to capture people's concerns and suggestions.

As you have no doubt discovered, all elements of your business interrelate. Changes in one section lead to a modification in others. In this section you must concurrently consider your:

- markeling/salles

- R\&D

- cngineering

- manufacturing

- human resource

- linancial

strategies or methods of realizing your goals and objectives.

As this is a closed system, modifications in one section will lead to modifications in others. As this aspect of the planning process tends to be more of an art, we recommend 
that you refrain from making decisions in this procoss too oarly. Entertaln various options In your strategy session and work. them through to declde which option looks best.

We are golng to approach this section as if one of our stalf members was lacilltating your' strategle planning sessions. Please work through these matorlals in the order rocommended:

\section{SETTING THE STAGE}

All members of your management team should participate in this session. If you are the sole proprietor and do not have a managenent team, it is important that you sclect a trusted person to spar with you. As it is too easy to assume an unusually rosy perspectlve, It is vital to have other perspectlves on the strategles that you intend to follow. Be sure to incorporate Dawnbreaker's feedback as part of the perspectlve to be considered,

\section{MATERIALS}

Every participant should have copies of all Interim Reports, Dawnbreaker's feedback, and access to all primary source data. Please ask your finance person to prepare the following financial information for the meeting.

\section{Key Customer Sales Analysis' (historical)}

Provide an historical 5 year comparative summary of your litm's sales by customer or customer segment (See Table 33), Provlde separate categories for SBIR monies, Government contracts (non-SBIR), and commerclal sales, broken out by customer.

\section{Technology/Product Sales Analysis (histortcal)}

Provide a 5 year historical comparative summary of technology/product revenue sales (See Table 34). For the purpose of this analysis, include funds from commercial customers only. Please differentiate between technologies and products. Revenues can be in the form of royalties paid for licensing a technology, custom development work, and sales of widgets.

\section{Cash Flow Analysis (projected)}

Develop a projected cash flow analysis for the next live years. If you are entertaining multiple products of SBU's develop this separately for each. Be sure to Include with the cash flow analysis a narrative description of all your forecast assumptions. 
Table 33: Key customer sales analysis (historical)

\begin{tabular}{|c|c|c|c|c|c|}
\hline Customers & 1987 & 1988 & 1989 & 1990 & 1991 \\
\hline \multicolumn{6}{|l|}{$S B \mid R$} \\
\hline \multicolumn{6}{|l|}{ DOE } \\
\hline \multicolumn{6}{|l|}{ DOD } \\
\hline \multicolumn{6}{|l|}{ NASA } \\
\hline & & & & & \\
\hline & & & & & \\
\hline \multicolumn{6}{|l|}{$\begin{array}{l}\text { Covernment } \\
\text { (non SBIR) }\end{array}$} \\
\hline & & & & & \\
\hline & & & & & \\
\hline & & & & & \\
\hline & & & & & \\
\hline & & & & & \\
\hline \multirow{2}{*}{\multicolumn{6}{|c|}{ Commerclal }} \\
\hline & & & & & \\
\hline & & & & & \\
\hline & & & & & \\
\hline & & & & & \\
\hline & & & & & \\
\hline
\end{tabular}


T'able 34: Commercial technology/prodect sules analysis (historical)

\begin{tabular}{|c|c|c|c|c|c|}
\hline \multicolumn{6}{|c|}{ Commercial Customers Only } \\
\hline Technology & 1987 & 1988 & 1989 & 1990 & 1991 \\
\hline & & & & & \\
\hline & & & & & \\
\hline & & & & & \\
\hline & & & & & \\
\hline \multirow{2}{*}{\multicolumn{6}{|c|}{ Product }} \\
\hline & & & & & \\
\hline & & & & & \\
\hline & & & & & \\
\hline & & & & & \\
\hline & & & & & \\
\hline & & & & & \\
\hline & & & & & \\
\hline \multicolumn{6}{|l|}{ Services } \\
\hline & & & & & \\
\hline & & & & & \\
\hline & & & & & \\
\hline & & & & & \\
\hline
\end{tabular}




\section{STEP 1: INTERNAI. DIAGNOSIS}

\subsection{SWOTT Analysts}

A useful starting point to begin your flist strategy session is with a SWOTT analysis. This is a listing of your company's Strengths, Weaknesses, Opportunitles, Threats, and Trends. The group should generate this Information while asseninted by making a list of ltems under each heading. Strengths and weaknesses reflect a liming current capabillites. A: this point it would be useful for participants to revlew the various analyses which the finance person has created and spend time discussing their implications. The analyses to be considered should include: Key customer sales analysis, Technology/Product revenue analysis, and Cash flow analysis. Opportunities, Threats, and Trends reflect your assessment of the future. Be sure to include competing technologies in your assessment of threats, not only those competitors working on the same technology.

\section{STEP 2: MARKET STRATEGIES}

\subsection{DEFINE THE MARKET}

Start by revlewing the market niche you have selected for your playing field. Assess whether or not you have segmented it correctly by re-examining:

- the variety of competitive suppliers, technologles, and products

- the reasons why customers buy

- customer specifications

- the feature/advantage/benefits of your technology/product and how these FABS compare to customer specifications. Are you giving them more than they want or not enough?

In looking at how you have sized the market reconsider the three criteria proposed by Taylor (See p. 83).

(1) Is the segment definable in some operational way? In other words can you quantily and pinpoint the customers and end-users?

(2) Can you reach this segment effectively through affordable advertising? Examine what are the appropriate forms of advertising and price them.

(3) Is the market small enough for you to dominate within 5 years and large enough to provide good profits?

Remember you can resize the market segments you tackle as your business grows. In other words, each year as you revise your business plan, you will examine how you are performing in the market place and how the playing field has changed. Certain changes in your performance or strategies may justify redefining the market you are in such that you bite off a larger "plece of the action" to tackle.

Let me give you an example.

"Traintech" is a start-up conpany in Billings, Montana that wishes to sell a wide assortment of training seminars to industry. They have heard that training is becoming increasingly important and wish to develop a strategy to get a piece of the action. In their preliminary market research they discovered that sales of training to industry was a 19 billion dollar market. They formulated the following mission statement:

"TrainTech is a training and consulting firm that designs and delivers unique training programs to industry." 
Traintech would have been wrong to assume that this total market of 19 billion dollars (fictitious numbers used throughout) was their playing fleld. To size the market appropriately they had to examine the different types of training providers and examine what affects the purchasing decision of potential customers. Further digging revealed that the major providers of training to industry included:

- small training firms (15\%)

- training programs associated with universities and colleges (45\%)

- training provided by major accounting fïrms (15\%)

- large training institutes (10\%)

- training franchises (15\%)

Traintech conducted further research and found that:

(1) Depeirling on the size of the company, purchasing decisions were either made by the human relationss or personnel department, or individual managers.

(2) In larger firms the sell cycle was usually 6-12 months. The persons who evaluate the products do not usually have purchasing power. Companies tend to stick with known suppliers and only make a change if they are very unhappy or if they are looking for a specialty product.

(3) The primary reasons for purchasing varied depending upon the size of the company. In large companies training is often a perk and is given to fast-trackers. These companies send their executives to Ivy League universities for their specialty training. Technical training was also preferred from university vendors. Trainers that would be imvited into a large industry tended to be the "Guru of the month" - usually an academic with a new book on the Top 10 list.

(4) Training for secretaries and lower-level employees typically went to training franchises that offered one day seminars for a $\$ 100$ fee in a local hotel. In this fashion, large corporations were able to provide no-frills training for their lower level employees without paying the expense of travel, room and board.

After gathering these data. Traintech took a long serious look at themselves. They were undercapitalized and therefore had a very limited marketing and sales budget. They had a small office; certainly not a beautiful facility where executives' would want to hold retreats. They did not have a guru of the month on board. They therefore made the following decisions, regarding their present market:

(1) They were competing against other small training firms and not against the larger providers.

(2) They also decided that they should probably look to sell their training programs to smalle'r companies, rather than large industrial firms. They didn't have the "guru of the month" to make sales to larger firms. Another option to entertain was "could they attract a guru of the month." If they could, they could then tackle a larger piece of the market.

(3) Considering the length of the sell cycle and the cost of travel, TrainTech decided to limit its market scope to its immediate geographic location, thus decreasing the costs associated with sales. They gathered as much data as they could about competition (i.e. small training firms going after the same market). They examined their competitors' sales volumes and number of employees (data were available in a Book of Lists published in conjunction with the local Chamber of Commerce). They used the competitors' sales figures and assumed a 5\% marker growth rate and thus redefined the size of their market. The size of the market in which they were competing was a $\$ 10,000,000$ market. This was 
was their served available market, that is the part of the total available market in which they were going to compete. They had a list of names of all the companies to which they would like to sell their products, as well as a list of their competitors and comparative features, advantages, and benefits.

After going through this entire process TrainTech revised its mission statement:

"TrainTech is a training and consulting firm that designs and deitvers training programs to small high tech firms in Montana."

\section{STEP 3: R\&D STRATEGY}

\section{1: Contrast your technology/product with your competitors}

Keeping in mind customer specifications, compare your technology/product with those of your competitors. Are there other featires of your technology/product which would make your product more desirable, even though it is more expensive to purchase? Are the savings greater with your product such that the initial investment cost is recouped in savings within a short period of tirne? Such things become selling points and also have implications for how you position your product in the market and how you define your market niche.

An example:

Customer X ran a successful income tax firm at which 3 of his employees each spent an average of 12 hours a week copying documents, at an average labor cost of $\$ 15 /$ hour. The salesman was able to show that the XYZ copier, running at 4 times the speed of the competing unit, would save 27 employee hours, or $\$ 405$ per week. At this rate of savings, the entire $\$ 8,000$ investment would be paid back in less than five months!

* If we amortize over the expected five year life of the equipment, and assume the cost of money is $10 \%$, then customer $X$ can expect to pay $\$ 2,100 /$ year for the $X Y Z$ copier, with an employee savings of $\$ 21,060 /$ year, realizing a yearly net savings of nearly $\$ 19,000$. Considering that the competing copier would cost $\$ 1,050 /$ year over this five year period with no employee labor savings, the quantifiable financial advantage (QFA) for purchasing the XYZ copier is slightly over $\$ 20 \mathrm{~K} /$ year or $\$ 100 \mathrm{~K}$ over five years based on speed alone. If customer $X$ translates the savings in employee labor time into direct economies, then the $\$ 20 K$ yearly savings for this small accounting firm has a direct impact on net profit.

In addition, there were qualitative advantages to using the $X Y Z$ copier, with higher resolution, color copies, increased durability, and greater office efficiency due to the virtual elimination of lines at the copier, allowing executives to copy quickly themselves.

Can you represent the savings in a similar fashion? What are the quantifiable financial advantages (QFA) to your customers?

\subsection{R\&D Development Programs}

Be sure that the development timeline for each time line is clearly mapped out and that accurate estimates are provided of the amount of time personnel will be investing in development activities. 


\section{STEP 4: MARKET STRATEGIES}

\section{I Marketing goals and objectives}

In this section you should establish specific goals and strategies for each of the following:

(1) Sales of specific products or technologies

(2) Sales to specific customer segments

(3) Sales by distribution channel

In formulating goals keep a 3-5 year time horizon in mind. Objectives are 1-2 years and indicate how much, by whom, and by when.

It is to be understood throughout this discussion that the term customer refers to the entity which is purchasing what you are selling. What you have for sale may include a license to intellectual property, R\&D work done under contract, a percentage of the company sold in exchange for funds, or a product.

Goals and objectives should reflect acknowledged needs in the market place, as well as the purchasing behavior of targeted customer segments, and your ability to close sales. In other words, when you project sales of a specific product or technology, it must reflect if there is a perceived need in the market place, the availability of customer funds, the sell cycle, and the costs associated with selling.

\subsection{Develop Marketing/Sales Projections}

It is important that you begin to look at anticipated orders, sales, margins and expenses from your sales/marketing efforts. Keep in mind that even if what you are selling is a licensing opportunity, this is a sales situation with associated marketing expenses, such as phone calls, site visits, presentation materials, etc. Consider such items when calculating the following items: (Make your calculations by month for the next year and by quarter for the ensuing years.)

(1) Quarterly and annual sales objectives, reflecting product mix and customers

(2) Quarterly and annual sales objectives and product/service pricing. (Also include the projected royalty stream from licensed technology/products.)

(3) Estimates of marketing and sales expenses reflecting promotion, advertising, and distribution costs. ( Looking for investors in your company is a sales effort and has associated costs.) Don't guess at these prices. Call local vendors and ask them how much it would cost to produce various items that you might anticipate using. If you don't have anything prepared take them a competitor's publicity piece. Tell them that you are anticipating producing something akin to this. Could they tell you the cost in quantities of $500,1,000,2,000,3,000$, and the like. It is important that you begin to get a true feeling for marketing expenses.

Some reality checks to consider throughout are:

1. sell cycle

2. expense associated with making sales

3. how many people will be reguired to make the desired sales 


\section{STEP 5: MANUFACTURING STRATEGY}

\subsection{Scaling Up}

Companies that wish to scale up for manufacturing will have the challenge of shifting from hand made, custom items to mass production. This should be done in stages that reflect the anticipated demand in the market place. The production strategy must fit with sales objectives like a hand in a glove.

Strategic items to consider in scaling up include:

(1) Customer satisfaction

(2) Use of concurrent engineering concepts

(3) Subcontracting parts of the production process or gearing up to manufacture yourself

(4) Various methods of increasing production output and thereby decreasing costs

(5) Relocation, as a means of decreasing shipping and labor costs

(6) Increasing efficiency as a means of bringing down the costs of production

In developing your production strategy you tinust concurrently consider ways to minimize production/service costs, maintain high quality, and maximize the contribution margins to the firm.

\subsection{Formulate manufacturing goals, objectives, strategies, and programs}

Having considered various options, formulate production goals, objectives, and strategies which reflect expected sales over time.

\subsection{Forecast expenses}

Forecast your expenses by month for the next two years, assuring that costs for all items are adequately reflected. Refer to page 106.

\section{STEP 6: SWOTT REVISITED}

\section{I What's the competition doing?}

You are beginning to formulate ideas regarding the rate at which you will scale up to meet the opportunity that you see. However, it is important to look at the intelligence you have been able to gather on your competitors and examine the implications for your plan. This operational plan will not unfold in a vacuum, but in a highly volatile marketplace.

Compile the information that you have available on your competitors (within your technology and competitive technologies of significance), using the matrix represented in Table 35. Have product literature, annual reports, $10 \mathrm{k}$ 's etc. handy so that you can review this as a team. Each of you will see different things in the materials. The combined perspective of all of you is important. Summarize your findings in an environmental analysis chart (See Table 36). Include a table of this nature in your business plan. 
Table 35: Competitive analysis

\begin{tabular}{|c|c|c|c|c|c|c|}
\hline 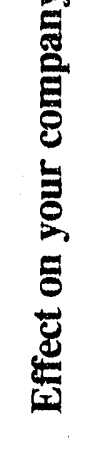 & 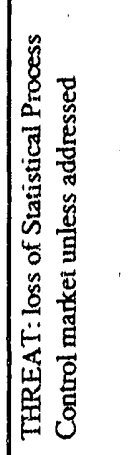 & 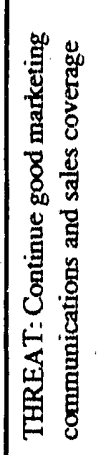 & 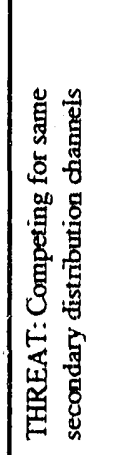 & 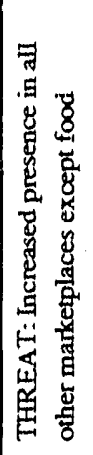 & 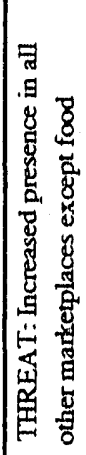 & 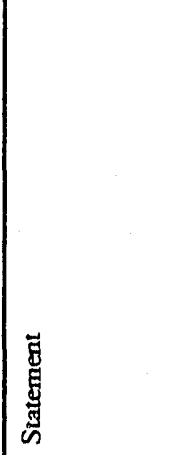 \\
\hline 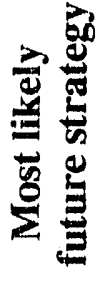 & 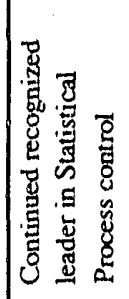 & 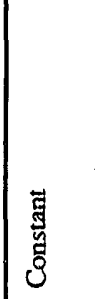 & 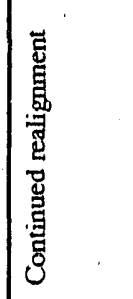 & 总 & 㞭 & 兑 \\
\hline 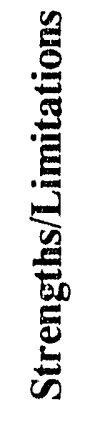 & & 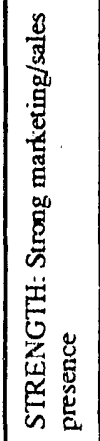 & 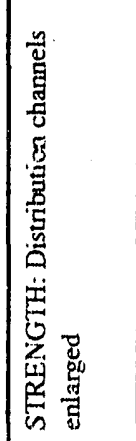 & 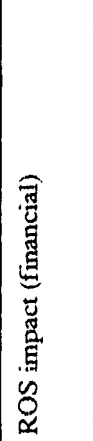 & 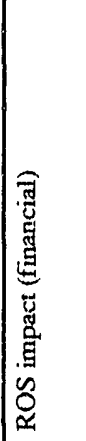 & 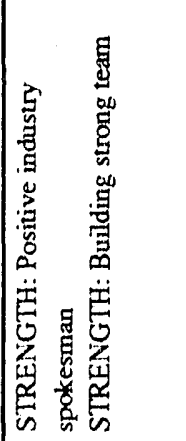 \\
\hline$\underset{\Xi}{\Xi}$ & 鸢 & 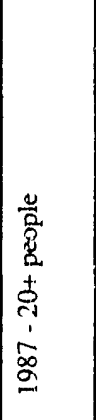 & 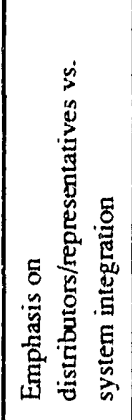 & 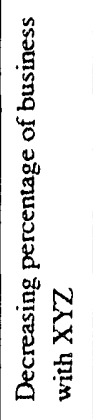 & 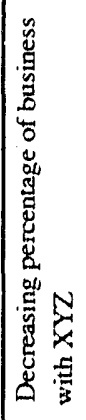 & 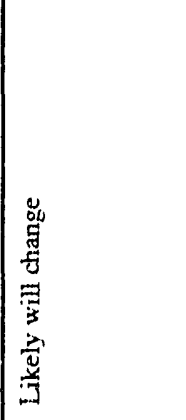 \\
\hline$\stackrel{5}{\tilde{H}}$ & 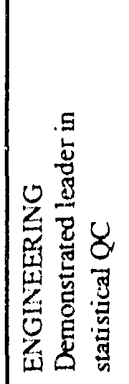 & 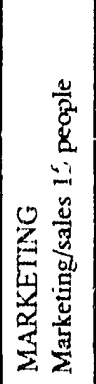 & 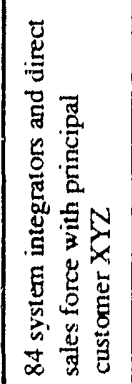 & 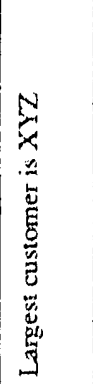 & 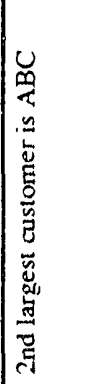 & 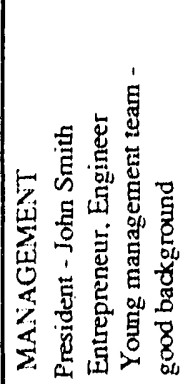 \\
\hline
\end{tabular}


Table 35: Competitive analysis (continued)

\begin{tabular}{|c|c|c|c|c|c|c|c|c|}
\hline 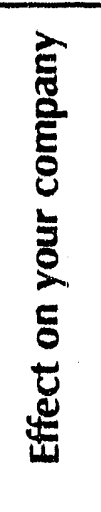 & 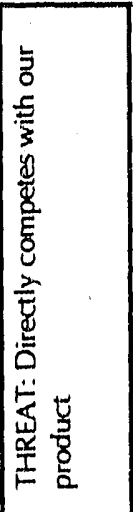 & 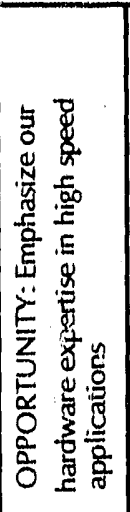 & 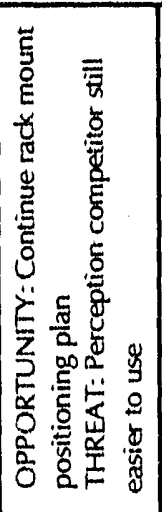 & 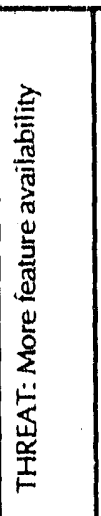 & 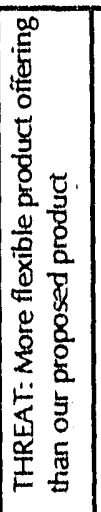 & 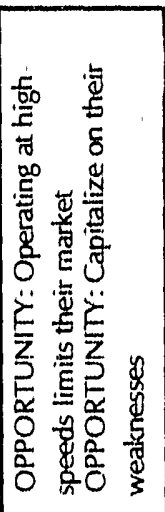 & 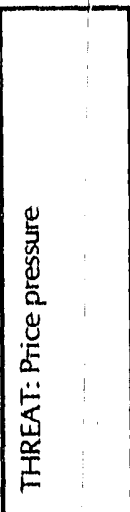 & 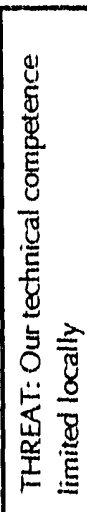 \\
\hline 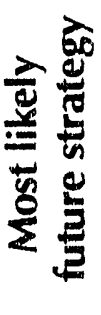 & 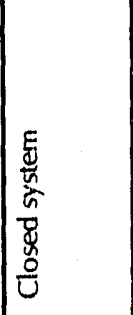 & 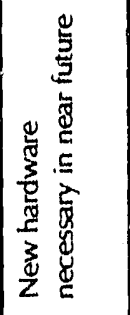 & 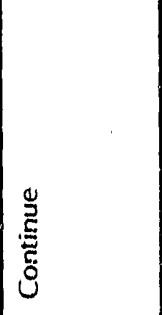 & 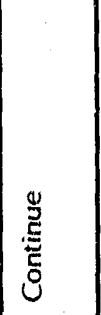 & 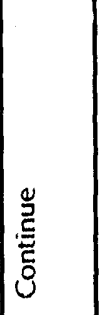 & 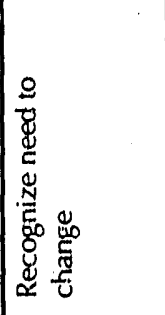 & 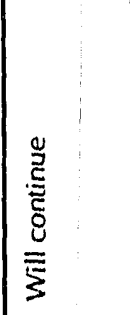 & \\
\hline & 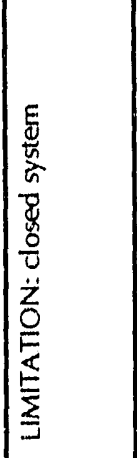 & 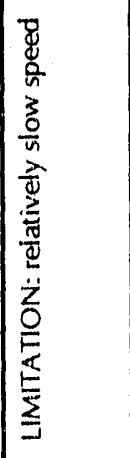 & 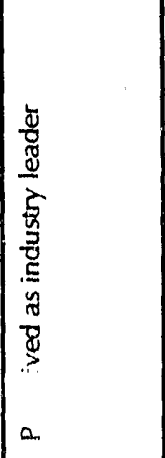 & 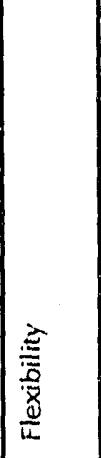 & 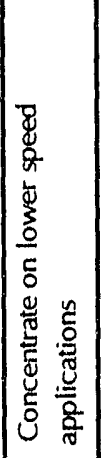 & & 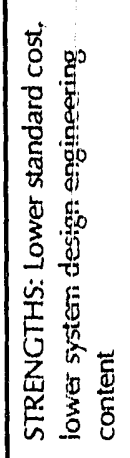 & 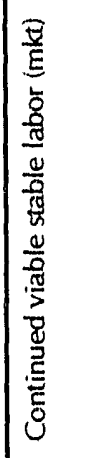 \\
\hline 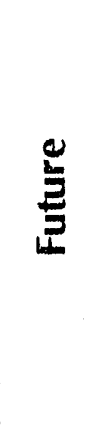 & 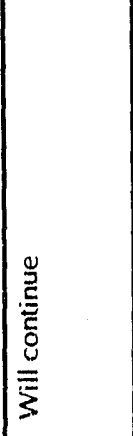 & 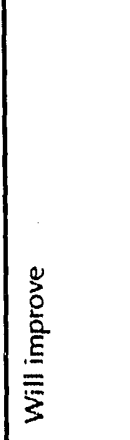 & 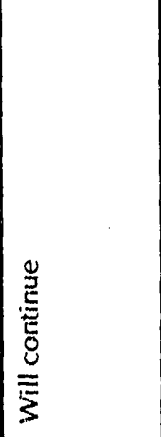 & 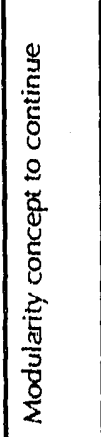 & 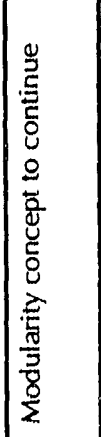 & & 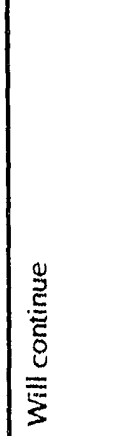 & 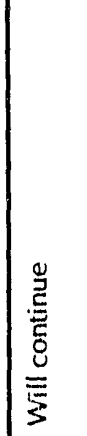 \\
\hline 苛 & 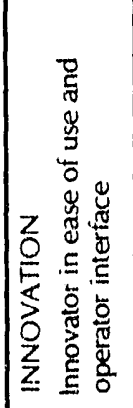 & 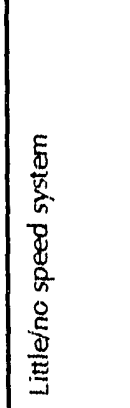 & 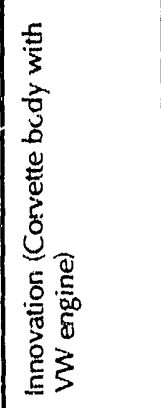 & 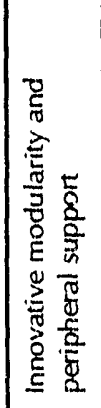 & 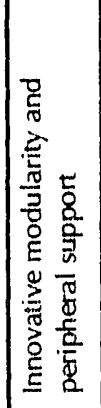 & 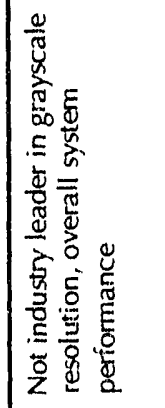 & 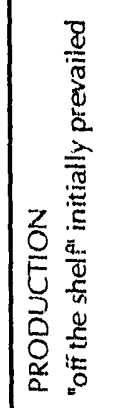 & 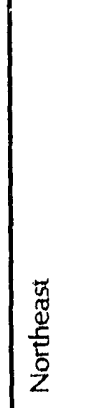 \\
\hline
\end{tabular}


Table 36: Environmental analysis

\begin{tabular}{|c|c|c|c|c|c|c|c|c|c|c|}
\hline 苞 & 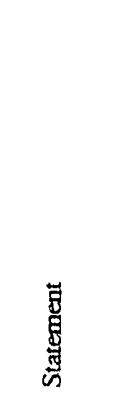 & $\begin{array}{l}\text { 苟 } \\
\text { 易 }\end{array}$ & 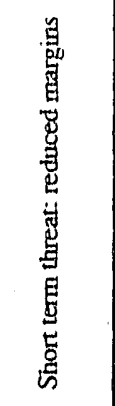 & 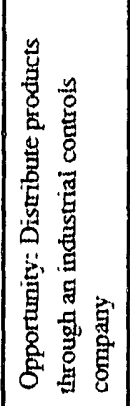 & 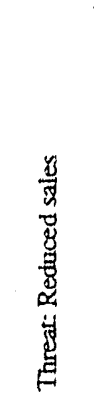 & 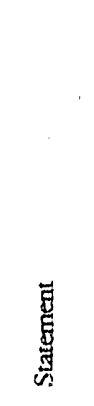 & 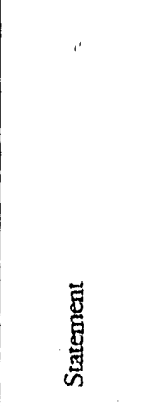 & 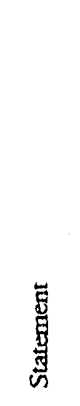 & 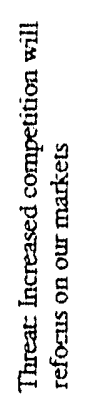 & 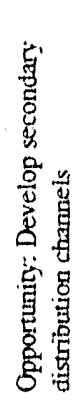 \\
\hline 额 & 总 & 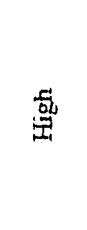 & 鵅 & $\begin{array}{l}\text { 息 } \\
\text { 焉 }\end{array}$ & 悬 & 哥 & 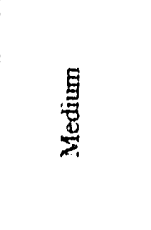 & 㚜 & 惑 & 点 \\
\hline 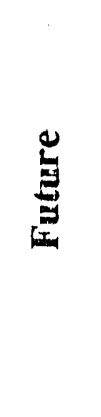 & 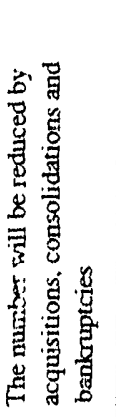 & 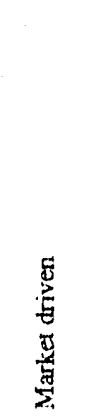 & 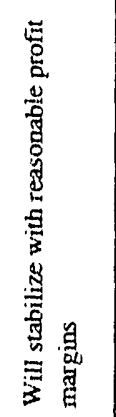 & 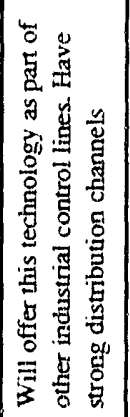 & 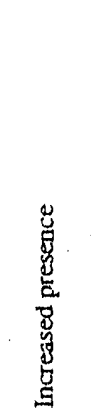 & 㞻 & 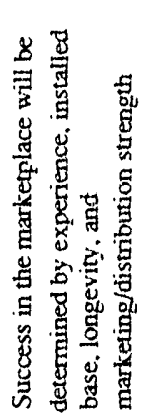 & 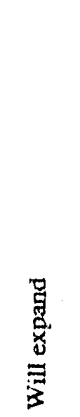 & 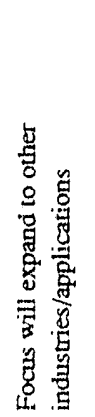 & 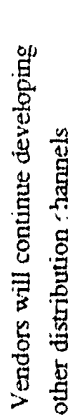 \\
\hline$\vec{y}$ & 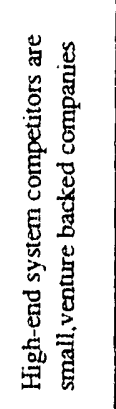 & 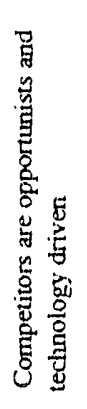 & 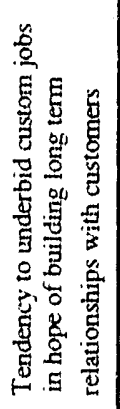 & 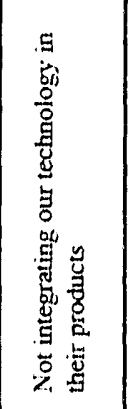 & 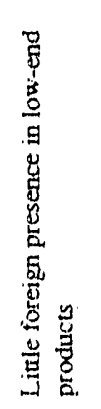 & 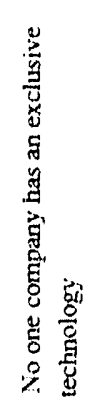 & 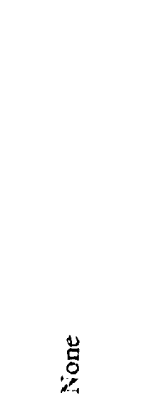 & 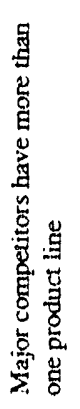 & 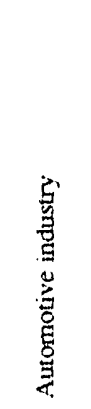 & 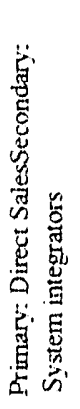 \\
\hline$\underset{\square}{\stackrel{\Xi}{\Xi}}$ & 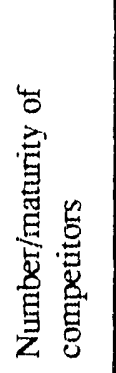 & 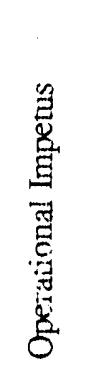 & 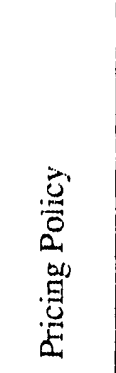 & 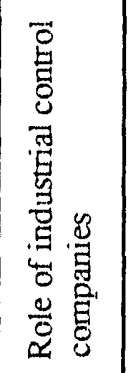 & 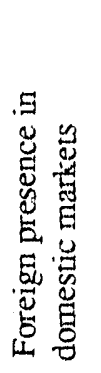 & 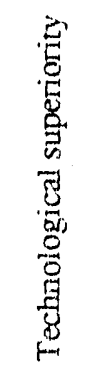 & 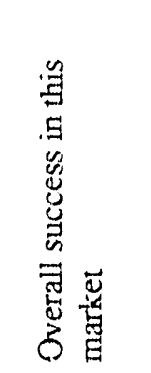 & 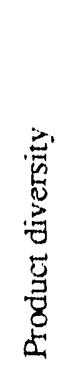 & 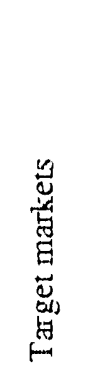 & 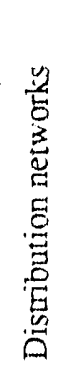 \\
\hline
\end{tabular}




\subsection{Contingency Planning}

Now that you have looked again at your competition, evaluate what actions they could take that would have an adverse effect on your strategies. Typlcal lypes of things a competitor could do include:

- drop the price

- $\quad$ provide improved service

- use a one upmanship specification strategy

- $\quad$ start an aggressive marketing campaign

- add people to their sales force

- take on key distribution channels

Assess the likelihood that your primary competitors may take some or all of these actions, and indicate what you would do to address these moves in the form of a contingency plan. Also consider if there are ways in which you can gain footing with potential customers without letting the competition know what you are up to. Remember Silver's DEJs - especially the one regarding the Invisibility of the Company (See p. 18).

\section{STEP 7: MARKET STRATEGY}

\subsection{Review goals and objectives}

In light of your competitive assessment, reconsider your marketing goals, objectives, and strategies. Should you modify these based on your review of the data or do they still seem appropriate. If they seem appropriate proceed; if they seem inappropriate modify them and make corresponding changes in your production goals, objectives, and strategies.

\subsection{Develop your marketing plan}

Your marketing plan is a very specific action plan which spells out in detailed fashion precisely what you will do to market your product/technology during the next year. Key areas to consider include:

Product: Which product/technology contributes most margin dollars to the company or which one do you believe has that capability.

Price: What should the selling price be, taking into consideration goals in terms of market share, competitor's pricing, costs of production, and desired margins. Although all of these items are to be considered, pricing is ultimately based on the maximum price the market will bear. If the price is for a technology that you are licensing, you should consider the amount for which you wish to license as well as associated terms and conditions.

Promotion/advertising: What are the activities, associated costs, and timing relative to perceived sales.

Distribution: Many companies have been formed to develop distribution channels. Distribution channels exist for most products and services. Decide which distribution channels you are going to use. Direct channels are those which your company forms; indirect are third party distributors that you use. 


\section{STEP 8: HUMAN RESOURCE PLAN}

\subsection{Human resource goals, objectives and strategles}

Begin to develop your goals, objectlves, and strategies regarding staffing. You should consider at this point what kind of incentive program you are going to have to retain your staff, Are you going to have some stock option plans? Are you golng to have perks based on hitting millestones on a timely basis?

\subsection{Manning Plan}

You will obviously need adequate staff to execute the marketing, R\&D, and production plans. In order to do this you must start by understanding the number of man-hours it presently takes to execute your existing workload. Next, extrapolate forward and estimate the number of people it will take to complete your projected work.

In areas in which you presently do not have staff' with the desired skills, do not make unverified assumptions regarding the number of hours it will take to complete their work. Instead, consult with people who fultill those roles for other companies, or with retired individuals who have played those roles previously. Ask them to give you an idea of the amount of time it takes to complete certain types of work. For R\&D firms, it will be critical to do this in the marketing, sales, and manufacturing areas. Obtain at least 3 opinions regarding required man-hours to fulfill new functions. Do not accept the input of single individuals. Begin to take a stab at writing a job description for potential new roles, so that you capture your understanding of their roles and responsibilities.

Determine the expense for hiring people in these slots. Make a decision whether your strategy will be to recruit and hire people with established skills or to hire less experienced people and train them. Both strategies have their risks. Decide which you prefer to takc.

\subsection{Estimated costs}

Begin to formulate the costs of hiring new staff. The rate at which you will project to hire staff relates to your sales, marketing, engineering, $R \& D$, manufacturing, and financial goals, objectives, and strategies.

\section{STEP 9: FINANCIAL STRATEGIES}

By this point you should have a preliminary assessment of the expense level required to grow. Now the question is how to rev up the financial engine. It is likely that your initial marketing effort - i.c. that which you will pursue for the next 6-12 months - will require that you use existing funds wisely, In other words, if your overall plan for growth is to obtain a teaming partner, venture capital, or debt equity you will need to pay for expenses associated with obtaining those arrangements out of funds that you presently have available from profit. You will therefore want to carefully husband your funds and make prudent decisions regarding the expenditure of funds.

In consideration of the funds that you have available for trying to obtain additional funds, go back once more and re-evaluate your marketing, sales, manufacturing, engineering, human resource, and R\&D goals, objectives, and strategies. Are they too ambitious during the lirst year, given your available funds. Reconfirm with members of your management team or advisers where it appears that the most likely sources of funds will come from. Examine what you can do to speed up the closing rate on pending sales.

At some point, either immediately or after you have obtained additional funds, you will have to shift to fueling your growth out of profits from sales and royalties. Carefully 
examine your profit margins. Are they sufticient to fuel sustained growth'? Because of economles of scale, your profit margins will probably start fatrity small and then increase over time as you find ways to bring down the cost of production. Increasing your profit margins should be a priorily. If you cannot see a way to increase your proflt margins over time, go back and reconsider your market segment, your means of production, and your human resource plan. Perhaps you need to re-position your product.

For example, one Dawnbreaker cllent designed a plece of specialty protectlve clothing that the inventor wished to sell to the mass market for \$30. After examining the cost of production and finding that the expenses were much higher than expected, the decision was made to re-position the product as a premium product to be sold for $\$ 80$ through high-end, specialty catalogues. Only in that fashion would the product be profitable. The market niche was correspondingly redefined.

\section{STEP 10: RE-EXAMINE YOUR COMPANY'S MISSION AND VISION}

Having gone through this process, revisit your mission statement. Is it still valid? Does it adequately describe the nature of your business? Re-examine your vision. Can it be done? Don't bother about what you have heard about the desitred rate of growth for "stars". Is the plan that you have mapped out reasonable? Can you see yourself doing this? Does it seem logical? Are you being timid, aggressive, or overly optimistic in your projections?

\section{STEP 11: WRITING THE BUSINESS PLAN}

At this point you have processed all the information that is required to write your business plan. Use the outline on pages $41-43$ to start drafting your business plan.

\section{Form}

Up unill this time, we have indicated that the format in which data are presented is unimportant. Now that you are about to draft your business plan, everything changes form becomes vital. As you draft your business plan, you should keep in mind an old Marshall MoLuhan, cliche "The medium is the message". In other words, the appearance of the document, the form in which the business plan is presented, tells the potential investor something about you. Furthermore, it affects the attitude with which he or she will read your document and makes it stand out above the hundreds of others the investor has and will see. The message that you wish to leave with the investor is that you have a technology of value; you are an excellent technologist; you are also a business person and are sensitive to market issues, design, engineering, and production costs; you have an opportunity for them to consider; and your company would be a good firm with which to work.

Some general guidelines are listed below:

- Adopt a style that you will use throughout .

- Use a type font and point that are casy to read.

- Whenever possible represent market data by use of pie charts, tables, and other figures

- Represent development time lines with Gantt and PERT charts.

- If you have too much data for some sections of the plan, include them in the Appendices. The document should read smoothly and not appear to go off on many langents.

- Make sure duplicated copies photocopy well.

- Consider the use of color. 


\section{4}

It is not possible for us to Include a copy of a completod business plan as all of those which we have developed or have assisted in developing are proprlotary. However, the guidelines that we have presented throughoui should be of assistance.

Anticipate including at least 3 appendices to your business plan:

Appendix A: Other potential applications

Appendlx B: Other: will vary depending on company

Appendix C: Detalled financials 


\section{CHAPTER 10: HOW TO USE THE BUSINESS PL.AN}

As mentloned at the outset, your businoss plan has both intemal and external valuo. As the external value is the purpose for which you have presently doveloped lints plan, we wlll discuss its axiemal applicalion lirst. Your business plan should be valid lore approxlmately one your, At the ond of that pertod, you should res"sess the situation and reviso lhe plan. Durlng this your your business plan will sorvo as a very lmportant selling docullent. However, as If oontalns very complole Information on your business, you

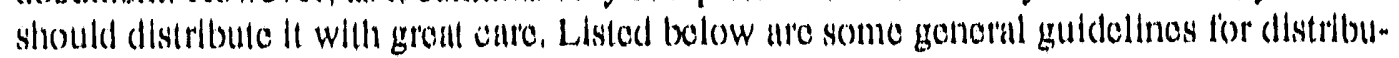
Hon:

\section{DISTRIBUTION PROTOCOLS}

(1) Do not distribute your plan to anyone who has not demonstralod a sincere Interest in your tochnologg/product, Gauge their slneerly by tho contidence and trust they engender in you, as well as by their reputation.

(2) Keep track of all your business plans by number, recordling their distribution in a log. Re(juest their retum within 30) days, Extend on an exception basis only.

(3) Clarly mark each business plan in the following mannor: Propriotary, Confldentlal, Not to be Duplicated.

(4) Ask the person to sign a conlidentlality agreement with you before sharing the business plan with them. Ask if they have any problem with this. If they do, you probably won't want to do business with thom.

Provided below is a sample confidentlalty agrecment. This is not meant to be a template, but an cxample. Please consult an attorney in drafting the one which you will use. This agreement should be the fitst itom in your business plan. 


\section{XYZ CORPORA'TION'S CONFIDENTIALITY AGREEMENT}

The information contained herein is the property of $X Y Z Z$ Corporation and is confidential. The reciplent agrees that he will not release this plan or disclose information herein, or make reproductlons or use it for any purpose other than this evaluation of a prospective investment. The recipient further agrees to return all proprietary muterials to $X Y Z$ Corporation upon request.

By signing below the reciplent acknowledges that the confldential information contains valuable concepts, of a businesis nature, of XYZ Corporation. The reciplent further acknowledges that the confidential information constitutes a trade secret of XYZ Corporation, and losis or disclositue of such confidential information will result in irreparable financial harm to XYZ Corporation.

Information in the Plan is based upon the best avallable sources at the time of writing, but should not be taken as final. In particular, the forecasted financial information is estimated based on XYZ Corporation managentent's Judgment, and actual res'ults' will vary from the information presented, and the varlations may be material. This document is not an offer to sell. nor a solicitation of an offer to buy any securities, or other interest. in any corporation or other entity. The sale of any securities in and the making of any' investment in any corporation or other entity would be solely under the terms of the applicable agreements, and subject to the laws' of the appropriate jurisdiction. 


\section{How to create opportunittes for distributing your plan}

During the development of this plan you have taken several steps "to get close to the customer." This should be an on-going activity, In the process it is likely that you will find potential teaming partners. If you are particularly impressed with a potential customer, explore if there is any interest in devoloping a relattonshlp (R\&D contract, licensing, other teaming arrangements). At this point, you are looking to create a sponsorr, If there appears to be interest, ask the potential sponsor to sign a Conlidentiality Agrecment. Although companies are reluctant to do this they do sign Confidentiality Agreements if the prospects look promising. Once this has been signed, share your business plan with them following the protocols outlined above.

If a potential sponsor is reluctant to sign a confidentiality agreement, you could provide them with an abbreviated copy of your executive summary to whet his appetite. In this case, be sure that there is no proprietary information in the Executive Summary. Once a Confidentiality Agreement has been signed, some companies exclude the complete financials (usually enclosed in an appendix) and provide only the abbreviated financials in the Financial Section of the Plan.

Although venture capital is unlikely to be a source of capital for many, it should not be overlooked by those who have a product ready to go to market. Consult Pratt's Guide to Venture Capital and find out who are the venture capitalists in your area. Look for appropriate avenues of introduction.

\section{How to know if you are making progress?}

The following steps indicate increasing interest on the part of a potentlal sponsor:

(1) Potential sponsor signs a confidentiality agreement

(2) Site visit - needs are clarified

(3) "Due diligence" - the potential sponsor does some probing at his own expense usually into the market area

(4) Another site visit.

\section{(5) Negotiations begin}

In this process you should pay particularly close attention to the objections and concerns raised by the potential sponsor. Try to formulate ways in which these could be addressed, either by R\&D or other ways. The negotiations that ensue are a clarlfication of give and take on both parts. Stay in contact and be responsive. If the negotiations end by the investor saying, "get back to me when you have addressed issue X.", be sure to do so! This type of statement is typically a "buying signal". Your response should be "If we can solve this problem, would you be interested in X?" Don't leel that because an objection was raised that the door was closed forever. Remember the potential sponsor has already invested time and money in the evaluation of the opportunity. If you can address the concerns and are persistent, you are presenting yourself as a responsive polential partner. 


\section{INTERNAL. VALUE OF THE PIAN}

The biggest mistake a company can make is to put its business plan on the sheli, once it has attempted to obtain funds. When well-developed, a business plan should act as your gulde and a rallying point for your stafi, Use it in quarterly reviows with your management toam to see how the company is track.ing. Use it as a screen to doolde if unforeseon events are opportunities or diversions. Use it to remind yourself of your pritorilies in this complex playing field.

As conditions change, and as you continue to learn about your market and how your' company is percelved, your plan will change. Just as a ship's captain adjusts course whon the winds change direction, so will you. It is therefore important to re-do your plan annually. It will seldom be as much work as it has been this time, as you will have considerable data in hand, will understand the business planning process, and will know how to go about looking for opportunities. 


\section{BIBLIOGRAPHY}

1. Baty, Gordon B. Seed Capital Funds: Financial Management Association. Unpublished Document 10/25/89.

2. Berkman, Robert. Find It Fast. New York: Harper and Row, 1990.

3. Bruce, Robert $V^{\prime}$. Alexander Graham Bell and the Conquest of Solitude. Boston: Little, Brown, and Co, 1973.

4. Cooper, Robert G. Winning at New Products. Reading, MA: Addison-Wesley Publishing Co., 1988.

5. Deloitte, Haskins and Sells. Raising Venture Capital: An Entrepreneur's Guide. 1987.

6. Deloitte, Haskins and Sells. Financing Business Growth: An Entrepreneur's Guidebook. 1988.

7. Deloitte, Haskins and Sells. R \& D Limited Partnerships. 1984.

8. Fuld, Leonard M. Monitoring the Competition: Find Out What's Really Going on Qver There. New York: John Wiely and Sons, 1988.

9. Garnet, Robert W. The Telephone Enterprise: The Evolution of the Bell System's Horizontal Structure, 1876-1909. Baltimore: The John Hopkins University Press, 1985.

10. Geringer, J. Michael. Joint Venture Partner Selection: Strategies for Developed Countries. New York: Quorum Books, 1988.

11. Gladstone, David J. Venture Capital Handbook. Reston, VA: Reston Publishing Co., 1983.

12. Gladstone, David. Venture Capital Investing: The Complete Handbook for Investing in Small Private Businesses for Outstanding Profits. Englewood Cliffs, NJ: Prentics Hall, 1988.

13. Kozmetsky, George; Gill, Michael, and Smilor, Raymond. Financing and Managing Fast Growth Companies: The Venture Capital Process. D.C. Heath and Co, 1985.

14. Makens, James. C. The Marketing Plan Workbook. New York: Prentice-Hall, 1985.

15. The Malcolm Baldridge National Quality Award Consortium, Inc. Application Guidelines: Malcolm Baldridge National Quality Award. Milwaukee, WI, 1991.

16. Mancuso, Joseph R. How to Write a Winning Business Plan. New York: Prentice Hall Press, 1985.

17. McKiernan, John. Planning and Financing Your New Business: A Guide to Venture Capital. Chestnut Hill, MA: Technology Management Inc., 1978. 
18. Merrill, Lynch, Pierce, Fenner and Smith, Inc. How to Read a Financial Report. New York: Merrill, Lynch, Pierce, Fenner and Smith, Inc., 1984.

19. Ohmae, Kenichi. The Global Logic of Strategic Alliances. Harvard Business Review, March-April, 1989, Pgs. 143-155.

20. O'Hara, Patrick D. Funding Research and Development: How to Team Up with the Federal Government to Finance your R \& D. Chicago: Probus Publishing Co., 1990.

21. Pinson, $L$ and Jinnett, J. Anatomy of a Business Plan. Fullerton, CA: Out of Your Mind... and into the Marketplace, 1991.

22. Silver, A. David. Who's Who of Venture Capital. New York: John Wiley and Sons, 1984 and 1988.

23. Skousen, K. Fred. An Introduction to the SEC. Cincinnati: South Western Publishing Co. 1991.

24. Smith, George David. The Anatomy of a Business Strategy: Bell, Western Electric and the Origins of the American Telephone Industry. Baltimore: The John Hopkins University Press, 1985.

25. Speser, Philip. SBIR Commercialization Manual. Germantown, MD: Department of Energy, 1988.

26. Sutton, David and William Benedetto. Initial Public Offerings: A Strategic Planner for Raising Equity Capital.Chicago: Probus Publishing Co, 1988.

27. Taylor, James W. Competitive Marketing Strategies: An action plan for achieving market leadership. Radnor, PA: Chilton Book Co., 1986.

28. Thomsett, Michael C. The Little Black Book of Project Management. Amacom, 1990. 


\section{APPENDIX A}

\section{VENTURE CAPITAL. FIRMS THAT PROVIDE SEED MONEY}

Ampersand Ventures

55 William St.

Suite 240

Wellesley, MA 02181

617-239-0700

Fax: 617-239-0824

American Research and Development, Inc. 45 Milk St.

Seventh Floor

Boston, MA 02 109-5173

617-423-7500

Fax:617-423-9655

Greylock Management Corp.

One Federal St.

Boston, MA 02110

617-423-5525

Fax: 415-328-4725

Menlo Ventures 3600 Sand Hill Rd.

Building Four, Suite 100

Menlo Park, CA 94025

415-854-8540

Fax: 415-854-7059

Sutter Hill Ventures

755 Page Mill Rd.

Suite A-200

Palo Alto, CA 94304

415-493-5600

Fax: $415-858-1854$

Technology Venture Investors

3000 Sand Hill Rd.

Bldg. 4, Suite 210

Menlo Park, CA 94025

415-854-7472

Fax: $415-854-4187$
Preferred Investment: $\$ 1-\$ 2.5$ million

Capital Under Management: $\$ 100$ million

Preferred Investment: $\$ 500,000$ - $\$ 1$ million Capital Under Management: $\$ 80$ million Contact: Maureen A. Nilson, Adm. Manager Management: Charles J. Coulter, Mng. Gen. P.

Preferred Investment: Over $\$ 1$ million Capital Under Management: over $\$ 200$ million Contacts: William W. Heiman, Ptnr.

William S. Kaiser

Preferred Investment: Over \$1 million Capital Under Management: \$275 million Thomas H. Bredt: General partner Ken E. Joy: General Partner

Preferred Investment: Over $\$ 1$ million Capital Under Management: Over $\$ 100$ million Mngt: Paul M. Wythes, General Partner Tench Coxe, General Partner

Preferred Investment: Over \$1 million Capital Under Management: $\$ 270$ million Mngt: John R. Johnston, General Partner Mark Wilson, General Partner 
Venrock Associates

30 Rockerfeller Plaza

Suite 5508

New York, NY 10112

212-649-5600

Fax: $212 \cdot 649-5788$

Zero Stage Capital Co., Inc.

One Broadway

10th Floor

Cambridge, MA 02.142

617-876-5355

Fax: 617-876-1248
Preferred Investment: $\$ 500,000-\$ 1$ million Capital Under Management: $\$ 160$ million Mngt. Peter O. Crisp, General Partner (NY)

Anthony Sun, General Partner (Palo Alto)

Preferred Investment: $\$ 250,000-\$ 500,000$ Capital Under Management: $\$ 40$ million Mngt.: Gordon B. Baty, Mng. Gen. Pinr. Barbara A. Panholt, Mng. Gen. Ptnr. 


\section{INDEX}

Ampersand Ventures, 21

Anatomy of a Business Plan, 124

Burriers to entry, 121

Book of Lists, 98

Bridge finuncing, 19

Business angel, 22

Business Planning, 39-51

Cash flow analysis, 130

Cash-oul, 24

CASSIS, CD-ROM, 95

Chumpions, 5,6,8

Conlition building, 5

Commerce, US Department of, 85

Commercialization, 1,4

Commercialization team, 5,8

Competitive analysis, 138

Competitive Marketing Strategies, 83

Confidentiality Agreement, 29

Corporale venturing, 23

Customers $15-18,65,82$

DEJ 18

Dawnbreaker Business Planning Process, 45

DIALOG, 8,87,91

Direcel sales, 98

Directory of Converuions, 8

Directory of Manufacturer's Sales Agencies, 118

Disclosures, 29

Distribution channels, 98, 118

Distribution of business plan protocols, 145

Due diligenee, 20

\section{8-K, 31}

Early stage financing, 19

Encyclopedia of Associations, 8, 85

End-user, 65

Environmental analysis, 140

Equity investment, 18

Equity partnership, 34

Everybody's Business, 31

Evolutionary innovations, 54

Expansion financing, 19

Exploitation, 1,4

FAB, 113

Financial strategies, 142

Find It Fast, 31

Findex: The Directory of Market Research Reports, Studies, and Surveys, 87

First stage financing, 19

Gale Directory of Publications and Broadcast Media, 90

Gatekeepers, 5

"Going public", 24

"Grizzly principle", 39

High-Tech Directory, 91

Human resource strategy, 142 
IPO, 25

Initial Public Oflering. 25

Initial Public Offerings: A Strategic: Planner for Raising Equity Caplial, 24)

Innovation, 53

International Trade Administration, 85

International Trade Commission, 85

Inventors, 5

Joint venture, 32-34

Key customer sules unalysis, 130

Licensing, 28-.31

Licensing Executive Society, 9

Limited partnership, 35

Manufacturing strategy, 137

Market segmentation, 2

Market size, 87-89

Market strategies, 136, 141

Marketing/Distribution Agreement, 26

Marketing/Sules Projections, 136

Menlo Ventures, 21

Mind map, 55

Mission, 84

Monitoring the Competition, 93

Moody's Manuals, 10

NIH, 10

New Product Development, 112

Non-Disclosure Agreement, 29

Not Invented Here, 10

Option to Liconse, 30

Palent It Yourself, 28

Pratt's Guide to Venture Capital Sources, 19

Product development, 1,2,4

Public Offering, 19

R\&D Limited Partnership, 34-35

ROI, 6,24

Raising Venture Capital, 124

Research/Development Agreement, 26

Return on Investment, 6

Royalties, 30

Royaily Partnership, 34

SBDC., 50

SCORE, 50, 63

SEC, 25

SIC, 78

SWOTT Analysis, 1.3.3

Second Stage Financing, 19

Secrecy Agreement, 29

Securities and Exchange Commission, 25,31

Seed Financing, 19

Segmenting the market, 83

Selected Dissemination of Information, 8

Served available market, 88

Size of the Market, 87-89

Small Business Development Centers, 50 
Sponsors, 5,6,8,9

Stakeholders, 5,7,76

Standard and Poor's Register of Corporations, 10

Standard Industrial Code, 78

Standard Periodical Directory, 90

Start-Up Financing, 19

Strategic Alliance, 26-27

Submitted Ideas Office, 9

Sustuinable Competitive Advantage, 68

$10-\mathrm{K}, 31$

$10-\mathrm{Q}, 31$

Technology Access, 28

Technology development, 1

Technology Venture Investors, 21

Third Stage Financing, 19

Thomas Register of American Manufacturers, 91

Total market, 88

United States Industrial Outlook, 85

Valuation, 23

Venrock Associates, 21

Venture Capital Handbook, 24

Venture Capitalists, 18-22

Venture Capital Investing: The Complete Handbook for Investing in Small Private Businesses for Outstand. ing Profit, 48

Vision, 70

Ward's Business Directory of US Private and Public Companies, 91

Washington Legislative Information, 96

Who's Who of Venture Capital, 18

Winning at New Products, 64

Writing the business plan, 143

Zero Stage Capital, 21 

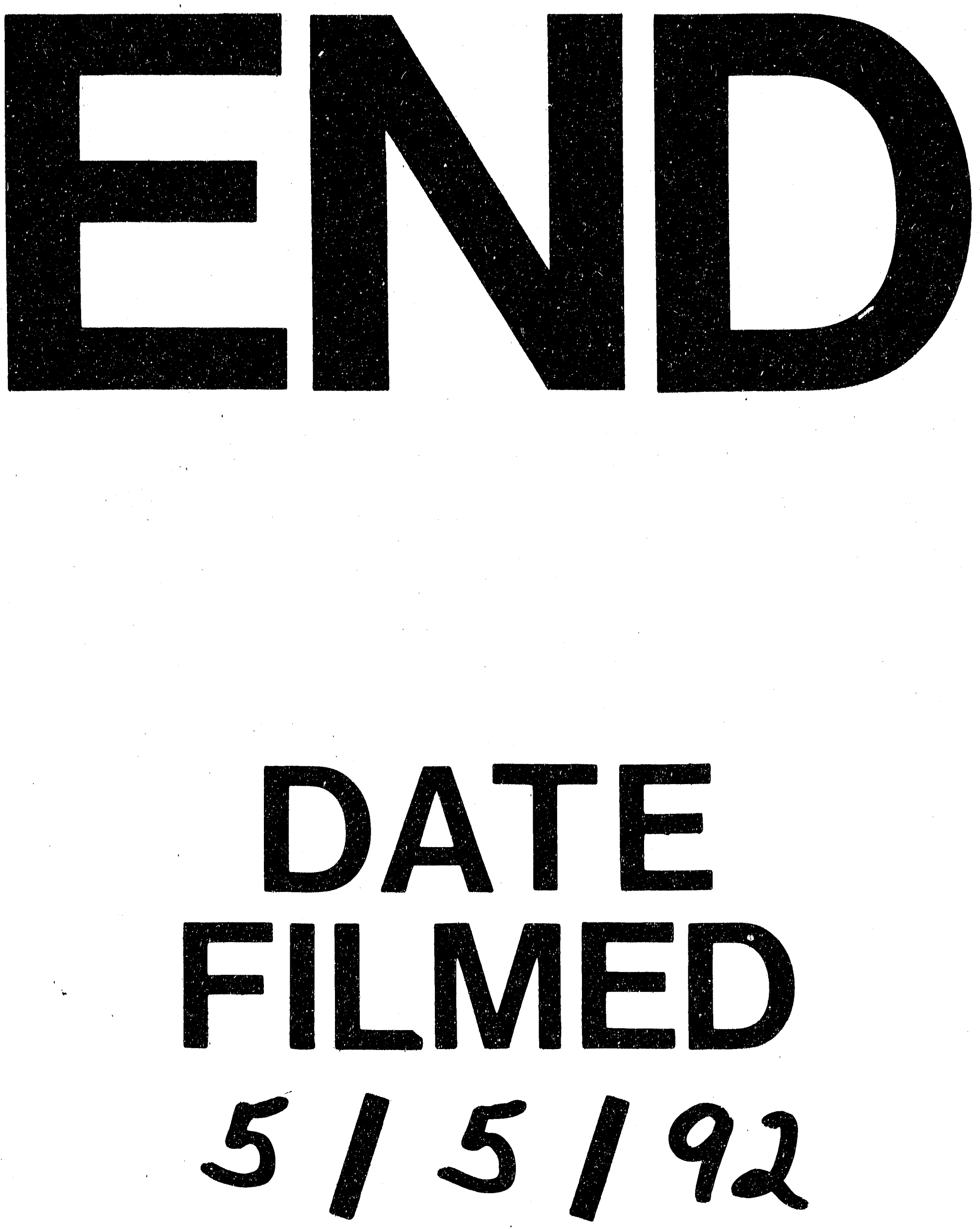

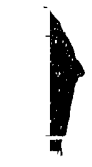




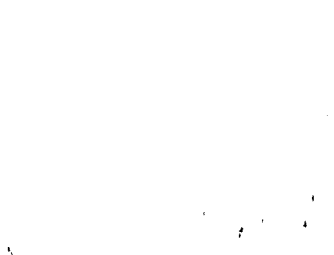

